University of South Florida

DIGITAL COMMONS

Digital Commons @ University of

@ UNIVERSITY OF SOUTH FLORIDA

South Florida

June 2018

\title{
Environmental controls on the geochemistry of Globorotalia truncatulinoides in the Gulf of Mexico: Implications for paleoceanographic reconstructions
}

Caitlin Elizabeth Reynolds

University of South Florida, creynolds@usgs.gov

Follow this and additional works at: https://digitalcommons.usf.edu/etd

Part of the Geology Commons

\section{Scholar Commons Citation}

Reynolds, Caitlin Elizabeth, "Environmental controls on the geochemistry of Globorotalia truncatulinoides in the Gulf of Mexico: Implications for paleoceanographic reconstructions" (2018). USF Tampa Graduate Theses and Dissertations.

https://digitalcommons.usf.edu/etd/7355

This Thesis is brought to you for free and open access by the USF Graduate Theses and Dissertations at Digital Commons @ University of South Florida. It has been accepted for inclusion in USF Tampa Graduate Theses and Dissertations by an authorized administrator of Digital Commons @ University of South Florida. For more information, please contact digitalcommons@usf.edu. 
Environmental controls on the geochemistry of Globorotalia truncatulinoides in the Gulf of Mexico: Implications for paleoceanographic reconstructions

by

\title{
Caitlin Elizabeth Reynolds
}

\author{
A thesis submitted in partial fulfillment \\ of the requirements for the degree of \\ Master of Science in Marine Science \\ with a concentration in Geological Oceanography \\ College of Marine Science \\ University of South Florida
}

Major Professor: Brad E. Rosenheim, Ph.D.

Julie N. Richey, Ph.D.

Amelia E. Shevenell, Ph.D.

Date of Approval:

June 6, 2018

Keywords: Globorotalia truncatulinoides, Gulf of Mexico, Laser ablation, $\mathrm{Mg} / \mathrm{Ca}$, Planktic foraminifer, Sediment trap

Copyright (@ 2018, Caitlin E. Reynolds 


\section{ACKNOWLEDGEMENTS}

First and foremost, I would like to thank my husband Alex M. Reynolds and our daughter Olivia Lane. It would have been impossible to accomplish all I had without your love and support.

Secondly, my career would not be where it is today without Dr. Richard Z. Poore. Dick encouraged me to go back to school and helped facilitate furthering my education. What he has taught me throughout my scientific career is insurmountable. I would like to also thank Dr. Julie N. Richey, who is not only my committee member and my USGS supervisor, but a tremendous lifelong friend. She is a strong, supportive mentor I truly look up to and admire. She has allowed me to grow as a scientist in both expertise and experiences and for that I am forever grateful. I also thank committee members Dr. Brad E. Roesnheim (major advisor) and Dr. Amelia E. Shevenell. I am appreciative for your guidance, new perspectives, and help throughout the process of completing this work.

Third, I would like to thank Eric Tappa, Dr. Kaustubh Thirumalai, and the LUMCON crew of the RV Pelican for ongoing maintenance of the sediment trap mooring. Thanks to Dr.

Jennifer S. Fehrenbacher and Dr. Howard J. Spero for help with the manuscript publication, I am appreciative for all of your direction and support. I also need to thank my forever officemate, Jennifer A. Flannery, not only for your laboratory proficiency, but your constant enthusiasm and encouragement.

Last but not least, I thank my parents, Thomas and Dena Nay. Your love and inspiration has always been the driver to pursuing my dreams as a geologist. 


\section{TABLE OF CONTENTS}

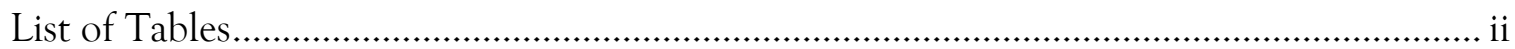

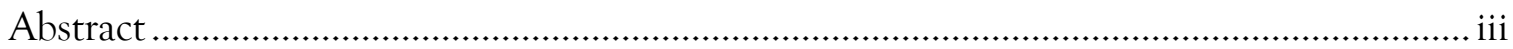

Chapter One: Environmental controls on the geochemistry of Globorotalia truncatulinoides in the Gulf of Mexico: Implications for paleoceanographic

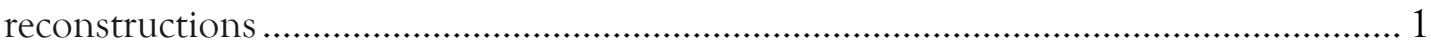

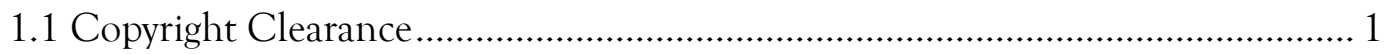

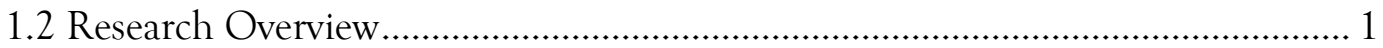

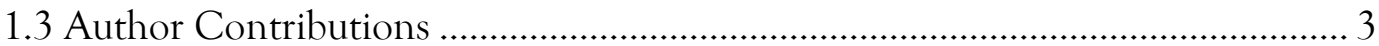

Appendix A: Environmental controls on the geochemistry of Globorotalia truncatulinoides in the Gulf of Mexico: Implications for paleoceanographic reconstructions

Appendix B. Environmental controls on the geochemistry of Globorotalia truncatulinoides in the Gulf of Mexico: Implications for paleoceanographic

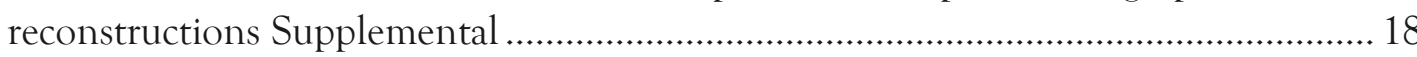

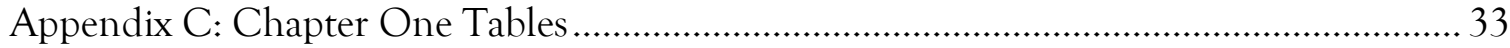

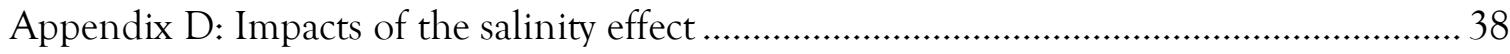




\section{LIST OF TABLES}

Table C.1 Non-encrusted and encrusted depth ranges and averages ............................ 33

Table C.2 Encrusted homogenous zone $\mathrm{Mg} / \mathrm{Ca}$ determinations.................................... 34

Table C.3 Non-encrusted and encrusted sample morphometrics, geochemical,

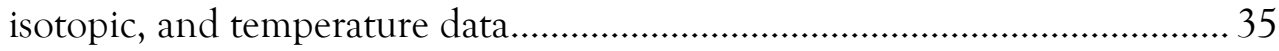




\begin{abstract}
Modern observations of planktic foraminifera from sediment trap studies help to constrain the regional ecology of paleoceanographically valuable species. Results from a weekly-resolved sediment trap time series (2008-2014) in the northern Gulf of Mexico demonstrate that 92\% of Globorotalia truncatulinoides flux occurs in winter (January, February, and March), and that encrusted and non-encrusted individuals represent calcification in distinct depth habitats. We use individual foraminiferal analysis (IFA) of G. truncatulinoides tests to investigate differences in the elemental $(\mathrm{Mg} / \mathrm{Ca})$ and isotopic composition $\left(\delta^{18} \mathrm{O}\right.$ and $\left.\delta^{13} \mathrm{C}\right)$ of the encrusted and non-encrusted ontogenetic forms of G. truncatulinoides, and to estimate their calcification depth in the northern Gulf of Mexico. We estimate that non-encrusted and encrusted G. truncatulinoides have mean calcification depths of $66 \pm 9$ meters and $379 \pm 76$ meters, respectively. We validate the $\mathrm{Mg} / \mathrm{Ca}$ calcification temperature relationship for G. truncatulinoides and demonstrate that the $\delta^{18} \mathrm{O}$ and $\mathrm{Mg} / \mathrm{Ca}$ of the non-encrusted form is a suitable proxy for winter surface mixed layer conditions in the Gulf of Mexico. Care should be taken not to combine encrusted and non-encrusted individuals of G. truncatulinoides for down core paleoceanographic studies.
\end{abstract}




\section{CHAPTER ONE:}

\section{ENVIRONMENTAL CONTROLS ON THE GEOCHEMISTRY OF GLOBOROTALIA TRUNCATULINOIDES IN THE GULF OF MEXICO: IMPLICATIONS FOR PALEOCEANOGRAPHIC RECONSTRUCTIONS}

\subsection{COPYRIGHT CLEARANCE}

Appendix A: Environmental controls on the geochemistry of Globorotalia truncatulinoides in the Gulf of Mexico: Implications for paleoceanographic reconstructions, presents work previously published in the journal Marine Micropaleontology, published by Elsevier. DOI: 10.1016/j.marmicro.2018.05.006. A complete reprint is provided with the authors' permission in Appendix A. (C) 2018 CE Reynolds; Richey, JN; Fehrenbacher, JS; Rosenheim, BE; Spero, HJ. I retain or am hereby granted (without the need to obtain further permission) the Author Rights from Elsevier. The Author Rights include the right to use the Preprint, Accepted Manuscript and the Published Journal Article for Personal Use and Internal Institutional Use.

\subsection{RESEARCH OVERVIEW}

Here we present paired isotopic $\left(\delta^{13} \mathrm{C}\right.$ and $\left.\delta^{18} \mathrm{O}\right)$ and $\mathrm{Mg} / \mathrm{Ca}$ data obtained from individual Globorotalia truncatulinoides specimens from a weekly-resolved sediment trap time series in the nGoM. Using this approach, we are able to take a detailed investigation of the geochemical differences between encrusted and non-encrusted forms. We use this information to (1) validate 
the $\mathrm{Mg} / \mathrm{Ca}$-calcification temperature relationship for $\mathrm{G}$. truncatulinoides, (2) demonstrate that the non-encrusted form calcifies in the surface mixed layer, whereas the crust forms well below the seasonal thermocline, and (3) demonstrate that LA-ICP-MS analyses of single foraminifera can be used to yield comparable elemental ratios to that obtained from solution-based analyses.

Using the geochemistry of individual foraminifera from a sediment trap time series in the northern Gulf of Mexico (GoM), we determined that the encrusted (C) and non-encrusted (NC) forms of Globorotalia truncatulinoides calcify in distinct depth habitats in the upper ocean. If care is taken to discriminate between the two forms for down core studies, the non-encrusted form can be used to reconstruct winter surface mixed layer conditions in the GoM. Oxygen isotopes of individual foraminifera indicate a mean calcification depth for NC G. truncatulinoides of $66( \pm 9)$ meters, within the surface mixed layer. The mean depth represented by encrusted specimens is 379 $( \pm 76)$ meters, assuming $29 \%$ of the calcite of an encrusted specimen originates in the winter mixed layer.

Laser ablation laser ablation inductively coupled plasma mass spectrometry (LA-ICP-MS) $\mathrm{Mg} / \mathrm{Ca}$ values based on the weighted mean for an individual foraminifer are not significantly different from solution-based $\mathrm{Mg} / \mathrm{Ca}, 2.75 \pm 0.56 \mathrm{mmol} / \mathrm{mol}$ and $3.01 \pm 0.30 \mathrm{mmol} / \mathrm{mol}$, respectively. When using LA-ICP-MS, the weighted mean of the final three chambers (F, F1, and F2) is an acceptable method for approximating the $\mathrm{Mg} / \mathrm{Ca}$ of a whole foraminifer test. $\mathrm{NC} \mathrm{G}$. truncatulinoides have a flux-weighted temperature $21.3^{\circ} \pm 3.4^{\circ} \mathrm{C}$ using Anand et al., 2003 (ten 
planktonic species) equation, which is identical to the $0-150$ meter flux-weighted temperature at the sediment trap site $\left(21.3 \pm 3.3^{\circ} \mathrm{C}\right)$ from CTD observations.

\subsection{AUTHOR CONTRIBUTIONS}

CER and JNR contributed equally to the conception of this work. All data was collected by CER and JNR and analyzed by CER. All authors discussed the results and their implications. CER wrote the manuscript and compiled all tables, figures, and supplemental information. All authors commented on the manuscript throughout the preparation process. 
APPENDIX A: ENVIRONMENTAL CONTROLS ON THE GEOCHEMISTRY OF

GLOBOROTALIA TRUNCATULINOIDES IN THE GULF OF MEXICO: IMPLICATIONS

FOR PALEOCEANOGRAPHIC RECONSTRUCTIONS 


\section{ARTICLE IN PRESS}

Marine Micropaleontology $\mathrm{xxx}(\mathrm{xxxx}) \mathrm{xxx}-\mathrm{xxx}$

Contents lists available at ScienceDirect

Marine Micropaleontology

journal homepage: www.elsevier.com/locate/marmicro

Research paper

Environmental controls on the geochemistry of Globorotalia truncatulinoides in the Gulf of Mexico: Implications for paleoceanographic reconstructions

Caitlin E. Reynolds $^{\mathrm{a}, \mathrm{b}, *}$, Julie N. Richey ${ }^{\mathrm{a}}$, Jennifer S. Fehrenbacher ${ }^{\mathrm{c}}$, Brad E. Rosenheim ${ }^{\mathrm{b}}$, Howard J. Spero ${ }^{\mathrm{d}}$

a U.S. Geological Survey, St. Petersburg, FL 33701, USA

'College of Marine Science, University of South Florida, St. Petershurg, FL 33701, USA

${ }^{c}$ College of Earth, Ocean and Atmospheric Sciences, Oregon State University, Corvaltis, OR 97331, USA

a Department of Earth and Planetary Sciences, University of California Davis, Davis, CA 95616, USA

A R T I C L E IN F O

Keywords:

Globorotalia truncatulinoides

Gulf of Mexico

$\mathrm{Laser}$ ab
$\mathrm{Mg} / \mathrm{Ca}$
Planktic

Planktic foraminifer

Sediment trap

\begin{abstract}
A B S T R A C T
Modern observations of planktic foraminifera from sediment trap studies help to constrain the regional ecology of paleoceanographically valuable species. Results from a weekly-resolved sediment trap time series (2008-2014) in the northern Gulf of Mexico demonstrate that $92 \%$ of Globorotalia truncatulinoides flux occurs in winter (January, February, and March), and that encrusted and non-encrusted individuals represent calcification in distinct depth habitats. We use individual foraminiferal analysis (IFA) of $G$. truncatulinoides tests to investigate differences in the elemental $(\mathrm{Mg} / \mathrm{Ca})$ and isotopic composition $\left(\delta^{18} \mathrm{O}\right.$ and $\left.\delta^{13} \mathrm{C}\right)$ of the encrusted and non-encrusted ontogenetic forms of $G$. truncatulinoides, and to estimate their calcification depth in the northern Gulf of Mexico. We estimate that non-encrusted and encrusted G. truncatulinoides have mean calcification depths of $66 \pm 9 \mathrm{~m}$ and $379 \pm 76 \mathrm{~m}$, respectively. We validate the $\mathrm{Mg} / \mathrm{Ca}$-calcification temperature relationship for $G$. truncatulinoides and demonstrate that the $\delta^{18} \mathrm{O}$ and $\mathrm{Mg} / \mathrm{Ca}$ of the non-encrusted form is a suitable proxy for winter surface mixed layer conditions in the Gulf of Mexico. Care should be taken not to combine encrusted and non-encrusted individuals of $G$. truncatulinoides for down core paleoceanographic studies.
\end{abstract}

\section{Introduction}

The most widely used sedimentary paleoceanographic proxies for sea-surface temperture (SST) in the subtropical Atlantic Ocean (e.g., Globigerinoides ruber $\mathrm{Mg} / \mathrm{Ca}, \mathrm{TEX}_{86}$ and $\mathrm{U}_{37}^{K^{\prime}}$ ) have been shown to reflect mean annual surface conditions in the northern Gulf of Mexico (nGoM) (Richey et al., 2007; Richey and Tierney, 2016). Whereas seasonal biases in proxy recorders can present problems for paleoclimate reconstructions (Schmidt et al., 2006), exploiting well-defined ecological differences (i.e., seasonal or depth habitat) between different proxy recorders can be used to better understand seasonality or water column structure changes in the paleoceanographic record. Previously published nGoM sediment trap time series data demonstrate that the asymbiotic, non-spinose bearing planktic foraminifer, Globorotalia truncatulinoides, is exported from the water column nearly exclusively in the winter (Spear et al., 2011; Poore et al., 2013; Reynolds and Richey, 2016). A well-constrained winter proxy (not just a winter-biased proxy) will help discern how changes in seasonality play into past climatic events in the nGoM, and provide insights into the oceanographic response to both forced and internal climate variability.

Globorotalia truncatulinoides has most commonly been interpreted as a deep dwelling foraminifer, and used as a proxy for tracking the seasonal and permanent thermocline in the subtropical ocean (Lohmann and Schweitzer, 1990; McKenna and Prell, 2004; Cléroux et al., 2007; Cléroux et al., 2009; Feldjeimer et al., 2015). Modern plankton tow and core-top studies have suggested geochemical gradients between $G$ truncatulinoides and intermediate to shallow dwelling planktic foraminifera can be used to reconstruct upper water column structure in the past (Steph et al., 2009; Wilke et al., 2009; Cléroux et al., 2008; Cléroux et al., 2013; Rebotim et al., 2016). Oxygen isotopes in G truncatulinoides have been used to infer lateral density gradients at in termediate depths using core top transects across the Florida Straits (LeGrande et al., 2004), and to reconstruct upper ocean flow in downcore records in the Gulf Stream region (LeGrande and LynchStieglitz, 2007). In the South China Sea and Okinawa Trough, G. truncatulinoides abundance has been used to track the upper ocean thermal structure over the past $1.5 \mathrm{Ma}$ (Jian et al., 2000). The measured $\delta^{18} \mathrm{O}$ of down core records from the encrusted form of this species have also

\footnotetext{
"Corresponding author at: U.S. Geological Survey, 600 4th Street South, St. Petersburg, FL 33701, USA.

E-mail address: creynolds@usgs.gov (C.E. Reynolds).

https://doi.org/10.1016/j.marmicro.2018.05.006

Received 30 January 2018; Received in revised form 18 May 2018; Accepted 22 May 2018 0377-8398/ Published by Elsevier B.V.
}

Please cite this article as: Reynolds, C.E., Marine Micropaleontology (2018), https://doi.org/10.1016/j.marmicro.2018.05.006 


\section{ARTICLE IN PRESS}

been used to reconstruct the separation latitude of the Gulf Stream (Matsumoto and Lynch-Stieglitz, 2003).

Globorotalia truncatulinoides, a keeled non-spinose species of planktic foraminifera, has a cosmopolitan distribution in subtropical to tropical marine environments. As individuals sink into colder, denser waters they add a thick calcite crust which doubles the total mass of the test, but not the overall size of the test (Lohmann and Schweitzer, 1990). Constraint on the depth of encrustation would improve both the ability to track changes in the deep subsurface ocean and reconstruct water column structure over glacial-interglacial cycles (Feldmeijer et al., 2015), and provide estimations of the heat transport during these cycles in the global oceans (Mulitza et al., 1997).

Spatial distribution differences have been reported for the right coiling (dextral) and left coiling (sinistral) forms of $G$. truncatulinoides. The dextral form has been linked to warmer temperatures and a shallower thermocline (Feldmeijer et al., 2015) as well as nutrient-rich waters associated with gyres and coastal margins (Renaud and Schmidt, 2003; Ujiié et al., 2010; Billups et al., 2016). Kennett (1968) cited morphometric differences in G. truncatulinoides, with highly conical forms versus a more compressed form linked to average surface water temperature. A lower ratio of width to height is associated with warmer tropical waters whereas the more compressed form, with a higher ratio of width to height, suggests colder subtropical temperatures. This is corroborated by isotopic studies showing that the highly conical morphotype is significantly more depleted in $\delta^{18} \mathrm{O}$ than the compressed morphotype (Healy-Williams et al., 1985; Williams et al., 1988).

Previously published observations of $G$. truncatulinoides from stratified plankton tows indicate a variable depth habitat in the tropical to sub-tropical North Atlantic Ocean. Fairbanks et al. (1980) found living G. truncatulinoides throughout the upper $200 \mathrm{~m}$ of the water column, with peak population between 125 and $175 \mathrm{~m}$ during a November
MOCNESS tow in the western subtropical North Atlantic Ocean. They note that the oxygen isotopic composition of specimens from the upper $200 \mathrm{~m}$ of the water column indicate a bi-modal distribution, with one population in isotopic equilibrium with the surface mixed layer, and the other from 125 to $200 \mathrm{~m}$. A spring MOCNESS plankton tow from the upper $100 \mathrm{~m}$ in the eastern equatorial Atlantic Ocean found living $G$. truncatulinoides only in $80-100 \mathrm{~m}$ water depth (Ravelo and Fairbanks, 1992), and a spring tow in the Caribbean found maximum abundance from 100 to $200 \mathrm{~m}$ (Schmuker and Schiebel, 2002). Rebotim et al. (2016) synthesized results from 43 plankton tows from the eastern North Atlantic spanning the annual cycle, and found that the average habitat depth of $G$. truncatulinoides shifts from $-30 \mathrm{~m}$ in winter to $250 \mathrm{~m}$ in the spring. Plankton tow data from the eastern subtropical South Atlantic Ocean indicate the presence of living $G$. truncatulinoides throughout the upper $400 \mathrm{~m}$, with maximum shell concentrations below $300 \mathrm{~m}$ water depth (Loncaric et al., 2006).

Depth habitat of $G$. truncatulinoides has also been estimated by comparing foraminiferal $\delta^{18} \mathrm{O}$ with the predicted $\delta^{18} \mathrm{O}$ of calcite in equilibrium with seawater. For example, using this approach with sediment trap material in the Sargasso Sea, Anand et al. (2003) reported a depth habitat for $G$. truncatulinoides of 200-500 m. Cléroux et al. (2013) estimated depth habitat between 300 and $535 \mathrm{~m}$ using core-top measurements spanning the mid-Atlantic. In a network of core-top samples spanning the subtropical to sub-polar North Atlantic, Cléroux et al. (2007) determined that $G$. truncatulinoides inhabits the base of the seasonal thermocline, with a preference for water temperatures cooler than $16^{\circ} \mathrm{C}$. These results, which suggest that $G$. truncatulinoides is in isotopic equilibrium within or below the seasonal thermocline $(\sim 100-400 \mathrm{~m})$, are consistent with studies spanning the Atlantic Basin (Mortyn and Charles, 2003; Loncaric et al., 2006; Regenberg et al., 2009; Steph et al., 2009; summarized in Table 1).

Table 1

Summary of Globorotalia tnmcatulinoides depth habitat observations or determinations.

\begin{tabular}{|c|c|c|c|c|}
\hline Study & Location & Collection Type & Depth $(\mathrm{m})$ & $8^{18} \mathrm{O}$ equation used \\
\hline Anand et al. (2003) & Sargasso Sea & Sediment Trap & $200-500$ & $\begin{array}{l}\text { O'Neil et al. (1969) and } \\
\text { Shackieton (1974) }\end{array}$ \\
\hline Cléroux et al. (2007) & $\begin{array}{l}\text { subtropical to northern North } \\
\text { Atlantic }\end{array}$ & core tops & $200-400$ & Shackleton (1974) \\
\hline Cléroux et al. (2009) & Western Atlantic Ocean & cores & $200-300$ & \\
\hline Cléroux et al. (2013) & mid-Atlantic & core top measurements & $\begin{array}{l}420 \pm 115 \\
300\end{array}$ & $\begin{array}{l}\text { Kim and oNeil (1997) } \\
\text { Shackleton (1974) }\end{array}$ \\
\hline Deuser and Ross (1989) & Sargasso Sea & Sediment Trap & 200 & \\
\hline Fairbanks et al. (1980) & subtropical North Atlantic & MOCNESS plankton tow & $125-175$ & \\
\hline Loncaric et al. (2006) & $\begin{array}{l}\text { eastern subtropical South Atlantic } \\
\text { Ocean }\end{array}$ & plankton tow & 340 & Kim and ONeil, 1997 \\
\hline McKenna and Prell (2004) & western Indian Ocean & core tops & 200 & O'Neil et al. (1969) \\
\hline Mortyn and Charles (2003) & $\begin{array}{l}\text { Atlantic sector of the Southern } \\
\text { Ocean }\end{array}$ & MOCNESS plankton tow & $100-500$ & O'Neil et al. (1969) \\
\hline Mulitza et al. (1997) & Atlantic Ocean & sediment surfaces & 250 & \\
\hline Ravelo and Fairbanks (1992) & eastern equatorial Atlantic Ocean & MOCNESS plankton tow & $80-100$ & \\
\hline Rebotim et al. (2016) & eastern North Atlantic & $\begin{array}{l}\text { core tops } \\
\text { plankton tows }\end{array}$ & $\begin{array}{l}125-200 \\
30 \text { (winter) to } 250 \text { (spring) }\end{array}$ & \\
\hline \multirow[t]{2}{*}{ Regenberg et al. (2009) } & Caribbean, West and East Atlantic & sediment surface samples & $377 \pm 99$ & Bemis et al. (1998) \\
\hline & & & $\begin{array}{l}380 \pm 105 \\
478 \pm 109\end{array}$ & $\begin{array}{l}\text { Kim and ONeil (1997) } \\
\text { Mulitza et al. (2004) }\end{array}$ \\
\hline This study & northern Gulf of Mexico & Sediment Trap & $\begin{array}{l}308 \pm 106 \\
66 \pm 9(\mathrm{NC}) \\
379 \pm 76(\mathrm{C})\end{array}$ & $\begin{array}{l}\text { Shackieton (1974) } \\
\text { see Table } 2\end{array}$ \\
\hline \multirow[t]{2}{*}{ Salmon et al. (2016) } & Sargasso Sea & Sediment Trap & $44(\mathrm{NC})$ & $\begin{array}{l}\text { O'Neil et al. (1969) and } \\
\text { Shackleton (1974) }\end{array}$ \\
\hline & & & $300-400(\mathrm{C})$ & \\
\hline $\begin{array}{l}\text { Schmuker and schlebel } \\
\text { (2002) }\end{array}$ & Caribbear & MOCNESS plankton tow & $100-200$ & \\
\hline Steph et al. $(2009)$ & Caribbean, West and East Atlantic & core tops & $\begin{array}{l}208 \pm 50 \text { to } 424 \pm 80 \\
490 \pm 91\end{array}$ & $\begin{array}{l}\text { Shackleton (1974) } \\
\text { Kim and ONell (1997) }\end{array}$ \\
\hline & & & $179 \pm 35$ to $376 \pm 76$ & Shackleton (1974) \\
\hline Spear et al. (2011) & northern Gulf of Mexico & Sediment Trap & 120 & Bemis et al. (1998) \\
\hline Wilke et al. (2009) & Canary Islands & $\begin{array}{l}\text { Plankton tows, Sediment Trap and Core } \\
\text { tops }\end{array}$ & 350 & Kim and ONeil, 1997 \\
\hline
\end{tabular}




\section{ARTICLE IN PRESS}

Globorotalia truncatulinoides is assumed to be a deep, subsurface dweller because studies inferring a depth habitat from shell geochemistry do so without discriminating between encrusted and non-encrusted $G$. truncatulinoides. Spear et al. (2011) suggested that $G$. truncatulinoides encrusted (C) and non-encrusted (NC) forms occupy distinct depth habitats in the nGoM and argued that NC G. truncatulinoides in the nGoM calcifies no deeper than $120 \mathrm{~m}$ (the base of the winter mixed layer). Salmon et al. (2016) also separated the two forms and found a similar shallow $(\sim 44 \mathrm{~m})$ depth habitat for NC in winter in the Sargasso Sea. Two additional studies used electron microprobe analysis to compare the $\mathrm{Mg} / \mathrm{Ca}$ of the lamellar (early ontogenic) calcite versus the secondary crust; both concluded that the lamellar calcite formed in the mixed layer, above the thermocline (Duckworth, 1977; McKenna and Prell, 2004).

We demonstrate in this study that due to the complex life history of G. truncatulinoides, the $\mathrm{C}$ and $\mathrm{NC}$ forms have geochemical signals that reflect distinctly different calcification depths, with the latter representing winter surface mixed layer conditions, and the former representing deep subsurface conditions. By not discriminating between the two forms in down core studies, geochemical changes recorded by G. truncatulinoides may reflect changes in the relative proportion of the surface and deep-dwelling forms, rather than paleoceanographic changes in upper ocean hydrography.

\section{Proxy approach}

The relatively low abundance of NC G. truncatulinoides specimens in both sediment trap and down core samples in the nGoM precludes solution-based $\mathrm{Mg} / \mathrm{Ca}$ analysis. Therefore, we test the efficacy of using laser ablation inductively coupled plasma mass spectrometry (LA-ICPMS) on individual foraminiferal chambers to approximate the mean $\mathrm{Mg} / \mathrm{Ca}$ of the whole test. LA-ICP-MS has become a powerful tool to investigate the heterogeneity in trace elements within foraminiferal tests (e.g. Eggins et al., 2003). This high precision elemental analysis allows many discrete measurements to be taken in a continuous profile through a chamber wall, providing insights into the calcification process that are obscured by solution-based bulk shell analysis. LA-ICP-MS has been used to analyze non-spinose planktic foraminiferal species such as Neogloboquadrina dutertrei, Globorotalia scitula, and Pulleniatina obliquiloculata to investigate differences between the trace metal composition of lamellar calcite and secondary crust (e.g., Jonkers et al. 2012; Steinhardt et al., 2015). Other studies have used LA-ICP-MS to analyze sediment trap samples to explore relationships between the foraminiferal geochemistry and water column hydrography (Gibson et al., 2016), and to identify and avoid potential contamination, diagenesis, and dissolution (Vetter et al., 2013). Recently, Vetter et al. (2017) highlighted the potential for paired $\delta^{18} \mathrm{O}$ and LA-ICP-MS (Mg/ $\mathrm{Ca}$ and $\mathrm{Ba} / \mathrm{Ca}$ ) analysis on individual foraminifera shells in a study that reconstructed deglacial Mississippi River meltwater geochemistry.

Here we present paired isotopic $\left(\delta^{13} \mathrm{C}\right.$ and $\left.\delta^{18} \mathrm{O}\right)$ and $\mathrm{Mg} / \mathrm{Ca}$ data obtained from individual Globorotalia truncatulinoides specimens from a weekly-resolved sediment trap time series in the nGoM. Using this approach, we are able to take a detailed investigation of the geochemical differences between encrusted and non-encrusted forms. We use this information to (1) validate the $\mathrm{Mg} / \mathrm{Ca}$-calcification temperature relationship for $G$. truncatulinoides, (2) demonstrate that the non-encrusted form calcifies in the surface mixed layer, whereas the crust forms well below the seasonal thermocline, and (3) demonstrate that LA-ICP-MS analyses of single foraminifera can be used to yield comparable elemental ratios to that obtained from solution-based analyses.

\section{Oceanographic setting}

The GoM is a semi-enclosed basin surrounded by the Gulf Coast of the United States, Mexico, and Cuba (Fig. 1). Climatic sea-surface temperatures (SST) at the sediment trap site $\left(27.5^{\circ} \mathrm{N}\right.$ and $90.3^{\circ} \mathrm{W}$ ) range from $20.7 \pm 0.6$ degrees Celsius $\left({ }^{\circ} \mathrm{C}\right)$ in winter to $30.0 \pm 0.3^{\circ} \mathrm{C}$ in summer (HadISST $1 \times 1$ gridded data 1870-2013). The winter mean temperature (JFM) from the HadISST gridded data set for the sampling period in this study (2010-2014) is $20.6 \pm 1.1^{\circ} \mathrm{C}$ (Rayner et al., 2003). Sea-surface salinity (SSS) ranges from a climatic monthly winter maximum of 36.5 practical salinity units (psu) to a summer minimum of 34.5 psu (World Ocean Atlas, 2009, Antonov et al., 2010), although sporadic low salinity events are observed at the sediment trap site that result from interaction with Mississippi River discharge and/or entrainment of lower salinity coastal waters in mesoscale eddies (Walker et al., 2011 and Huang et al., 2013).

The GoM is connected to the Caribbean and tropical North Atlantic by the Loop Current. The Loop Current is a surface current that enters the GoM from the Caribbean Sea between Cuba and the Yucatan Peninsula and typically loops to the east and south before exiting through the Straits of Florida (Vukovich, 1988). Portions of the Loop Current often break off and form anticyclonic or warm-core eddies that propagate northward and westward (Poore et al., 2013), impacting the sediment trap site. The warm-core eddies are the fundamental mechanism for incursion of warm Caribbean waters over our site, and satellite altimetry has been used to discern a periodicity of approximately 6-10 months for these eddy events (Dukhovskoy et al., 2015). Although SST variability at the sediment trap site is dominated by the seasonal cycle, mesoscale eddies associated with the loop current eddy shedding process may be responsible for short-term (sub-annual) anomalies.

\section{Materials and methods}

\subsection{Foraminifera collection and cleaning}

A McLane PARFLUX Mark 78 automated sediment trap was deployed in January 2008 in $1150 \mathrm{~m}$ of water in the nGoM (Figs. 1, 27.5 $\mathrm{N}$ and $90.3^{\circ} \mathrm{W}$ ). The trap was positioned in the water column at a depth of $700 \mathrm{~m}$ on the mooring cable to enable the collection of deeper dwelling species of planktic foraminifera. The trap was equipped with

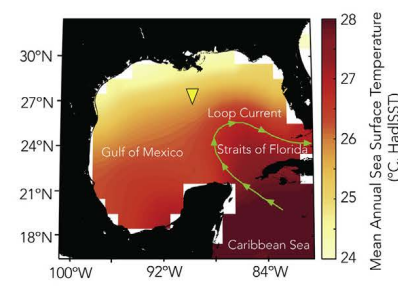

$$
\text { B. }
$$

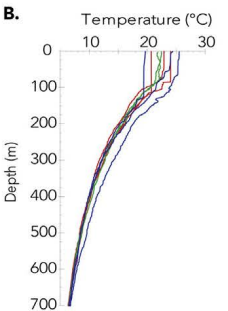

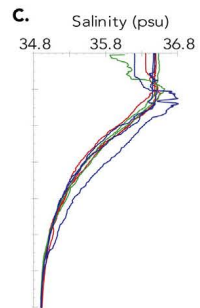

Fig. 1. (A) Map of climatic mean annual SST (HadlssT, Rayner et al., 2003). Location of the sediment trap mooring in the Gulf of Mexico at approximately $27.5^{\circ} \mathrm{N}$ and $90.3^{\circ} \mathrm{W}$ (yellow triangle). The green line shows the loop current. (B) Temperature $\left({ }^{\circ} \mathrm{C}\right.$ ), and $(\mathrm{C})$ salinity (psu) CTD profiles from the upper $700 \mathrm{~m}$ during 2008-2017 cruises at the sediment trap site in January (red), February (green), and March (blue). (For interpretation of the references to colour in this figure legend, the reader is referred to the web version of this article.) 


\section{ARTICLE IN PRESS}

C.E. Reynolds et al.

21 collection cups mounted on a rotating plate, programmed to rotate every 7 to 14 days. Details of the sediment trap sampling can be found in Reynolds and Richey (2016).

Once collected, one quarter split of each cup was wet sieved over a $150 \mu \mathrm{m}$ sieve and wet picked for all foraminifera and identified to species. One hundred and thirty-four $G$. truncatulinoides specimens were picked based on availability from January 2010 through March 2014 (40 encrusted specimens, collected January to April, and 94 non-encrusted specimens, collected January to December). The most common size fraction for NC individuals is $300-425 \mu \mathrm{m}$ in JFM (Fig. S1, Supplementary materials). Three of the 134 individuals were sinistral (left-coiling) whereas the remaining 131 were dextral (right-coiling) the most common morphotype in the GoM (Billups et al., 2016). Whole shell G. truncatulinoides were cleaned according to modified procedures
Marine Micropaleontology $x x x(x x x x) x x x-x x x$

for laser ablation (Vetter et al., 2013; Fehrenbacher et al., 2015). Samples were cleaned by ultrasonicating in methanol followed by triple-rinsing in Milli- $\mathrm{Q}$ water $(18.2 \mathrm{M} \Omega \cdot \mathrm{cm})$. Shells were then oxidatively cleaned at $60^{\circ} \mathrm{C}$ for $30 \mathrm{~min}$ in a buffered hydrogen peroxide solution ( $1: 1 \mathrm{mix}$ of $30 \%$ hydrogen peroxide and $0.1 \mathrm{~N}$ sodium hydroxide) to remove remnant organic matter. Finally, the shells were again triple rinsed in Milli-Q water. Once dry, each individual's length was measured across the diameter of the umbilical side, from the tip of the final chamber to the opposite side (ranging 295-738 $\mu \mathrm{m}$ ) and weighed (4.5-94.5 $\mu \mathrm{g}$ ) on a microbalance. $1 \sigma$ error on length measurements $( \pm 16 \mu \mathrm{m})$ and weight measurements $( \pm 0.6 \mu \mathrm{g})$ are based on repeated measurements by separate analysts. Because there is a gradient between the completely encrusted and non-encrusted forms of $G$. truncatulinoides (Fig. 2), visual discrimination between the two forms can be somewhat
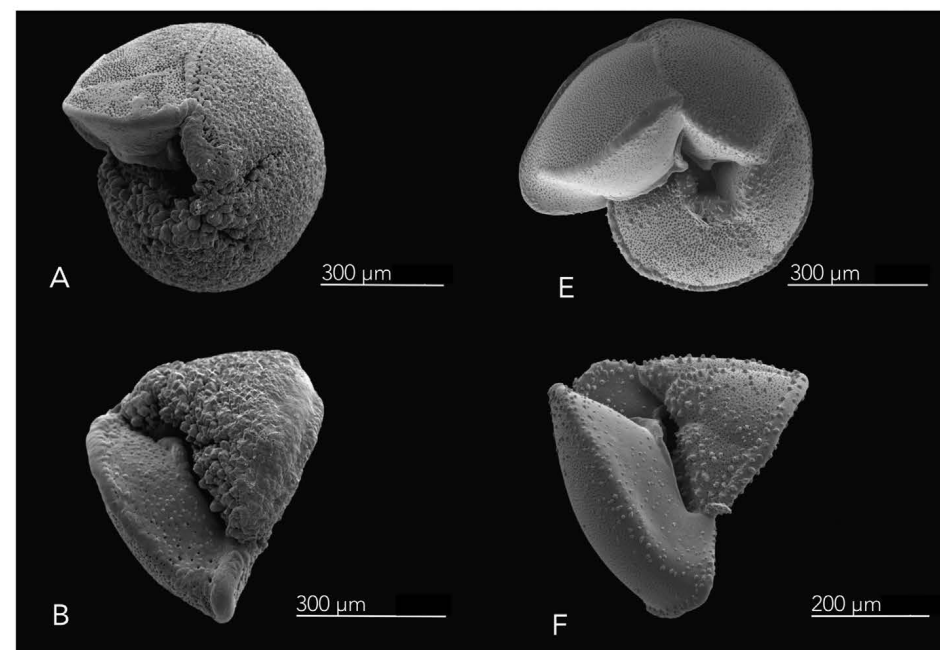

C

$300 \mu \mathrm{m}$
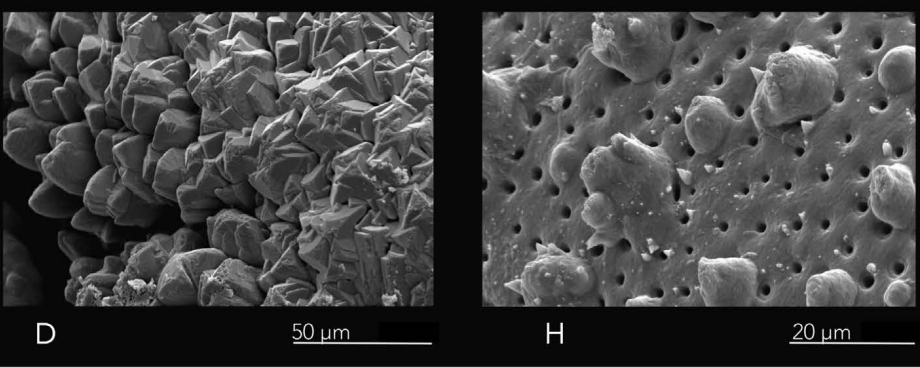

Fig. 2. Scanning electron microscope (SEM) images of encrusted Globorotalia truncatulinoides (A-D) and the non-encrusted form (E-H). Panels D and H show differences in encrustation near the aperture. 


\section{ARTICLE IN PRESS}

C.E. Reynolds et aL.

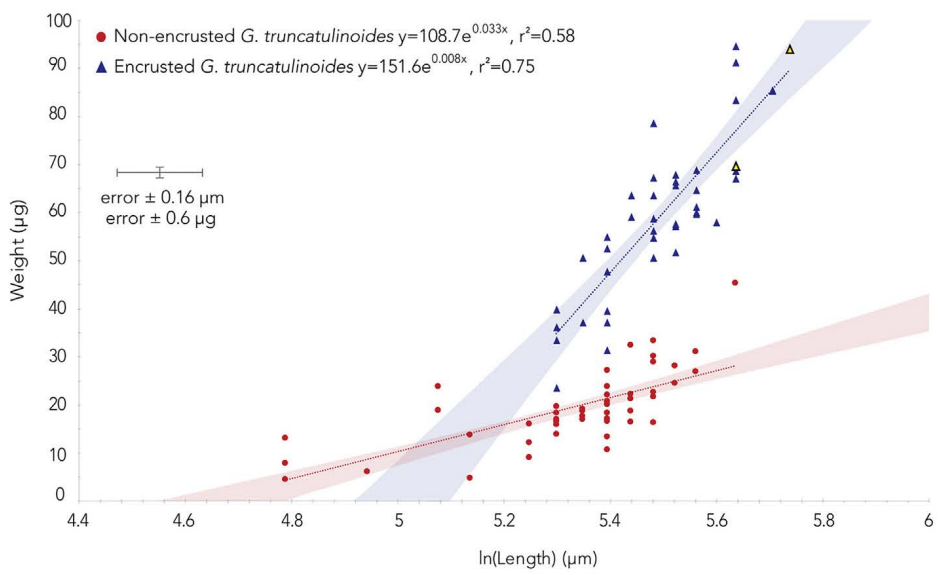

Marine Micropaleontology $x x x(x x x x) x x x-x x x$

Fig. 3. Length-weight relationship between non-encrusted (red circles) and encrusted (blue tringles) $G$. truncatulinoides. The $95 \%$ confidence interval for each exponential trend line is shaded red for NC and blue for $\mathrm{C}$. The two yellow individuals outlined in black triangles are $G$. truncatulinoides we visually identified as non-encrusted specimens under the microscope but all other evidence, including their biometrics and geochemistry suggest they were encrusted. $1 \sigma$ error on length measurements $( \pm 0.16 \mu \mathrm{m})$ and weight measurements $( \pm 0.6 \mu \mathrm{g})$ are based on repeated measurements by separate analysts. (For interpretation of the references to colour in this figure legend, the reader is referred to the web version of this article.) subjective under the binocular microscope. Pustules, which may appear like early encrustation, are present on every individual, even on juvenile forms $(150 \mu \mathrm{m})$. Hemleben (1975) pointed out that these features are present on other Globorotaliids (e.g., G. menardii and G. inflata), and are larger/more concentrated around the keel and the aperture of fossil specimens. He postulates that they serve as attachment points for the pseudopodia, which would imply that they are independent of a crust that forms at a later ontogenetic stage. Using scanning electron microscope (SEM) imaging is more definitive. The length-weight relationship (Fig. 3) shows that the morphometric differences can be used to distinguish between $\mathrm{C}$ and NC G. truncatulinoides when visual distinction is ambiguous. The width-to-height ratios were $1.26 \pm 0.14$ and $1.29 \pm 0.09$ for NC and C, respectively. These ratios put the GoM $G$. truncatulinoides on the most highly conical end of the spectrum, identified by Kennett (1968) as tropical to northern sub-tropical morphotypes, and suggest that both the $\mathrm{C}$ and $\mathrm{NC}$ are the same morphotype in the nGoM, varying only in degree of encrustation.

\subsection{Foraminifera laser ablation techniques}

Laser ablation inductively coupled plasma mass spectrometry (LAICP-MS) was conducted at The University of California, Davis Stable Isotope Laboratory, using Photon Machines $193 \mathrm{~nm}$ ArF UV excimer laser with an ANU HelEx dual-volume laser ablation cell coupled to an Agilent $7700 \times$ quadrupole-ICP-MS (Table S1, supplementary

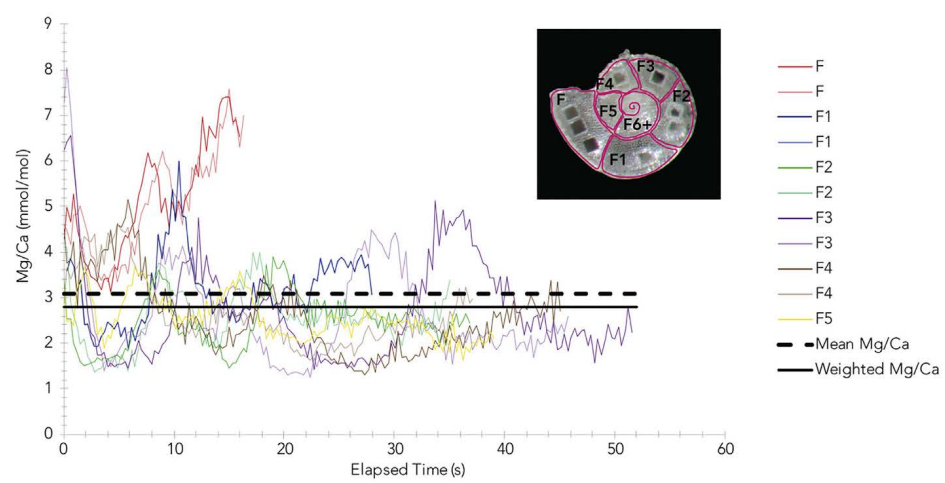

materials). G. truncatulinoides specimens were placed on double sided carbon tape spiral side up to ensure a horizontal sampling surface for each chamber (Fig. 4, inset). Laser spot size of $44 \times 44 \mu \mathrm{m}$ in diameter was used with a repetition rate of $6 \mathrm{~Hz}$ (non-encrusted forms) and $8 \mathrm{~Hz}$ (encrusted forms). Due to the thickness of the calcite in the encrusted form, a higher repetition rate was needed to ablate through the shell. For the smallest foraminifera, the spot size was decreased to $30 \times 30$ $\mu \mathrm{m}$ to ensure ablation within a single chamber. Depth profiles were obtained on each chamber (F through up to F7). If chambers were large enough, up to 3 repeat spot analyses were obtained to assess reproducibility. Masses measured were ${ }^{24} \mathrm{Mg},{ }^{25} \mathrm{Mg},{ }^{27} \mathrm{Al},{ }^{44} \mathrm{Ca},{ }^{55} \mathrm{Mn},{ }^{88} \mathrm{Sr},{ }^{89} \mathrm{Y}$, and ${ }^{138} \mathrm{Ba}$. SRM NIST 610,612 , and 614 glass standards were run before and after each batch of samples as an external standard. An Orbulina universa shell, which is demonstrated to have highly reproducible trace element profiles throughout, was analyzed before and after each run as an internal working standard $(7.0 \pm 0.7 \mathrm{mmol} / \mathrm{mol} \mathrm{Mg} / \mathrm{Ca}, 2 \sigma$, Fehrenbacher et al., 2015). Outliers in the $\mathrm{Mg} / \mathrm{Ca}$ profiles that were greater than \pm 6 standard deviations from a 3-point rolling mean were removed from raw LA-ICP-MS signals, then data were reduced using Iolite Software (Paton et al., 2011).

\subsection{Determining a whole shell $M g / C a$ value from LA-ICP-MS analyses}

Using an inductively coupled plasma optical emission specrometer (ICP-OES), solution-based $\mathrm{Mg} / \mathrm{Ca}$ analysis requires $\sim 200 \mu \mathrm{g}$ of calcite
Fig. 4. Laser ablated $\mathrm{Mg} / \mathrm{Ca}$ profiles for all spots (11) and all chambers (F-F5) on a single non-encrusted $G$. truncatulinoides (sample ID: 6-17-NC1). The mean $\mathrm{Mg} / \mathrm{Ca}$ of all data (black dashed line) and the mean weighted $\mathrm{Mg} / \mathrm{Ca}$ of all data (black line) is shown. Inset: photograph of a laser ablated non-encrusted $G$. truncatulinoides spiral side (flat side). Each chamber is outlined. Chamber $\mathrm{F}$ is the final chamber and numbered chambers increase inward. Spot size is $44 \times 44$ $\mu \mathrm{m}$. Note the photograph and the data are not from the same individual (shown only to demonstrate chambers and ablation spots). (For interpretation of the references to colour in this figure legend, the reader is referred to the web version of this article.) 


\section{ARTICLE IN PRESS}

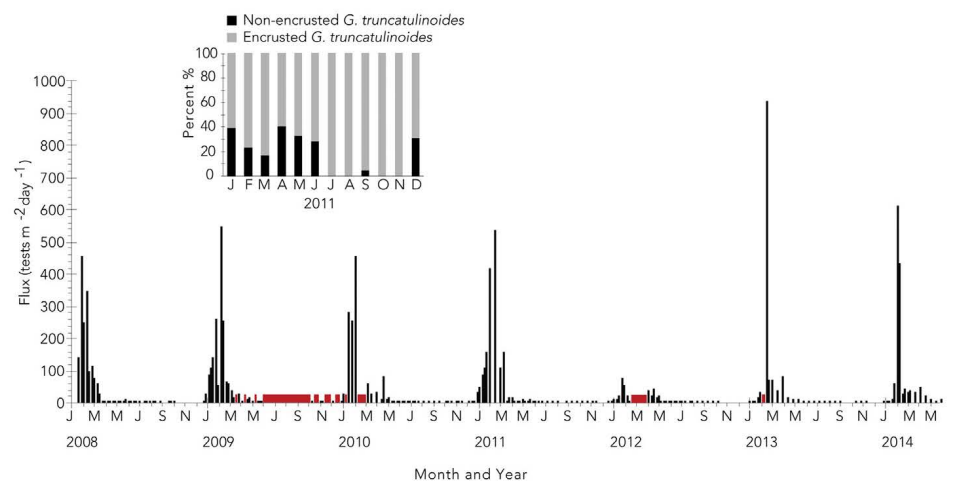

Fig. 5. G. truncatulinoides flux (tests $\mathrm{m}^{-2} \mathrm{day}^{-1}$ ) from all sediment trap samples 2008-2014. Red bars indicate gaps in sampling and missing sample cups from the trap. Inset panel is the relative percentage of non-encrusted verses encrusted $G$. truncatulinoides for each month in 2011. (For interpretation of the references to colour in this figure legend, the reader is referred to the web version of this article.)

(or 5-15 crushed and homogenized G. truncatulinoides specimens). Recent studies have successfully measured $\mathrm{Mg} / \mathrm{Ca}$ on single foraminifera (10 $\mu \mathrm{g}$ calcite) using solution-based ICP-MS (Marchitto, 2006; Rongstad et al., 2017). Here, we elect to use LA-ICP-MS analyses of individual foraminifera to approximate solution-based whole shell $\mathrm{Mg}$ / Ca measurements for an individual foraminifer. This allows for paired $\mathrm{Mg} / \mathrm{Ca}$ and $\delta^{18} \mathrm{O}$ analysis on the same individual foraminifer. For each chamber, 1 to 3 spots were ablated. The 5 chambers in the final whorl (F4, F3, F2, F1 and F) represent the adult ontogenetic stage in $G$. truncatulinoides (Caromel et al., 2016), and every foraminifer had at least the final three chambers (F, F1, and F2) analyzed. For a subset of foraminifera, we ablated back to F7. We determined that the weighted mean of the final three chambers can be used to approximate the mean $\mathrm{Mg} / \mathrm{Ca}$ of chambers F-F7 within $0.2 \mathrm{mmol} / \mathrm{mol}$. We use $0.2 \mathrm{mmol} / \mathrm{mol}$ as a benchmark for the acceptable level of uncertainty, as it is the average intra-sample standard deviation from our solution-based $\mathrm{Mg}$ / $\mathrm{Ca}$ analyses (Fig. S2, Supplementary materials).

There is considerable $\mathrm{Mg} / \mathrm{Ca}$ heterogeneity both within a single chamber wall and between chambers in an individual foraminifer. For example, $\mathrm{Mg} / \mathrm{Ca}$ varies between 1.4 and $8.1 \mathrm{mmol} / \mathrm{mol}$ for all profiles measured on an individual $G$. truncatulinoides collected in January of 2010 (Fig. 4). One option to approximate the whole shell $\mathrm{Mg} / \mathrm{Ca}$ is to simply take the mean of all $\mathrm{Mg} / \mathrm{Ca}$ determinations, which is $3.09 \mathrm{mmol} /$ mol for this shell. Instead, we account for the relative contribution of each chamber to the overall test composition by weighting the chambers according to ablation time, which is proportional to calcite thickness. For this individual the weighted mean $(2.80 \mathrm{mmol} / \mathrm{mol})$ is lower than the unweighted mean $(3.09 \mathrm{mmol} / \mathrm{mol})$, which is equivalent to a $1.1{ }^{\circ} \mathrm{C}$ difference in the resulting temperature estimate. Another example of weighting $\mathrm{Mg} / \mathrm{Ca}$ for greater accuracy for all February NC individuals is shown in Fig. S3 (Supplementary materials).

In order to address uncertainty on the weighted $\mathrm{Mg} / \mathrm{Ca}$, we generated a combined error term (Root Mean Square, RMS) based on 1) analytical error $(S D 1=0.35 \mathrm{mmol} / \mathrm{mol}$, based on $1 \sigma$ of replicate measurements of $O$. universa internal working standard), 2) intrasample variability $(\mathrm{SD} 2=0.81 \mathrm{mmol} / \mathrm{mol}$ based on nine individual $\mathrm{NC}$ $G$. truncatulinoides specimens from the same sediment trap samples), and 3) uncertainty in analytical technique (SD3 $=0.30$ or $0.34 \mathrm{mmol}$ / $\mathrm{mol} 1 \sigma$ between solution-based and laser ablation-based $\mathrm{Mg} / \mathrm{Ca}$ for $\mathrm{NC}$ and $\mathrm{C}$, respectively) (Eq. (1)). Using this estimate of total $\mathrm{Mg} / \mathrm{Ca}$ un certainty the RMS error on weighted $\mathrm{Mg} / \mathrm{Ca}$ is $0.93 \mathrm{mmol} / \mathrm{mol}$ and $0.95 \mathrm{mmol} / \mathrm{mol}$, for NC and C respectively.

$\mathrm{RMS}=\sqrt{S D(1)^{2}+S D(2)^{2}+S D(3)^{2}}$

\subsection{Isotopic measurements}

Stable isotopes, $\delta^{18} \mathrm{O}$ and $\delta^{13} \mathrm{C}$ of calcite $\left(\delta^{18} \mathrm{O}_{c}\right.$ and $\left.\delta^{13} \mathrm{C}_{c}\right)$, were analyzed on individual foraminifera, ranging in weight from 5 to $95 \mu \mathrm{g}$, after LA-ICP-MS analyses were completed. Foraminifera were roasted under vacuum at $75^{\circ} \mathrm{C}$ for $1 \mathrm{~h}$ to eliminate remaining volatile organics from carbon tape. Isotopic analyses were performed at The University of California, Davis Stable Isotope Laboratory, on a Fisons Optima isotope ratio mass spectrometer (IRMS). The IRMS is calibrated using the NBS-19 standard and has a long-term one sigma precision for carbonates $\pm 0.04 \%$ and $\pm 0.05 \%$ for $\delta^{13} \mathrm{C}_{\mathrm{c}}$ and $\delta^{18} \mathrm{O}_{\mathrm{c}}$, respectively. This is based on 110 standards analyzed during the summer 2016 .

\section{Results and discussion}

\subsection{Globorotalia truncatulinoides flux in the nGoM}

The six-year (2008-2014) sediment trap time series of $G$. truncatulinoides flux in the nGoM displays a clear seasonality, with $92 \%$ of annual flux (tests $\mathrm{m}^{-2} \mathrm{day}^{-1}$ ) occurring in the winter months of January, February, and March (Fig. 5). Weekly JFM flux, for both encrusted and non-encrusted forms, ranges from 3 to 932 tests $\mathrm{m}^{-2} \mathrm{day}^{-1}$, with a mean flux of 130 tests $\mathrm{m}^{-2}$ day $^{-1}$ whereas the remaining months (April-December) have weekly fluxes ranging 0 to 85 tests $\mathrm{m}^{-2} \mathrm{day}^{-1}$, with a mean flux of 4 tests $\mathrm{m}^{-2} \mathrm{day}^{-1}$. Total planktic foraminiferal assemblage data for the nGoM sediment trap can be found in Poore et al. (2013) and Reynolds and Richey (2016).

The encrusted and non-encrusted forms of $G$. truncatulinoides have not been differentiated for the majority of the 2008-2014 sediment trap faunal analysis. However, for 2011 we counted the two forms separately, and plot the relative percentage of $\mathrm{C}$ and $\mathrm{NC}$ for each month. The data show the encrusted form totaling at least $61 \%$ of the G. truncatulinoides population for each month and $100 \%$ of the population in the low-flux months of July, August, October, and November (Fig. 5). The absence of the non-encrusted form in the non-winter months supports the hypothesized annual reproduction of G. truncatulinoides, however, the mechanism is not clear.

The literature suggest that encrusted individuals return to the surface from below the thermocline to release gametes (Hemleben et al., 1985; Deuser and Ross, 1989; Schiebal and Hemleben, 2005). This is unlikely, given the absence of significant upwelling and the fact that the abundance of encrusted individuals approaches zero in the non-winter months as well. With the exception of $G$. truncatulinoides, ten of the most common foraminiferal species in the nGoM exhibit lunar periodicity in their shell flux, suggesting synchronization between reproduction and lunar phase (Jonkers et al., 2015). This further suggests that the annual reproductive strategy of $G$. truncatulinoides is unique in 


\section{ARTICLE IN PRESS}

C.E. Reynolds et aL.

Non-encrusted G. truncatulinoides

A.
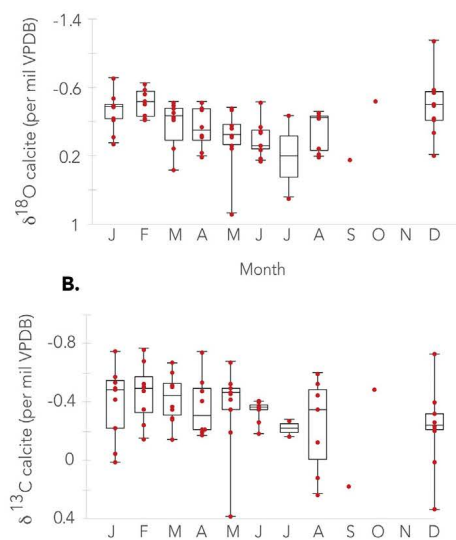

Month
Encrusted G. truncatulinoides

c.

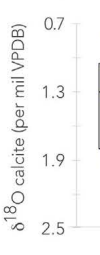

D.

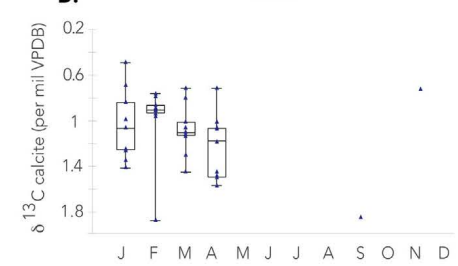

Marine Micropaleontology $x x x(x x x x) x x x-x x x$

Fig. 6. Monthly box and whisker plots of all nonencrusted ( $A$ and $B$ ) and encrusted ( $C$ and $D$ ) G.truncatulinoides stable isotopes $\delta^{18} \mathrm{O}_{\mathrm{c}}(\mathrm{A}$ and $\mathrm{C})$ and $\delta^{13} \mathrm{C}_{\mathrm{c}}$ (B and D), note the change in scale for all plots. The median, IQR, and range are represented as well as the actual data points for non-encrusted $G$. truncatulinoides (red circles) and encrusted (blue triangles). (For interpretation of the references to colour in this figure legend, the reader is referred to the web version of this article.)

this environment. It is possible that $G$. truncatulinoides is being transported from the Caribbean via the Loop Current. However, Loop Current incursion into the nGoM peaks in late summer (Lindo-Atichati et al., 2013), which is inconsistent with the winter flux spike. This is also an unlikely explanation given that other parts of the North Atlantic experience similar winter weighted seasonal flux (Tolderlund and $\mathrm{Be}$, 1971). Another possibility is that the residual population during the non-winter months is sufficient to support a flux increase of 2 orders of magnitude in response to an environmental stimulus, like temperature.

\subsection{Globorotalia truncatulinoides encrustation}

All G. truncatulinoides, both $\mathrm{C}$ and $\mathrm{NC}$, start their life cycle in the upper water column as non-encrusted individuals. Lohmann (1995) states secondary calcite is added only at depth to the fully-formed adult whereas the lamellar calcification occurs near the surface during growth and chamber formation. If we assume that the lamellar calcite is formed within the surface mixed layer, and that encrustation occurs after the final chamber is formed, we can use the length-weight relationships determined for $C$ and NC $G$. truncatulinoides to estimate the relative contribution of mixed layer calcite to an encrusted specimen. Over the typical size range of individuals found in $\mathrm{nGoM}$ sediments $(400-700 \mu \mathrm{m})$, we estimate that $68-71 \%$ of the calcite is coming from the secondary crust, with lamellar calcite secreted in the mixed layer accounting for the other $29-32 \%$. We calculated the difference between predicted $\mathrm{C}$ and NC weight at lengths of 400 and $700 \mu \mathrm{m}$ using the $\mathrm{ln}$ (length) versus weight equations from Fig. 3. For example, based on our length-weight regressions for $\mathrm{C}$ and $\mathrm{NC}$, an encrusted specimen at a length of $400 \mu \mathrm{m}$ weighs $123 \pm 12 \mu \mathrm{g}$ and a non-encrusted specimen of the same length weighs $39 \pm 14 \mu \mathrm{g}$, implying $32 \%$ of an average 400 um encrusted individual is comprised of lamellar calcite. We used a second independent method to calculate the relative percentage of lamellar versus secondary calcite in encrusted individuals; we identified the secondary crust in laser ablation profiles and compared its ablation time to that of the lamellar calcite on the inner part of the shell. The crust can be identified in laser ablation profiles because it is homogenous and much lower in $\mathrm{Mg} / \mathrm{Ca}$ and $\mathrm{Ba} / \mathrm{Ca}$ than the lamellar calcite (Fig. S4, Supplementary materials). The secondary crust accounts for 71 ( \pm 10 ) $\%$ of the total shell, on average, validating our estimate using length/weight relationships. LeGrande et al. (2004) estimated that $44 \%$ of surface calcification is incorporated into the total shell. Sadekov et al.
(2005) concluded that the outer crust accounts for $40 \%$ of the chamber wall thickness. If we assume $29 \%$ of the calcite of an encrusted specimen originates in the winter mixed layer, then $\delta^{18} \mathrm{O}_{\mathrm{C}}$ of encrusted specimens underestimates the depth at which the crust is added.

For this reason, we correct $\delta^{18} \mathrm{O}, \delta^{13} \mathrm{C}$, and $\mathrm{Mg} / \mathrm{Ca}$ measurements on encrusted $G$. truncatulinoides to remove the contribution of lamellar calcite. This allows for more accurate estimates of water column conditions during encrustation. For $\delta^{18} \mathrm{O}$ and $\delta^{13} \mathrm{C}$ we use the mean isotopic values of the entire NC dataset $(-0.16 \pm 0.32 \%$ and $-0.34 \pm$ $0.24 \%$, respectively) as the lamellar calcite end-member values. The percent secondary crust was determined for each individual foraminifer via ablation time, then a simple mixing model between the measured isotopes on encrusted individuals and the assumed contribution from lamellar calcite was used to calculate the isotopic composition of the crust. To correct for the contribution of lamellar calcite to $\mathrm{Mg} / \mathrm{Ca}$ of $\mathrm{C}$ individuals, the homogenous zone (crust) $\mathrm{Mg} / \mathrm{Ca}$ value was determined for each chamber and then a weighted average "crust" $\mathrm{Mg} / \mathrm{Ca}$ was derived for every encrusted individual. For the remainder of the paper the $\delta^{18} \mathrm{O}, \delta^{13} \mathrm{C}$, and $\mathrm{Mg} / \mathrm{Ca}$ values we give for encrusted individuals will be corrected for the contribution of mixed layer calcite.

\subsection{Isotopic composition of $G$. truncatulinoides in the $n G o M$}

Stable carbon and oxygen isotopic analyses were performed on individual foraminiferal tests, after they were analyzed via LA-ICP-MS. Although flux outside of JFM is low, effort was made to sample individuals from all months to determine whether the isotopic composition of $G$. truncatulinoides varies with the annual cycle in SST and SSS. The $\delta^{18} \mathrm{O}$ of $G$. truncatulinoides is not significantly correlated with the seasonal cycle in monthly SST in the nGoM. In fact, the lowest (warmest) monthly median $\delta^{18} \mathrm{O}$ values in $G$. truncatulinoides occur in the coldest months (December-January). The $\delta^{18} \mathrm{O}$ ranges from $-0.66 \%$ to $-0.24 \%$ for 7 individuals in a single sample from one week in February 2013. This intra-sample range in $\delta^{18} \mathrm{O}$ variability represents $2 / 3$ of the annual range in monthly median $\delta^{18} \mathrm{O}$ values. The flux-weighted mean $\delta^{18} \mathrm{O}_{\mathrm{c}}$ for NC G. truncatulinoides is $-0.32( \pm 0.07)$ $\%$, with an overall range of $2.02 \%(-1.13 \%$ to $0.89 \%$ ). The fluxweighted mean $\delta^{18} \mathrm{O}_{\mathrm{c}}$ for $\mathrm{C} G$. truncatulinoides is $1.30( \pm 0.27) \%$, with a range of $1.56 \% 0(0.37 \% 0$ to $1.48 \%$ ) (Fig. 6) (Fig. S5, Supplementary materials).

There is no apparent seasonal cycle in the $\delta^{13} \mathrm{C}$ of $\mathrm{G}$. truncatulinoides. 


\section{ARTICLE IN PRESS}

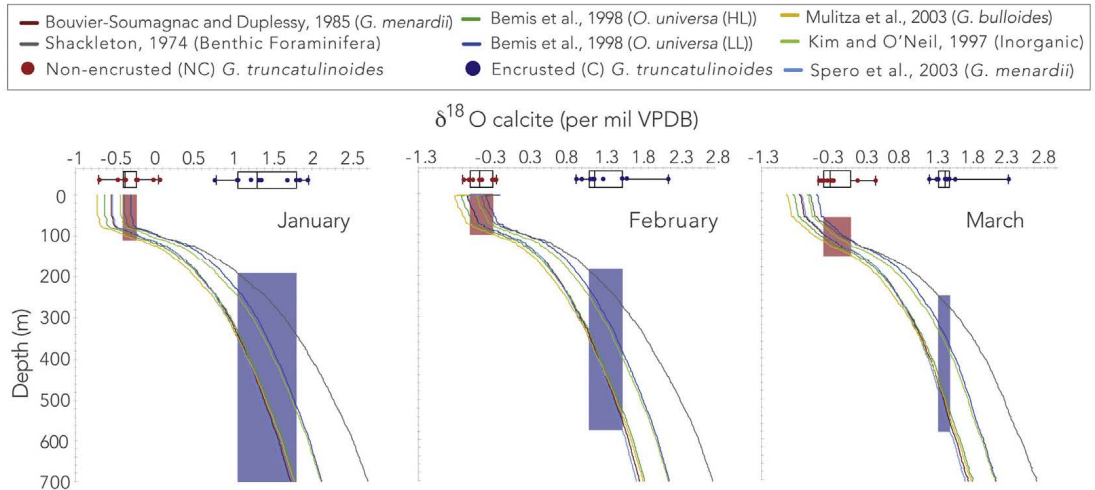

Fig. 7. January, February, and March calculated $\delta^{18} \mathrm{O}_{\mathrm{c}}$ profile comparisons of commonly used calcite-temperature relationship equations: Shackleton (1974) (benthic foraminifera) (grey), Kim and O'Neil (1997) (Inorganic) (light green), Bemis et al. (1998) (O. universa HL) (green), Bemis et al. (1998) (O. universa LL) (blue), Mulitza et al. (2003) (G. bulloides) (yellow), Spero et al. (2003) (G. menardii) (light blue), and Bouvier-Soumagnac and Duplessy (1985) (G. menardii) (dark red). Depth habitats of non-encrusted (red rectangles) and encrusted (blue rectangles) G. truncatulinoides based on calculated $\delta^{18} \mathrm{O}_{\mathrm{c}}$ are indicated. The colored circles (red $=\mathrm{NC}$ and blue $=\mathrm{C}$ ) represent the measured $\delta^{18} \mathrm{O}_{\mathrm{c}}$ plotted with the median, $\mathrm{IQR}$, and range for all measurements. Note the scale difference for each month. Note January encrusted values were truncated at $700 \mathrm{~m}$, the depth of our sediment trap. (For interpretation of the references to colour in this figure legend, the reader is referred to the web version of this article.)

Table 2

Equations used to determine calcification depths. [standards VSMOW: Vienna Standard Mean Ocean Water; and VPDB: Vienna Pee Dee Belemnite].

\begin{tabular}{llll}
\hline Reference & Species & $\mathrm{T}\left({ }^{\circ} \mathrm{C}\right)=$ & $\delta^{18} \mathrm{O}_{\mathrm{sw}}$ correction (VSMOW to VPDB) \\
\hline Bemis et al. (1998) (HL) & O. universa & $14.9-4.80\left(\delta^{18} \mathrm{O}_{\mathrm{c}}-\delta^{18} \mathrm{O}_{\mathrm{sw}}\right)$ & $-0.27 \%$ \\
Bemis et al. (1998) (LL) & O. universa & $16.5-4.80\left(\delta^{18} \mathrm{O}_{\mathrm{c}}-\delta^{18} \mathrm{O}_{\mathrm{sw}}\right)$ & $-0.27 \%$ \\
Bouvier-Soumagnac and Duplessy (1985) & G. menardii & $14.6-5.03\left(\delta^{18} \mathrm{O}_{\mathrm{c}}-\delta^{18} \mathrm{O}_{\mathrm{sw}}\right)$ & $-0.20 \%$ \\
Kim and O'Neil (1997) & Inorganic & $16.1-4.64\left(\delta^{18} \mathrm{O}_{\mathrm{c}}-\delta^{18} \mathrm{O}_{\mathrm{sw}}\right)$ & $-0.27 \%$ \\
Mulitza et al. (2003) & G. bultoides & $14.62-4.70\left(\delta^{18} \mathrm{O}_{\mathrm{c}}-\delta^{18} \mathrm{O}_{\mathrm{sw}}\right)$ & $-0.27 \%$ \\
Shackleton (1974) & Benthic Foraminifera & $16.9-4.0\left(\delta^{18} \mathrm{O}_{\mathrm{c}}-\delta^{18} \mathrm{O}_{\mathrm{sw}}\right)$ & $-0.20 \%$ \\
Spero et al. (2003) & G. menardii & $14.9-5.13\left(\delta^{18} \mathrm{O}_{\mathrm{c}}-\delta^{18} \mathrm{O}_{\mathrm{sw}}\right)$ & $-0.27 \%$ \\
\hline
\end{tabular}

The $\delta^{13} \mathrm{C}$ ranges from $-0.49 \%$ to $-0.22 \%$ for 7 individuals in a single sample from 1 week in February 2013. This intra-sample range in $\delta^{13} \mathrm{C}$ variability is nearly double the range in monthly median $\delta^{13} \mathrm{C}$ values. The flux-weighted mean $\delta^{13} \mathrm{C}_{c}$ for NC G. truncatulinoides is -0.42 ( \pm 0.07$) \%$, with an overall range of $1.14 \% 0$ ( $-0.76 \% 0$ to $0.38 \% 0)$. The flux-weighted mean $\delta^{13} \mathrm{C}_{c}$ for C G. truncatulinoides is $0.96( \pm 0.20) \%$, with a range of $1.39 \% 0(0.49 \%$ to $1.88 \%$ ) (Fig. 6) (Fig. S5, Supplementary materials)

\subsection{Determining depth habitat}

Globorotalia truncatulinoides is typically treated as a deep-dwelling planktic foraminifer for the purposes of downcore paleoceanographic studies (Matsumoto and Lynch-Stieglitz, 2003; Cléroux et al., 2009; Schmidt et al., 2003), with inferred depth habitat ranging from 100 to $800 \mathrm{~m}$ in the Atlantic Ocean. Direct observations of living specimens in plankton tow samples are sporadic, and thus conclusions regarding their depth habitat are based primarily on geochemical data. We demonstrate in this study that $\mathrm{C}$ and NC forms of $G$. truncatulinoides in the nGoM occupy distinct depth habitats, with the former reflecting deep subsurface waters, and the latter reflecting the surface mixed layer. It is important to remember that we assume $29 \%$ of the calcite of an encrusted specimen originated in the surface mixed layer.

We determine the calcification depths for both C and NC G. truncatulinoides in the nGoM using individual foraminiferal analyses (IFA) of $\delta^{18} \mathrm{O}_{c}$ by comparing the IFA $\delta^{18} \mathrm{O}_{c}$ with monthly vertical profiles of predicted $\delta^{18} \mathrm{O}_{c}$ in equilibrium with seawater (Fig. 7 and Fig. S6,
Supplementary materials). In order to do this, we use a suite of published $\delta^{18} \mathrm{O}$ paleotemperature equations to predict the foraminiferal $\delta^{18} \mathrm{O}_{\mathrm{c}}$ at different depths in the water column (Table 2). Vertical profiles of temperature and salinity from 18 CTD casts taken between 2008 and 2014 during sediment trap deployment/recovery cruises are available for each month, except December. For the month of December, we used the climatic mean profile from the Levitus et al. (2009) dataset (Antonov et al., 2010 and Locarnini et al., 2010), which is within 10 standard deviation of our CTD measurements for all other months. For months where multiple CTD casts were taken throughout the 9-year study period, temperature and salinity were averaged. Salinity was converted to $\delta^{18} \mathrm{O}$ of seawater $\left(\delta^{18} \mathrm{O}_{s \mathrm{w}}\right)$ using the equation,

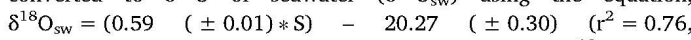
$p>.000001$ ), from paired measurements of salinity and $\delta^{18} \mathrm{O}_{\mathrm{SW}}$ at the nGoM sediment trap site (Fig. S7a and S7b, Supplementary materials).

Our results indicate that the NC form calcifies primarily within the surface mixed layer in JFM, during which $92 \%$ of $G$. truncatulinoides flux occurs. The flux-weighted mean depth determined for all NC $G$. truncatulinoides exported to the sediment is $66( \pm 9)$ meters, within the winter surface mixed layer. During the months of April through December, which only accounts for $8 \%$ of the NC annual flux, individuals have $\delta^{18} \mathrm{O}_{\mathrm{c}}$ values that indicate a slightly deeper calcification depth, within the seasonal thermocline $(50-170 \mathrm{~m})$. The $\delta^{18} \mathrm{O}_{\mathrm{c}}$ of the $\mathrm{C}$ form indicates the crust is added at a much deeper depth in the water column, with a flux-weighted average depth of $379( \pm 76)$ meters (Fig. 8). Without accounting for the contribution of mixed layer calcite, average flux weighted depth for an encrusted individual is only 


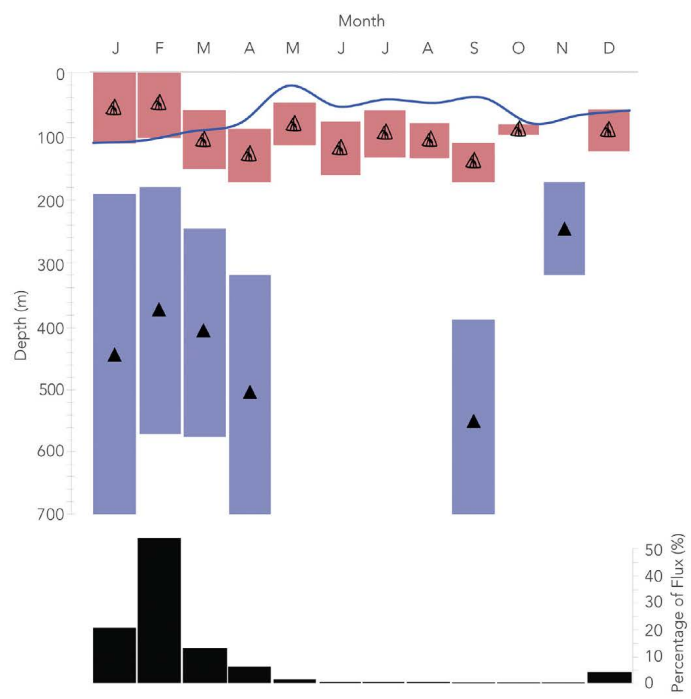

Fig. 8. Monthly depth habitats of non-encrusted (red) and encrusted (blue) $G$. truncatulinoides based on calculated and measured $\delta^{18} \mathrm{O}_{c}$. The triangle markers indicate the average depth for each month. The blue line represents the average thermocline depth based on our CTD profiles in the nGoM. Also plotted below (black bars) is the percentage of flux of both NC and $\mathrm{C}$ G. truncatulinoides in the sediment trap. Note there were no $\mathrm{C}$ measurements in May, June, July, August, October, and December and no NC measurements in November. The flux weighted average depth for NC is $66 \pm 9 \mathrm{~m}$ and $379 \pm 76 \mathrm{~m}$ for the $\mathrm{C}$ form. Note the C depths in January, April, and September were truncated at $700 \mathrm{~m}$ to align with the depth of our sediment trap. (For interpretation of the references to colour in this figure legend, the reader is referred to the web version of this article.)
$250 \pm 52 \mathrm{~m}, 129 \mathrm{~m}$ shallower. Corresponding depth ranges with CTD temperature is shown in Fig. S8, Supplementary materials. The total range of inferred calcification depths for individual C G. truncatulinoides is $170-700 \mathrm{~m}$, indicating that they are adding their calcite crust within or below the seasonal thermocline.

\section{5. $\mathrm{Mg} / \mathrm{Ca}-\mathrm{SST}$ relationship}

Using LA-ICP-MS to approximate $\mathrm{Mg} / \mathrm{Ca}$ of an entire foraminiferal test presents the challenge of inferring a whole test $\mathrm{Mg} / \mathrm{Ca}$ value from necessarily finite subsampling of a heterogeneous test. We demonstrate that values of $\mathrm{Mg} / \mathrm{Ca}$ representative of the whole shell can be calculated from the weighted mean of LA-ICP-MS data for the final three chambers of an individual foraminifer (see Section 3.3 and Fig. S2, Supplementary materials). We also demonstrate that the LA-ICP-MS Mg/Ca values based on individual NC foraminifera are within $1 \sigma$ of solution-based $\mathrm{Mg} / \mathrm{Ca}$ within the sediment trap sample set (Fig. 11). Therefore, we suggest that using the weighted mean $\mathrm{Mg} / \mathrm{Ca}$ based on LA-ICP-MS of at least the final three chambers of $G$. truncatulinoides is an appropriate representation of whole foraminifer $\mathrm{Mg} / \mathrm{Ca}$ in this section.

Existing $\mathrm{Mg} / \mathrm{Ca}$-temperature relationships for $\mathrm{G}$. truncatulinoides are based on a sediment trap data set from the Sargasso Sea (Anand et al., 2003), and core-top studies from the Indian Ocean (McKenna and Prell, 2004), the mid-Atlantic Ocean (Cléroux et al., 2013), and the Caribbean and Tropical Atlantic Ocean (Regenberg et al., 2009). Only McKenna and Prell, 2004 analyzed encrusted and non-encrusted individuals separately, whereas other studies did not discriminate.

We generate a new $\mathrm{Mg} / \mathrm{Ca}$-temperature equation for $\mathrm{G}$. truncatulinoides using 123 paired $\mathrm{Mg} / \mathrm{Ca}-\delta^{18} \mathrm{O}$ IFA from a 4-year sediment trap time series. We do so by regressing weighted mean $\mathrm{Mg} / \mathrm{Ca}$ (with $\mathrm{Mg} / \mathrm{Ca}$ of encrusted specimens corrected for contribution of lamellar calcite) against $\delta^{18} \mathrm{O}$ calcification temperature for the entire data set over a temperature range of $6-27^{\circ} \mathrm{C}$. We use the spero et al. (2003) G. menardii equation to derive $\delta^{18} \mathrm{O}$ calcification temperature and assume distinct $\delta^{18} \mathrm{O}_{\mathrm{sw}}$ for $\mathrm{C}$ and $\mathrm{NC}$ at their respective mean depth habitats of $400 \mathrm{~m}$ and $75 \mathrm{~m}(0.46 \pm 0.22$ for $\mathrm{C}$ and $1.16 \pm 0.09$ for NC). Fig. 9

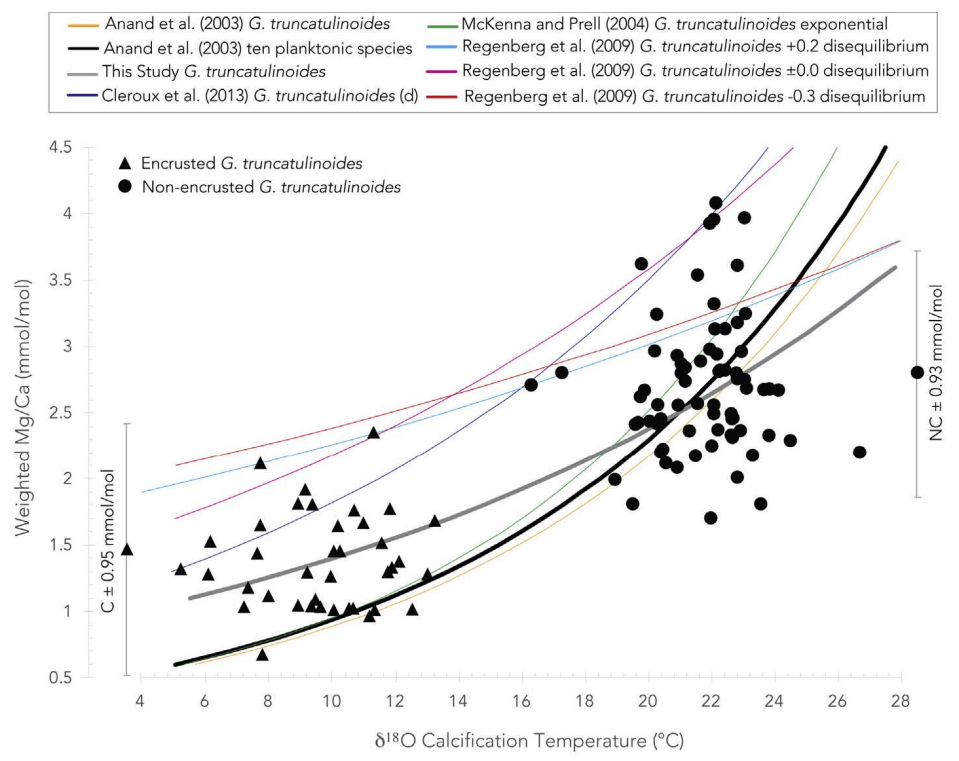

Fig. 9. Weighted $\mathrm{Mg} / \mathrm{Ca}(\mathrm{mmol} / \mathrm{mol})$ vs. calcification temperature $\left({ }^{\circ} \mathrm{C}\right)$ plot of encrusted (black triangles) and non-encrusted (black circles) G. truncatulinoides. Encrusted $\mathrm{Mg} / \mathrm{Ca}$ in this figure has been corrected for the contribution of lamellar calcite. All reported temperature values were calculated using $\delta^{18} \mathrm{O}$ calcification temperature equation from Spero et al. (2003), and assuming a $\delta^{18} \mathrm{O}_{\mathrm{sw}}$ of $1.16 \pm 0.09$ for $\mathrm{NC}$ and $0.46 \pm 0.22$ for $\mathrm{C} \delta^{18} \mathrm{O}_{\mathrm{sw}}$ based on average measured values from the sediment trap location at $75 \mathrm{~m}(\mathrm{NC})$ and $400 \mathrm{~m}(\mathrm{C}) . \mathrm{Mg} / \mathrm{Ca}$ temperature equations plotted are: McKenna and Prell (2004) exponential equation (green), Anand et al. (2003) G. truncatulinoides (yellow), Anand et al (2003) ten planktonic species (black), Cléroux et al (2013) (dark blue), Regenberg et al. (2009) + 0.2 (light blue), Regenberg et al. (2009) \pm 0.0 (pink), Regenberg et al. (2009) -0.3 (orange), and our own calculated exponential equation (grey). $\mathrm{Mg} / \mathrm{Ca}$ errors are \pm 0.95 and $\pm 0.93 \mathrm{mmol} / \mathrm{mol}$, for $\mathrm{C}$ and NC respectively RMS errors detailed in Section 5.5. (For interpretation of the references to colour in this figure legend, the reader is referred to the web version of this article.) 
Table 3

Calibration equations. Anand et al. (2003) ten planktonic species include: G. ruber (white), G. ruber (pink), G. sacculifer, G. conglobatus, G. aequilateralis, O. universa, N. dutertrei, P. obliquiloculata, G. inflata, G. truncatulinoides, G. hirsuta, G. crassaformis.

\begin{tabular}{|c|c|c|c|c|}
\hline Reference: & Species: & $\mathrm{Mg} / \mathrm{Ca}(\mathrm{mmol} / \mathrm{mol})=$ & & Temperature Range $\left({ }^{\circ} \mathrm{C}\right)$ \\
\hline Anand et al. (2003) & ten planktonic species & $0.38( \pm 0.02) * \mathrm{e}^{\left(0.09( \pm 0.003)_{*} \mathrm{~T}\right)}$ & $r=0.93$ & $13-28$ \\
\hline Anand et al. (2003) & G. truncatulinoides & $0.359( \pm 0.008) * \mathrm{e}^{\left(0.09_{*} \mathrm{~T}\right)}$ & & $16-18$ \\
\hline Cléroux et al. (2013) & G. truncatulinoides (d.) & $0.938( \pm 0.03) * \mathrm{e}^{\left(0.066( \pm 0.007)_{*} \mathrm{~T}\right)}$ & $r^{2}=0.59$ & $8-16$ \\
\hline McKenna and Prell (2004) & G. truncatulinoides & $0.355( \pm 0.05) * \mathrm{e}^{\left(0.098( \pm 0.008)_{*} \mathrm{~T}\right)}$ & $r^{2}=0.92$ & $6-23$ \\
\hline Regenberg et al. (2009) & G. truncatulinoides (d.) +0.2 disequilibrium $(\%)$ & $1.69( \pm 0.11) * \mathrm{e}^{\left(0.029( \pm 0.008)_{*} \mathrm{~T}\right)}$ & $r=0.45$ & 9-15 \\
\hline Regenberg et al. (2009) & G. truncatulinoides (d.) \pm 0.0 disequilibrium (\%) & $1.32( \pm 0.12) * \mathrm{e}^{\left(0.05( \pm 0.009)_{*} \mathrm{~T}\right)}$ & $r=0.59$ & 9-15 \\
\hline Regenberg et al. (2009) & G. truncatulinoides (d.) -0.3 disequilibrium (\%) & $1.84( \pm 0.09) * \mathrm{e}^{\left(0.026( \pm 0.007)_{*} \mathrm{~T}\right)}$ & $r=0.46$ & $9-15$ \\
\hline Eq. (2), this study & G. truncatulinoides & $0.818( \pm 0.01) * \mathrm{e}^{\left(0.054( \pm 0.005)_{*} \mathrm{~T}\right)}$ & $r^{2}=0.66$ & $6-27$ \\
\hline
\end{tabular}

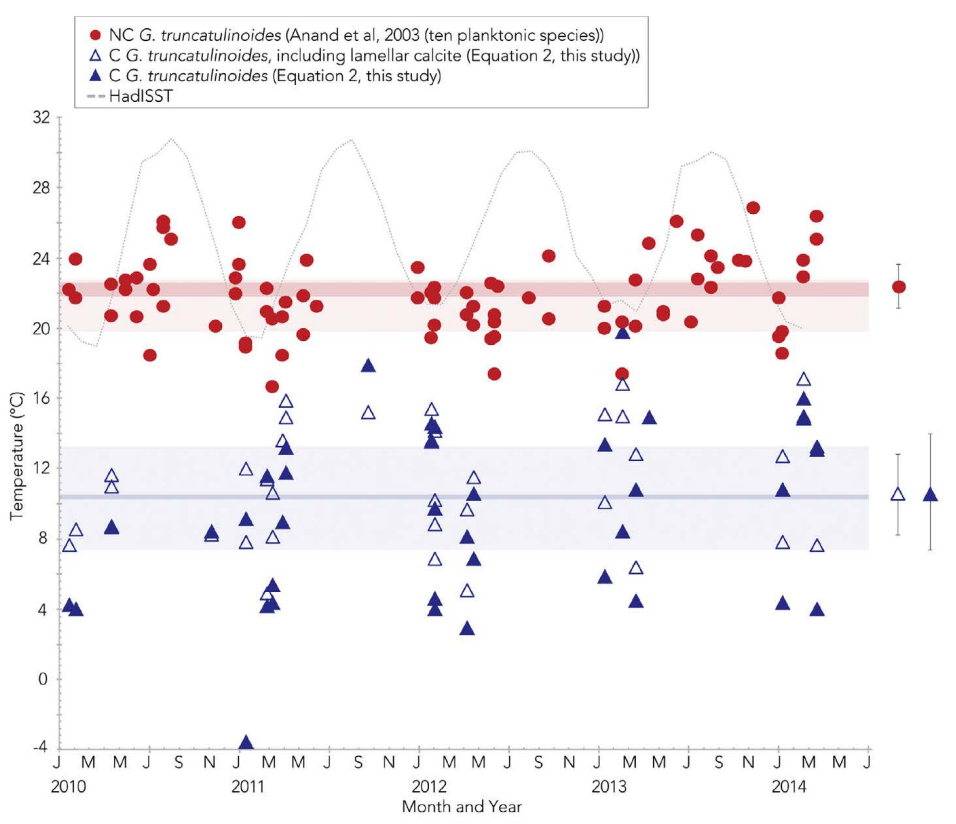

Fig. 10. $\mathrm{Mg} / \mathrm{Ca}$-temperature $\left({ }^{\circ} \mathrm{C}\right)$ reconstructed using Eq. (2), this study, for encrusted (closed blue triangles) and Anand et al., 2003 (ten planktonic species) for non-encrusted (closed red circles). The open blue triangles indicate $\mathrm{Mg} / \mathrm{Ca}$-SST that included lamellar calcite also calculated with Eq.(2), this study. The grey dotted line is monthly averaged HadISST $1 \times 1$ gridded data at $27.5^{\circ} \mathrm{N} 90.3^{\circ} \mathrm{W}$. Error bars represent the pooled average $95 \%$ confidence interval calculated using PSU Solver (Thirtumalai et al., 2016). Error bar values are NC $(+1.32$ and -1.19$), \mathrm{C}(+1.32$ and -1.19$)$, and $\mathrm{C}$ including lamellar calcite $(+2.29$ and -2.30$)$. The light red shaded area is the average CTD temperature $21.3 \pm 1.5^{\circ} \mathrm{C}$ from January, February, and March (JFM) at the NC depth range $0-150 \mathrm{~m}$. The dark red shaded area is average JFM temperature, $22.2 \pm 0.4{ }^{\circ} \mathrm{C}$ from $66 \mathrm{~m}$ (the average flux weighted depth for NC G. truncatulinoides). The light blue shaded area is the average CTD temperature $10.3 \pm 3.0^{\circ} \mathrm{C}$ from January, February, and March (JFM) at the $\mathrm{C}$ depth range $170-700 \mathrm{~m}$. The dark blue shaded area is average JFM temperature, $10.4 \pm 0.1^{\circ} \mathrm{C}$ at $379 \mathrm{~m}$ (the average flux weighted depth for $C$ G. truncatulinoides). (For interpretation of the references to colour in this figure legend, the reader is referred to the web version of this article.)

shows the new exponential $\mathrm{Mg} / \mathrm{Ca}$-temperature relationship (Eq. 1, $r^{2}=0.66, p<.0001$ ) for this study, with all published relationships shown for reference (Table 3 ).

$\mathrm{Mg} / \mathrm{Ca}(\mathrm{mmol} / \mathrm{mol})=0.818( \pm 0.01) \mathrm{e}^{(0.0543( \pm 0.005) * \mathrm{~T})}$

Eq. (2) is, by far, the best fit for the encrusted data from this study, and we use it to calculate temperature from $\mathrm{Mg} / \mathrm{Ca}$ for encrusted $G$. truncatulinoides wherever $\mathrm{Mg} / \mathrm{Ca}$-SST estimates are given. However, there is evidence from culture studies (Davis et al., 2017) and sediment trap studies (Jonkers et al., 2016) that in other non-spinose foraminifera the $\mathrm{Mg} / \mathrm{Ca}$ of the crust is lower than that of lamellar calcite formed at the same temperature. Therefore, it may not be appropriate to formulate a single equation based on both NC and C G. truncatulinoides. An alternative would be to make two separate equations, for $\mathrm{C}$ and $\mathrm{NC}$, but this did not yield significant exponential or linear relationships between $\mathrm{Mg} / \mathrm{Ca}$ and calcification temperature for this dataset $\left(r^{2}=0.007\right.$ (NC) and $0.0059(\mathrm{C})$ for exponential equations). This is due, in part, to large scatter in the single foraminifera $\mathrm{Mg}$ / $\mathrm{Ca}$ data and to the limited calcification temperature ranges for $\mathrm{C}$ and $\mathrm{NC}$.

Because NC G. truncatulinoides is of far greater interest than $\mathrm{C}$ for paleoceanographic reconstruction of winter mixed layer temperatures, we focus now on the best $\mathrm{Mg} / \mathrm{Ca}$-temperature relationship for $\mathrm{NC}$. We compared the $\mathrm{Mg} / \mathrm{Ca}$ residuals between this data set and the three best fit exponential equations on our data: Anand et al., 2003, based on ten planktonic species (hereafter, Anand-All), McKenna and Prell (2004), and Eq. (2) (this study) (Fig. S9, Supplementary materials). Whereas Eq. (2) has the lowest residuals overall, the Anand-All $(\mathrm{Mg} / \mathrm{Ca}(\mathrm{mmol} /$ $\left.\mathrm{mol})=0.38( \pm 0.02) \mathrm{e}^{\left(0.09( \pm 0.003)_{*} \mathrm{~T}\right)}\right)$ has equally low residuals for the non-encrusted data set $(95 \%$ of $\mathrm{Mg} / \mathrm{Ca}$ determinations for $\mathrm{NC}$ fall within $2 \sigma$ of predicted $\mathrm{Mg} / \mathrm{Ca}$ using both equations). In terms of mean flux-weighted $\mathrm{Mg} / \mathrm{Ca}-\mathrm{SST}$ estimates for the sediment trap time series, Eq. (2) and Anand-All return nearly identical values $\left(21.5 \pm 3.4^{\circ} \mathrm{C}\right.$ and $21.3 \pm 3.4^{\circ} \mathrm{C}$, respectively). To compare how these two equations perform in down core temperature reconstructions, we applied them both to a NC G. truncatulinoides $\mathrm{Mg} / \mathrm{Ca}$ data set from the Pigmy Basin in the northern GoM (from Spear et al., 2011). Eq. (2) implies a winter mixed layer warming trend of $5.4^{\circ} \mathrm{C}$ over the past century, whereas Anand-All returns a much smaller trend of $3.2^{\circ} \mathrm{C}$ over the same interval (Fig. S10, Supplementary materials). Both estimates are larger than expected from the observational record (e.g., the DJF and MAM warming over the past century from HadISST in the nGoM is $<0.5^{\circ} \mathrm{C}$ ), 


\section{ARTICLE IN PRESS}

but additional proxies in the same sediment core (TEX ${ }_{86}$-SST and $\mathrm{Mg}$ / Ca-SST G. ruber) also show larger trends $\left(1.1^{\circ} \mathrm{C}\right.$ and $1.4^{\circ} \mathrm{C}$, respectively) than HadISST over the past century (Richey et al., 2011; Richey and Tierney, 2016). Winter SSTs, which $G$. truncatulinoides is reflecting, have much larger (by a factor of 3) inter-annual variance than summer or mean annual SST in the nGoM. Given the unrealistically large down core temperature variations implied by Eq. (2), we recommend using Anand-All for $\mathrm{NC} \mathrm{Mg} / \mathrm{Ca}$-paleotemperature reconstructions. Throughout the remainder of this paper, Anand-All is used to convert $\mathrm{NC} \mathrm{Mg} / \mathrm{Ca}$ to temperature.

The flux-weighted mean $\mathrm{Mg} / \mathrm{Ca}$-derived temperature exported from the water column over the 4-year sampling interval for NC individuals is $21.3^{\circ} \pm 3.4^{\circ} \mathrm{C}$ (using Anand-All), and for encrusted individuals is $8.8^{\circ} \pm 1.6^{\circ} \mathrm{C}$ (using Eq. (2)). These estimates are within $1 \sigma$ of the observed flux-weighted temperatures for their respective depth ranges: $0-150 \mathrm{~m}$ mean temperature $\left(21.3 \pm 3.3^{\circ} \mathrm{C}\right)$ and $170-700 \mathrm{~m}$ mean temperature $\left(10.6{ }^{\circ} \mathrm{C} \pm 1.6^{\circ} \mathrm{C}\right.$ ) (Fig. 10). Some studies have concluded that temperatures dropping below $16^{\circ} \mathrm{C}$ triggers crust formation (Hemleben et al., 1985; Cléroux et al., 2007; Regenberg et al., 2009), which is consistent with our mean encrusted calcification temperature of $8.8^{\circ} \mathrm{C}\left( \pm 1.6^{\circ} \mathrm{C}\right)$. We also do not observe $\mathrm{Mg} / \mathrm{Ca}$-temperature estimate below $16^{\circ} \mathrm{C}$ for any NC individual in this study. Despite the excellent agreement between the mean $\mathrm{Mg}$ /Ca-derived temperature and the observed winter mixed layer temperature in the nGoM, NC G. truncatulinoides $\mathrm{Mg} / \mathrm{Ca}$ does not vary with the annual cycle. This could simply result from under sampling the extremely low-flux summer months. More likely, it is due to the subsurface depth habitat of the NC population in non-winter months (April-December, Fig. 8). Another subsurface temperature proxy from our sediment trap time series, $\mathrm{TEX}_{86}$, correlates well to mean annual SST but does not vary with SST seasonally (Richey and Tierney, 2016). This is not surprising given the muted seasonal cycle in the subsurface (e.g. annual temperature range at $75 \mathrm{~m} 2{ }^{\circ} \mathrm{C}$ ) (Levitus et al., 2009).

Paired $\mathrm{Mg} / \mathrm{Ca}-\delta^{18} \mathrm{O}$ determinations on $\mathrm{G}$. truncatulinoides have not been used to calculate both temperature and $\delta^{18} \mathrm{O}_{\mathrm{sw}}$ in previous studies, most likely because of the ambiguous depth habitat of this species. Since we have paired measurements on individual foraminifera here, we derive $\delta^{18} \mathrm{O}_{s w}$ using the Spero et al. (2003) eq. (G. menardii) and the $\mathrm{Mg} / \mathrm{Ca}$-derived temperatures using the Anand-All $\mathrm{Mg} / \mathrm{Ca}$-temperature equation. The resulting flux-weighted $\delta^{18} \mathrm{O}_{\mathrm{sw}}$ for NC individuals is $1.08 \%$ ( $\pm 0.18 \%$ ), which is nearly identical to flux-weighted $\delta^{18} \mathrm{O}_{s w}$ measurements $(1.10 \pm 0.17 \%$ ) from water samples in the upper $150 \mathrm{~m}$ from $18 \mathrm{CTD}$ casts at the sediment trap site. This suggests that this combination of equations may be used to derive temperature and $\delta^{18} \mathrm{O}_{\mathrm{sw}}$ from paired $\mathrm{Mg} / \mathrm{Ca}-\delta^{18} \mathrm{O}$ in NC $G$. truncatulinoides for down core reconstructions of winter mixed layer conditions.

Overall, the flux-weighted mean $\mathrm{Mg} / \mathrm{Ca}$ data derived from LA-ICPMS analyses on individual NC G. truncatulinoides yields values that are consistent with solution-based $\mathrm{Mg} / \mathrm{Ca}$ measurements in co-occurring samples. For example, 34 aliquots of $G$. truncatulinoides (15-30 individuals, $300-425 \mu \mathrm{m}$ size fraction) from this sediment trap time series (including data from Spear et al., 2011) have been analyzed via solution-based ICP-OES. These solution-based analyses were exclusively from winter sediment trap samples (Jan-Mar, 2008-2014), and resulted in a mean $\mathrm{Mg} / \mathrm{Ca}$ of $3.01( \pm 0.30,1 \sigma) \mathrm{mmol} / \mathrm{mol}$. The mean $\mathrm{Mg} / \mathrm{Ca}$ of 76 individual NC G. truncatulinoides $(>300 \mu \mathrm{m})$, determined via weighted LA-ICP-MS analyses from the same sediment trap time series is $2.75( \pm 0.56,1 \sigma) \mathrm{mmol} / \mathrm{mol}$. We did paired solution-based and laser ablation analyses on six winter sediment trap samples with sufficient number of individuals (Fig. 11). Whereas the mean solution-based and laser ablation $\mathrm{Mg} / \mathrm{Ca}$ values for the six NC samples are within $1 \sigma$ error of one another $(3.08 \pm 0.27$ and $2.65 \pm 0.25 \mathrm{mmol} / \mathrm{mol}$, respectively), the solution-based mean $\mathrm{Mg} / \mathrm{Ca}$ values for $\mathrm{C}$ samples are higher than laser ablation-derived mean $\mathrm{Mg} / \mathrm{Ca} \quad(2.02 \pm 0.16$ and $1.54 \pm 0.23 \mathrm{mmol} / \mathrm{mol}$, respectively). The observed lower $\mathrm{Mg} / \mathrm{Ca}$ for LA-ICP-MS derived measurement may result from under sampling the

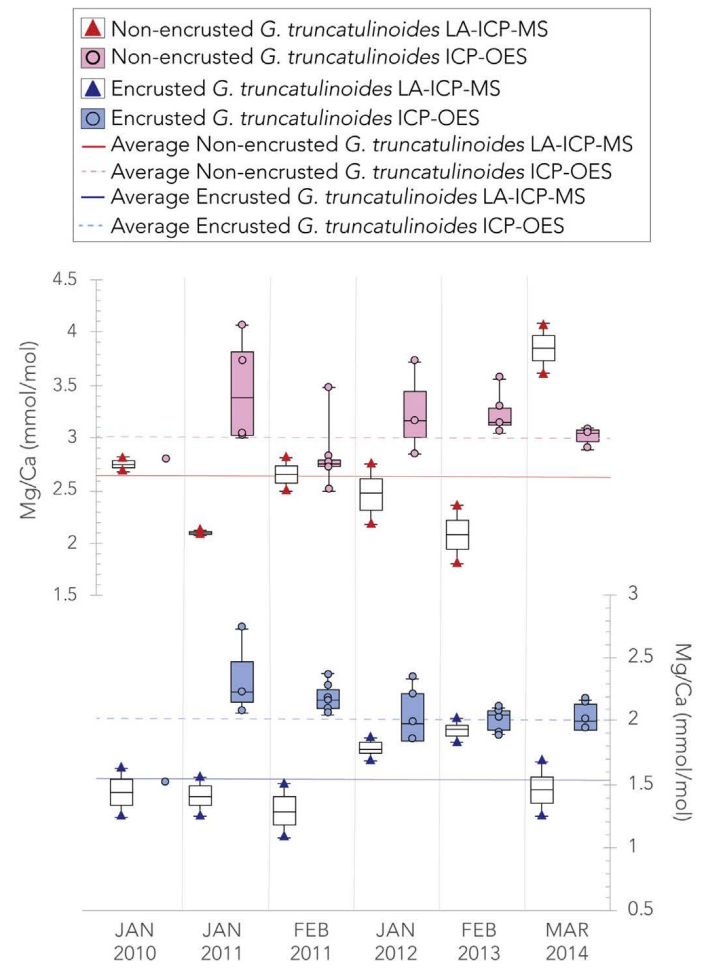

Fig. 11. Non-encrusted G. truncatulinoides $\mathrm{Mg} / \mathrm{Ca}(\mathrm{mmol} / \mathrm{mol})$ median, $\mathrm{IQR}$, and ranges measured on the ICP-OES (pink circles) plotted alongside the weighted $\mathrm{Mg} / \mathrm{Ca}(\mathrm{mmol} / \mathrm{mol})$ median, $\mathrm{IQR}$, and ranges measured on the LAICP-MS (red triangles). The red solid line indicates the mean $\mathrm{Mg} / \mathrm{Ca}$ of $\mathrm{NC}$ via LAICP-MS $2.65( \pm 0.25) \mathrm{mmol} / \mathrm{mol}$ and the pink dashed line indicates the mean $\mathrm{Mg} / \mathrm{Ca}$ from NC ICP-OES, $3.08( \pm 0.7) \mathrm{mmol} / \mathrm{mol}$. Also plotted are encrusted G. truncatulinoides $\mathrm{Mg} / \mathrm{Ca}(\mathrm{mmol} / \mathrm{mol})$ median, $\mathrm{IQR}$, and ranges measured on the ICP-OES (blue circles) plotted alongside the weighted $\mathrm{Mg} / \mathrm{Ca}$ $(\mathrm{mmol} / \mathrm{mol})$ median, IQR, and ranges measured on the LA-ICP-MS (blue triangles). The blue solid line indicates the mean $\mathrm{Mg} / \mathrm{Ca}$ of $\mathrm{C}$ via LA-ICP-MS 1.54 $( \pm 0.23) \mathrm{mmol} / \mathrm{mol}$ and the light blue dashed line indicates the mean $\mathrm{Mg} / \mathrm{Ca}$ from C ICP-OES, $2.02( \pm 0.16) \mathrm{mmol} / \mathrm{mol}$. Plotted on the $\mathrm{x}$-axis is the month and year the sediment trap samples were collected. The $\mathrm{Mg} / \mathrm{Ca}$ values for the ICP-OES were drift corrected (Schrag, 1999). The encrusted individuals were not corrected for lamellar calcite in this figure to better compare ICP-OES measurements with LA-ICP-MS measurements. (For interpretation of the references to colour in this figure legend, the reader is referred to the web version of this article.)

lamellar calcite when using the laser. We used a higher laser repetition rate and longer dwell time on encrusted individuals, resulting in a loss of sampling resolution of the inner test wall (lamellar calcite), and failure to capture high $\mathrm{Mg} / \mathrm{Ca}$ banding that we observed in the test wall of $\mathrm{NC}$ individuals.

Although LA-ICP-MS and solution-based $\mathrm{Mg} / \mathrm{Ca}$ analysis yield comparable results, we must emphasize that laser based analysis for paleoceanographic reconstruction needs to be applied to a large sample size ( $>10$ individuals) in order to obtain meaningful environmental information on a population. The pooled standard deviation among all $\mathrm{Mg} / \mathrm{Ca}$ determinations where multiple NC individuals were analyzed from the same sample cup is $0.37 \mathrm{mmol} / \mathrm{mol}$, which is slightly higher than the standard deviation of all winter solution-based measurements $(0.30 \mathrm{mmol} / \mathrm{mol})$ 


\section{ARTICLE IN PRESS}

\section{Conclusions}

Using the geochemistry of individual foraminifera from a sediment trap time series in the nGoM, we determined that the encrusted and non-encrusted forms of $G$. truncatulinoides calcify in distinct depth habitats in the upper ocean. If care is taken to discriminate between the two forms for down core studies, the non-encrusted form can be used to reconstruct winter surface mixed layer conditions in the nGoM. Oxygen isotopes of individual foraminifera indicate a mean calcification depth for NC G. truncatulinoides of $66( \pm 9)$ meters, within the surface mixed layer. The mean depth represented by encrusted specimens is 379 ( \pm 76 ) meters, assuming $29 \%$ of the calcite of an encrusted specimen originates in the winter mixed layer.

LA-ICP-MS Mg/Ca values based on the weighted mean for an individual foraminifer are not significantly different from solution-based $\mathrm{Mg} / \mathrm{Ca}, 2.75 \pm 0.56 \mathrm{mmol} / \mathrm{mol}$ and $3.01 \pm 0.30 \mathrm{mmol} / \mathrm{mol}$, respectively. When using LA-ICP-MS, the weighted mean of the final three chambers (F, F1, and F2) is an acceptable method for approximating the $\mathrm{Mg} / \mathrm{Ca}$ of a whole foraminifer test. NC G. truncatulinoides have a fluxweighted temperature $21.3^{\circ} \pm 3.4^{\circ} \mathrm{C}$ using Anand et al., 2003 (ten planktonic species) equation, which is identical to the $0-150 \mathrm{~m}$ fluxweighted temperature at the sediment trap site $\left(21.3 \pm 3.3^{\circ} \mathrm{C}\right)$ from CTD observations.

\section{Acknowledgements}

We thank Eric Tappa, Kaustubh Thirumalai, and the LUMCON crew of the RV Pelican for ongoing maintenance of the sediment trap mooring. Thanks to Jennifer Flannery and Edward Chu for assistance with geochemical analysis, and Oscar Branson for data analysis assistance. We thank two anonymous reviewers for their constructive comments on this manuscript. This research was supported by the USGS Climate and Land Use Research and Development Program. Any use of trade, firm, or product names is for descriptive purposes only and does not imply endorsement by the U.S. Government. All new data presented in this study can be accessed in the USGS Data Release (Reynolds et al., 2018), https://doi.org/10.5066/F72806W4.

\section{Appendix A. Supplementary data}

Supplementary data to this article can be found online at https:// doi.org/10.1016/j.marmicro.2018.05.006.

\section{References}

Anand, P., Elderfield, H., Conte, M.H., 2003. Calibration of Mg/Ca thermometry in planktonic foraminifera from a sediment trap time series. Paleoceanograthy 18 to. 2 Antonov, J.I., Seldov, D., Boyer, T.P., Locarniti, R.A., Mishonov, A.V., Garcia, H.E., Baranova, O.K., Zweng, M.M., Johnson, D.R., 2010. World Ocean Atlas 2009. Vol. 2 US Government Printing Office, Salinity Washington DC (NOAA Atlas NESDIS 69 , 184 p).

Bemis, B.E., Spero, H.J., Bijma, J., Lea, D.W., 1998. Reevaluation of the oxygen isotopic composition of planktonic foraminifera: experimental results and revised paleo temperature equations. Paleoceanography $13,150-160$ no. 2

Billups, K., Hudson, C., Kunz, H., Rew, I., 2016. Exploring Globorotalia truncatulinoides coiling ratios as a proxy for subtropical gyre dynamics in the northwestern Atlantic Ocean during late Fleistocene Ice Ages. Paleoceanography 31 (5), 553-563.

Bouviersoumagnac; Y., Duplessy, J.C., 1985. Carbon and oxygen isotopic composition of planktonic-foraminifera from laboratory culture, plankton tows and recent sedimentimplications for the reconstruction of Paleoclimatic conditions and of the global carbon-cycle. J. Foraminifer. Res. 15 (4), 302-320.

Caromel, A.G.M., Schmidt, D.N., Fletcher, I., Rayfield, E.J., 2016. Morphological change during the ontogeny of the Planktic foraminifera. J. Micropalaentol. 35, 2-19.

Cléroux, C., Cortijo, E., Duplessy, J.C., Zahn, R., 2007. Deep-dwelling foraminifera as thermocline temperature recorders. Geochem. Geothys, Geosyst 8 .

Cléroux, C., Cortijo, E., Anand, P., Labeyrie, L., Bassinot, F., Caillon, N., Duplessy, J., $2008 \mathrm{Mg} / \mathrm{Ca}$ and $\mathrm{Sr} / \mathrm{Ca}$ ratios in plakntonic foramnifiera: Proxies for upper water
column temperrautre reconstruction: Paleoceanography. 23 PA32d14. https://doi. org/10.1029/2007PA001505.

Cléroux, C., Lynch-Stieglitz, J., Schmidt, M.W., Cortijo, E., Duplessy, J.C., 2009. Evidence for calcification depth change of Globorotalia truncatulinoides between deglaciation and Holocene in the western Atlantic Ocean. Mar. Micropaleontol. 73 (1-2), 57-61.
Cléroux, C., deMenocal, P., Arbuszewski, J., Linsley, B., 2013. Reconstructing the upper water column thermal structure in the Atlantic Ocean. Paleoceanography 28 (3), 503-516.

Davis, C.V., Fehrenbacher, J.S., Hill, T.M., Russell, A.D., Spero, H.J., 2017. Relationships between temperature, $\mathrm{pH}$, and crusting on $\mathrm{Mg} / \mathrm{Ca}$ ratios in laboratory-grown Neogloboquadrina foraminifera. Paleoceanography 32, 1137-1152 10.1002.2017PA003111.

Deuser, W.G., Ross, E.H., 1989. Seasonally abundant planktonic-foraminifera of the Sargasso Sea - succession, deep-water fluxes, isotopic compositions, and Paleoceanographic implications. J. Foraminifer. Res. 19 (4), 268-293.

Duckworth, D.L., 1977. Magnesium concentration in the tests of the planktonic for aminifer Globorotalia truncatulinoides. J. Foraminifer. Res. 7 (4), 304-312.

Dukhovskoy, D., Leben, R., Chassignet, E., Hall, C., Morey, S., Nedbor-Gross, R., 2015 Charicterixation of the uncertaitnty of loop current metrics using a multidecal nu merical simulation and altimeter observations. Deep Sea Research I 100, 140-158. http://dx.doi.org/10.1016/j.dst.2015.01.005.

Eggins, S., De Deckker, P., Marshall, J., 2003. Mg/Ca variation in planktonic foraminifera tests: implications for reconstructing palaeo-seawater temperature and habitat migration. Earth Planet. Sci. Lett. $212(3-4), 291-306$.

Fairbanks, R.G., Wiere, P.H., Be, A.W.H., 1980. Vertical distribution and isotopic composition of Livivng planktonic Foramninifera in the western North Atlantic. Science $207(4426), 61-63$.

Fehrenbacher, J.S., Spero, H.J., Russell, A.D., Vetter, L., Eggins, S., 2015. Optimizing LA. ICP-MS Analytical Procedures for Elemental Depth Profiling of Foraminifera Shells: Chemical Geology. Vol. 407. pp. 2-9.

Feldmeijer, W., Metcalfe, B., Brummer, G.J.A., Ganssen, G.M., 2015. Reconstructing the depth of the permanerit themocline through the morphology and geochemistry of the deep dwelling planktonic foraminifer Globorotalia truncatulinoides. Paleoceanography $30(1), 1-22$

Gibson, K.A., Thunell, R.C., Machain-Castillo, M.L., Fehrenbacher, J., Spero, H.J., Wejnert, K., Nava-Fernández, X., Tappa, E.J., 2016. Evaluating controls on planktonic foraminiferal geochemistry in the Eastern Tropical North Pacific. Earth Planet. Sc. Lett. 452, 90-103.

Healy-Williams, N., Ehrlich, R., Williams, D.F., 1985. Morphometric and stable isotopic vidence for subpopulations of Globorotalia-Truncatulinoides. J. Foraminifer. Res. 15 (4), 242-253.

Hernleben, C., 1975. Spine and pustule relationships in some recent planktonic foraminifera. Mictopalentology 21 (3), 334-341 (pls. 1-2).

Hemleben, C., Spindler, M., Breitinger, I., Deuser, W.G., 1985. Field and laboratory studies on the ontogeny and ecology of some Globorotalid species from the Sargasso Sea off Bermuda. J. Foraminifer. Res. 15 (4), 254-272.

Huang, H.S., Walker, N.D., Hsueh, Y., Chao, Y., Leben, R.R., 2013. An analysis of loop current frontal eddies in a $1 / 6^{\circ}$ Atlantic Ocean model simulation. J. Phys. Oceanogr. 43 (9), 1924-1939. http://dx.doi.org/10.1175/JPO-D-12-0227.1.

Jian, Z.M., Li, B.H., Huang, B.O., Wang, J.L., 2000. Globorotalia truncatulinoides as indicator of upper-ocean thermal structure during the quaternary: evidence from the South China Sea and okinawa trough. Palaeogeogr. Palaeoclimatol. Palaenecol. 162 (3-4), 287-298.

Jonkers, L., de Nooijer, L.J., Reichart, G.J., Zahn, R., Brummer, G.J.A., 2012. Encrustation and trace element composition of Neogloboquadrina dutertrei assessed from single chamber analyses - implications for paleotemperature estimates. Biogeosciences 9 (11), 4851-4860

Jonkers, L., Reynolds, C.E., Richey, J., Hall, I.R., 2015. Lunar periodicity in the shell flux of plathitonic foraminifera in the Gulf of Mexico. Biogeosciences 12 (10), 3061-3070.

Jonkers, L., Buse, B., Brummer, G.-J., Hall, I.R., 2016. Chamber formation leads to $\mathrm{Mg} / \mathrm{C}$ banding in the planktonic foraminifer Neogloboquadrina pachyderma. Earth Planet. Sci. Lett. 451, 177-184. http://dx.dol.org/10.1016/j.epsl.2016.07.030.

Kennett, J.F., 1968. Globorotalia truncatulinoides as a paleo-oceanographic index. Science 159, 1461-1462.

Kim, S.T., O'Neil, J.R., 1997. Equilibrium and nonequilibrium oxygen isotope effects in synthetic carbonates. Geochitm. Cosmochim. Acta 61 (16), 3461-3475.

LeGrande, A.N., Lynch-Stieglitz, J., 2007. Surface currents in the western North Atlantic during the last glacial maximum. Geochem. Geophys. Geosyst. 8.

LeGrande, A.N., Lynch-Stieglitz, J., Farmer, E.C., 2004. Oxygen Isotopic Composition of Globorotalia Truncatulinoides as a Proxy for Intermediate Depth Density: Paleoceanography. Vol. 19 no. 4.

Levitus, S., Antonov, J.I., Boyer, T.P., Locarnini, R.A., Garcia, H.E., Mishonov, A.V., 2009 Global ocean heat content 1955-2008 in light of recently revealed instrumentation problems. Geophys. Res. Lett. 36.

Lindo-Atichati, D., Bringas, F., Goni, G., 2013. Loop current excursions and ring detachments during 1993-2009. Int. J. Remote Sens. 34 (14), 5042-5053.

Locarnini, R.A., Mishonov, AV., Antonov, J.I., Boyer, T.P., Garcla, H.E., Baranova, O.K. Zweng, M.M., Johnson, D.R., 2010. World Ocean Atlas 2009, Volume 1: Temperature, Washington, DC. In: US Government Printing Office, NOAA Atlas NESDIS $68,184 \mathrm{p}$.

Lohmann, G.P., 1995. A model for variation in the chemistry of planktonic-foraminifera due to seco 455 .

Lohmantn, G.P., Schweitzer, P.N., 1990. Globorotalia truncatulinoides' GROWTH AND CHEMISTRY AS PROBES OF THE PAST THERMOCLINE: 1 . SHEIL SIZE. Paleoceanography 5 (1), 55-75.

Loncaric, N., Peeters, F.J.C., Kroon, D., Brum recent planktic foraminifera at the central Walvis ridge (SE Atlantic). Paleoceanography 21 (3)

Marchitto, T.M., 2006. Precise multielemental ratios in cmall foramniferal samples determined by sector field ICP-MS. Geochem. Geophys. Geosyst. 7, 005P13, httor://dx. 


\section{ARTICLE IN PRESS}

C.E. Reynolds et al

dof.org/10.1029/2005GC001018

Matsumoto, K., Lynch-Stieglitz, J., 2003. Persistence of gulf stream separation during the last glacial period: implications for current separation theories. Journal of geophyical Resear

McKenna, V.S., Prell, W.L., 2004. Calibration of the Mg/Ca of Globorotalia truncatulinoides (R) for the reconstruction of marine temperature gradients. Paleoceanography 19 (2).

Mortyn, P.G., Charles, C.D., 2003. Planktonic Foraminiferal Depth Habitat and Delta O-18 Calibrations: Plankton Tow Results from the Atlantic Sector of the Southern Ocean: Paleoceanography. Vol. 18 no. 2 .

Mulitza, S., Donner, B., Fischer, G., Paul, A., Pätzold, J., Rühlemann, C., Segl, M., 2004. The South Atlantic oxygen isotope record of planktic foraminifera. In: Wefer, G., Mulitza, S., Ratmeyer, V. (Eds.), The South Atlantic in the Late Quatemary. Reconstruction of Material Budgets and Current Systems. Springer-Verlag, Berlin, pp. $121-142$

Mulitza, S., Dürkoop, A., Hale, W., Wefer, G., Niebler, H.S., 1997. Platlktonic foraminifera as recorders of past surface-water stratification. Geology 25 (4), 335-338.

Mulitza, S., Boltovskoy, D., Dotiner, B., Meggers, H., Paul, A., Wefer, G., 2003. Temperature: delta O-18 relationships of planktonic foraminifera collected from surface waters. Palaeogeogr. Palaeoclimatol. Palaeoecol. 202 (1-2), 143-152.

ONeil, J.R., Clayton, R.N., Mayeda, T.K., 1969. Oxygen isotope fractionation in divalent metal carbonates. J. Chem. Phys. 51, 5547-5558.

Paton, C., Hellstrom, J., Paul, B., Woodhead, J., Hergt, J., 2011. Iolite: freeware for the visualization and processing of mass spectrometric data. Joumal of Analytical Atomic Spectometry 26 (12), 2508. http://dx.dol.org/10.1039/c1ja10172b.

Poore, R.Z., Tedesco, K.A., Spear, J.W., 2013. Seasonal flux and assemblage composition of Planktic foraminifers from a sediment-trap study in the northem Gulf of Mexico. J. Coast. Res. 6-19.

Ravelo, A.C., Fairbanks, R.G., 1992. Oxygen isotopic composition of multiple species of planktonic foraminifera: recorders of the modern photic zone temperature gradient. Paleoceanography 7 (6), 815-831.

Rayner, N.A., Parker, D.E., Horton, E.B., Folland, C.K., Alexander, L.V., Rowell, D.P., Kent, E.C., Kaplan, A., 2003. Global analyses of sea surface temperature, sea ice, and night marine air temperature since the late nineteenth century. Journal of Geophysical Research-Atmospheres 108 (D14).

Rebotim, A., Voelker, A.H.L., Jonkers, L., Wantiek, J.J., Meggers, H., Schiebel, R., Fraile I., Schultz, M., Kucera, M., 2016. Factors controlling the depth habitat of planktonic foraminifera in the subtropical eastem. North Atlantic: Biogeosciences 14 (4), $824-859$

Regenberg, M., Steph, S., Nürnberg, D., Tiedemann, R., Garbe-Schönberg, D., 2009 Calibrating $\mathrm{Mg} / \mathrm{Ca}$ ratios of multiple planktonic foraminiferal species with delta $\mathrm{O}$ 18-calcification temperatures: Paleothermometry for the upper water column. Earth Planet. Sci. Lett. 278 (3-4), 324-336.

Renaud, S., Schmidt, D.N., 2003. Habitat tracking as a response of the planktic foraminifer Globorotalia truncatulinoides to environmental fluctuations during the last 140 kyr. Mar. Micropaleontol. 49 (1-2), 97-122.

Reynolds, C.E., Richey, J.N., 2016. Seasonal flux and assemblage composistion of planktic foraminfera from the northern Gulf of Mexico. In: 2008-2014: U.S. Geological Survey Opent Flle Report. 2016-1115. pp. 14.

Reynolds, C.E., Richey, J.N., Fehrenbacher, J.S., Rosenheim, B.E., Spero, H.J., 2018. Globorotalia Truncatulinoides Sediment Trap Data in the Gulf of Mexico: U.S. Geological Survey Data Release. http://dx.doi.org/10.5066/F72806W4.

Richey, J.N., Tiemey, J.E., 2016. GDGT and alkenone flux in the northern Guif of Mexico: implications for the TEX86 and U-37(K ) paleothermometers. Paleoceatiography 31 (12), 1547-1561.

Richey, J.N., Poore, R.Z, Flower, B.P., Quinn, T., 2007. 1400 yr multiproxy record of climate variability from the northern Gulf of Mexico. Geology 35 (5), 423-426.

Richey, J.N., Hollander, D.J., Flower, B.P., Eglinton, T.I., 2011. Merging late Holocene molecular organic and foraminiferal-based geochemical records of SST in the Gulf of Mexico. Paleoceanography. http://dx.dol.org/10.1029/2010PA002000.

Rongstad, B.L, Marchitto, T.M., Herguera, J.C., 2017. Undersytanding the effects of dissolution on the $\mathrm{Mg} / \mathrm{Ca}$ Paleothermometer in Planktic Foramnifera: evidence from a novel individual Foramnifera Methiod. Paleoceanography 32, 1386-1402. http://
dx.dol.org/10.1002/2017PA003179.

Sadekov, A.Y., Eggins, S.M., De Deckker, P., 2005. Characterization of Mg/Ca distributions in planktonic foraminifera species by electron microprobe mapping. Geochem. Geophys. Geosyst. 6.

Salmon, K.H., Anand, P., Sexton, P.F., Conte, M., 2016. Calcification and growth processes in planktonic foraminifera complicate the use of $\mathrm{B} / \mathrm{Ca}$ and $\mathrm{U} / \mathrm{Ca}$ as carbonate chemistry proxies. Earth Planet. Sci. Lett. 449, 372-381. http://dx.doi.org/10.1016/ j.epsl.2016.05.016.

schiebal, R., Hemleben, C., 2005. Modern planktic foraminifera. Paläontol. Z. 79 (1), 135-148.

Schmidt, D.N., Renaud, S., Bollmann, J., 2003. Response of Planktic Foraminiferal Size to Late Quaternary Climate Change: Paleoceanography. Vol. 18 no. 2.

Schmidt, M.W., Vautravers, M.J., Spero, H.J., 2006. Western Caribbean sea surface temperatures during the late Quaternary. Geochem. Geophys. Geosys. 7. http://dx. dol.org/10.1029/2005GC000957.

Schmuker, B., Schiebel, R., 2002. Planktic foraminifers and hydrography of the eastem and northem Caribbean Sea. Mar. Micropaleontol. 46 (3-4), 387-403.

Shackleton, N.J., 1974. Attainment of isotopic equilibrium between ocean water and the benthonic foraminifera genus Uvigerina: isotopic changes in the ocean duritig the last glacial 219, 203-209.

Spear, J.W., Poore, R.Z., Quinn, T.M., 2011. Globorotalia truncatulinoides (dextral) Mg/ $\mathrm{Ca}$ as a proxy for Gulf of Mexico winter mixed-layer temperature: evidence from a sediment trap in the northern Gulf of Mexico. Mar. Micropaleontol. 80 (3-4), 53-61.

Spero, H.J., Mielke, K.M., Kalve, E.M., Lea, D.W., Pak, D.K., 2003. Multispecies approach to reconstructing eastern equatorial Pacific themocline hydrography during the past 360 kyr. Paleoceanography 18 (1).

Steinhardt, J., de Nooijer, L.L.J., Brummer, G.J., Reichart, G.J., 2015. Profiling planktonic foraminiferal crust formation. Geochem. Geophys. Geosyst. 16 (7), 2409-2430.

Steph, S., Regenberg, M., Tiedemann, R., Mulitza, S., Nürnberg, D., 2009. Stable isotopes of planktonic foraminifera from tropical Atlantic/Caribbean core-tops: implications for reconstructing upper ocean stratification. Mar. Micropaleontol. 71 (1-2), 1-19.

Thirumalai, K., Quinn, T.M., Marino, G., 2016. Constraining past seawater $8^{18} \mathrm{O}$ and temperature records developed from foraminiferal geochemistry. Paleoceanography 31, 1409-1422. http://dx.doi.org/10.1002/2016PA002970.

Tolderlund, D.S., Be, A.W.H., 1971. Seasonal distrubution of planktonic foraminifera in the western North Atlantic. Micropaleontology 17 (3), 297-329.

Ujiie, Y., de Garidel-Thoron, T., Watanabe, S., Wiebe, P., de Vargas, C., 2010. Coiling dimorphism within a genetic type of the planktonic foraminifer Globorotalia truncatulinoides. Mar. Micropaleontol. 77 (3-4), 145-153.

Vetter, L, Spero, H.J., Russell, A.D., Fehrenbacher, J.S., 2013. LA-ICP-MS depth profiling perspective on cleaning protocols for elemental analyses in planktic foraminifers. Geochem. Geophys. Geosyst. 14 (8), 2916-2931.

Vetter, L., Spero, H.J., Eggins, S.M., Williams, C., Flower, B.P., 2017. Oxygen isotope geochemistry of Laurentide ice-sheet meltwater across termination I. Quatemary Science Review 178, 102-117.

Vukovich, F.M., 1988. Loop current boundary variations. J. Geophys. Res.-Oceans 93 (C12), 15585.

Walker, N.D.N.D., Filley, C.T.C.T., Raghumathan, V.V.V.V., D'Sa, E.J.E.J., Leben, R.R.R.R., Hoffmann, N.G.N.G., Brickley, P.J.P.J., Coholan, P.D.P.D., Sharma, N.N., Graber, H.C.H.C., Turner, R.E.R.E., 2011. Impacts of Loop current frontal cyclonic eddies and wind forcing on the 2010 Gulf of Mexico Oil Spill. In: Liu, Y., Macfadyen, A., Ji, Z.-G., Weisberg, R.H. (Eds.), Monitoring and Modeling the Deepwater Horizon Oil Spill: A Record-Breaking Enterprise. American Geophysical Union, Washington, D. C. httn: / dx.doi.org/10.1029/2011GM001120.

Wilke, I., Meggers, H., Bickertc, T., 2009. Depth habitats and seasonal distributions of recent planktic foraminifers in the Canary Islands region ( 29 degrees $N$ ) based on oxygen isotopes. Deep-Sea Research Part I-Oceanographic Research Papers 56 (1) 89-106.

Williams, D.F., Ehrlich, R., Spero, H.J., Healywilliams, N., Gary, A.C., 1988. Shape and isotopic differences between conspecific foraminiferal Morphotypes and resolution of Paleoceanographic events. Palaeogeogr. Palaeoclimatol. Palaeoecol 64 (3-4), $153-162$ 
APPENDIX B: ENVIRONMENTAL CONTROLS ON THE GEOCHEMISTRY OF

GLOBOROTALIA TRUNCATULINOIDES IN THE GULF OF MEXICO: IMPLICATIONS FOR PALEOCEANOGRAPHIC RECONSTRUCTIONS SUPPLEMENTAL 


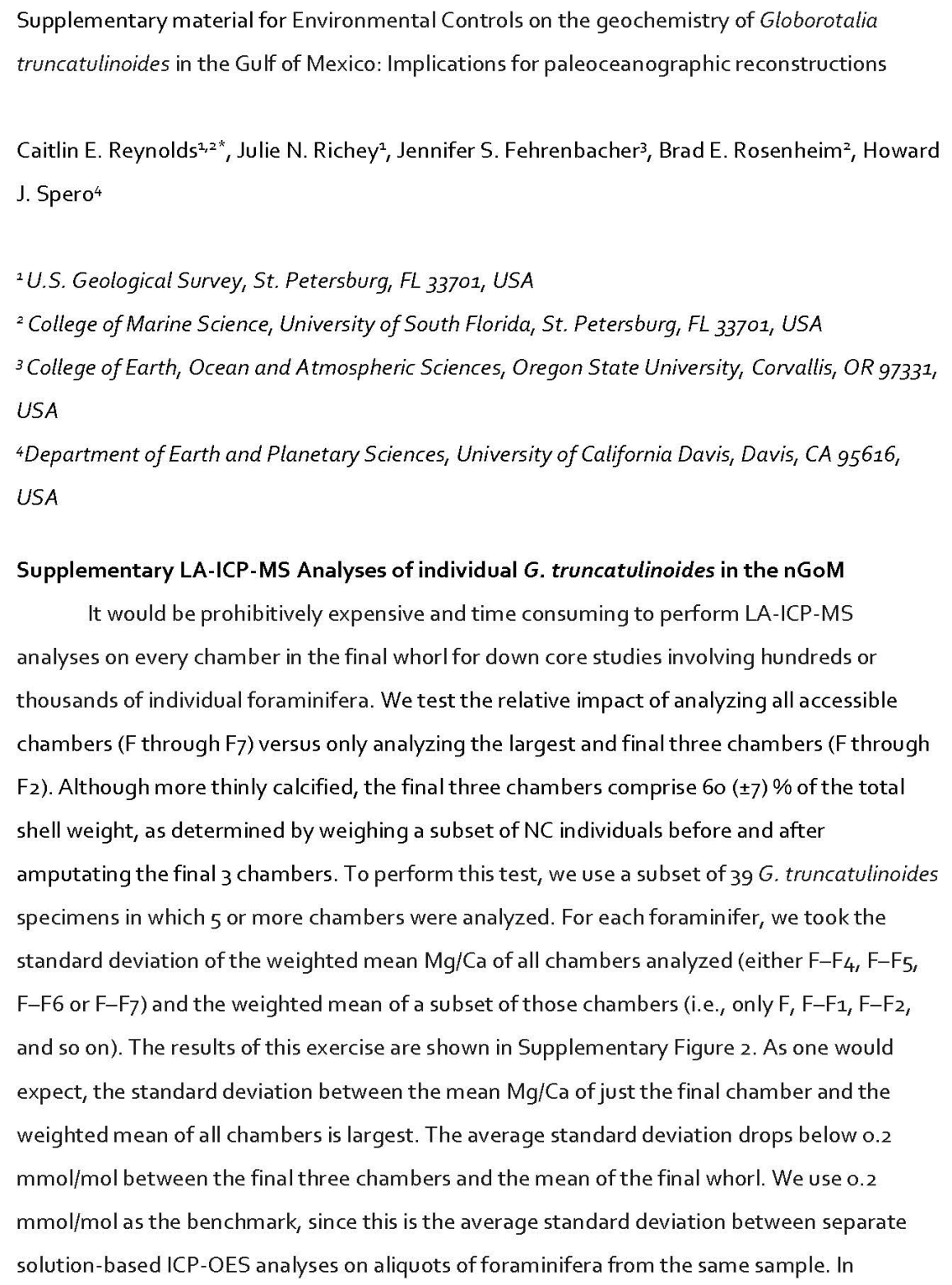


summary, the more chambers you analyze, the closer you get to a value representative of the bulk shell $\mathrm{Mg} / \mathrm{Ca}$. However, the weighted mean of the final three chambers results in an acceptable level of precision.

\section{Supplementary description of homogenous zone in encrusted G. truncatulinoides}

Due to the extremely thick test wall of encrusted individuals, different laser parameters were used to analyze C versus NC (i.e., longer dwell time and faster repetition rate), so the inner test wall (representing the non-encrusted ontogenetic stage) is not well represented in the $\mathrm{Mg} / \mathrm{Ca}$ profiles of the encrusted individuals. This makes it difficult to identify the lamellar calcite in the LA-ICP-MS data of encrusted G. truncatulinoides. However, we determined a method to calculate the relative percentage of lamellar versus secondary calcite in encrusted individuals. We identified the secondary crust in laser ablation profiles and compared the ablation time of that to the lamellar calcite on the inner part of the shell. The crust is generally homogenous and much lower in $\mathrm{Mg} / \mathrm{Ca}$ and $\mathrm{Ba} / \mathrm{Ca}$ than the lamellar calcite. We identified the homogenous zone as seen in Figure $\mathrm{S}_{4}$ for one spot on every chamber $\left(\mathrm{F}-\mathrm{F}_{4}\right)$ of each encrusted individual. We identified the boundary between the crust and the lamellar calcite by identifying the point at which $\mathrm{Mg} / \mathrm{Ca}$ values were higher than two standard deviations from the mean $\mathrm{Mg} / \mathrm{Ca}$ of the homogenous zone. In a few cases ( $11 \%$ of the individual chambers), there was structure in the $\mathrm{Mg} / \mathrm{Ca}$ of the crust. In those cases, we used the $\mathrm{Ba} / \mathrm{Ca}$ profiles to identify the crust, as $\mathrm{Ba} / \mathrm{Ca}$ is always homogenous and distinctly lower than the lamellar calcite. LA-ICP-MS profiles demonstrate that the outer crust is relatively homogenous with lower weighted mean $\mathrm{Mg} / \mathrm{Ca}(1.37 \pm 0.36 \mathrm{mmol} / \mathrm{mol})$ than the weighted $\mathrm{Mg} / \mathrm{Ca}$ of the whole shell $(1.53 \pm 0.27$ $\mathrm{mmol} / \mathrm{mol}$ ), average values for all encrusted individuals. Further work on the encrustation and complex life cycle of $G$. truncatulinoides needs to be done to explain the heterogeneity within each shell. 
2011 Non-encrusted G. truncatulinoides

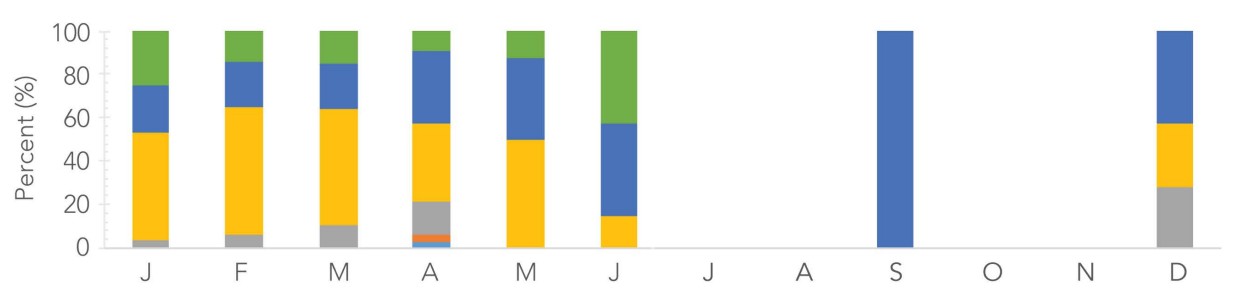

$=>600 \mu \mathrm{m}=500-600 \mu \mathrm{m}=425-500 \mu \mathrm{m}=300-425 \mu \mathrm{m}=212-300 \mu \mathrm{m}=150-212 \mu \mathrm{m}$

2011 Encrusted G. truncatulinoides

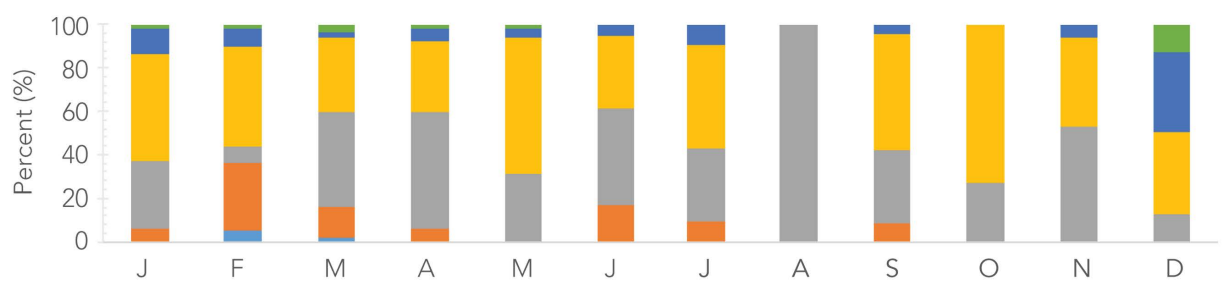

Supplementary Figure 1. Percentage of size fractions for each month in 2011 for non-encrusted (top panel) and encrusted (bottom panel) G. truncatulinoides. The smallest size fraction, at the top of each bar graph, increases with size downwards, 150-212 $\mu \mathrm{m}$ (green), 212-300 $\mu \mathrm{m}$ (blue), 300-425 $\mu \mathrm{m}$ (yellow), 425-500 $\mu \mathrm{m}$ (grey), $500-600 \mu \mathrm{m}$ (orange), and $>600 \mu \mathrm{m}$ (teal). Note there were zero non-encrusted individuals in July, August, October, and November. 
Number of chambers analyzed

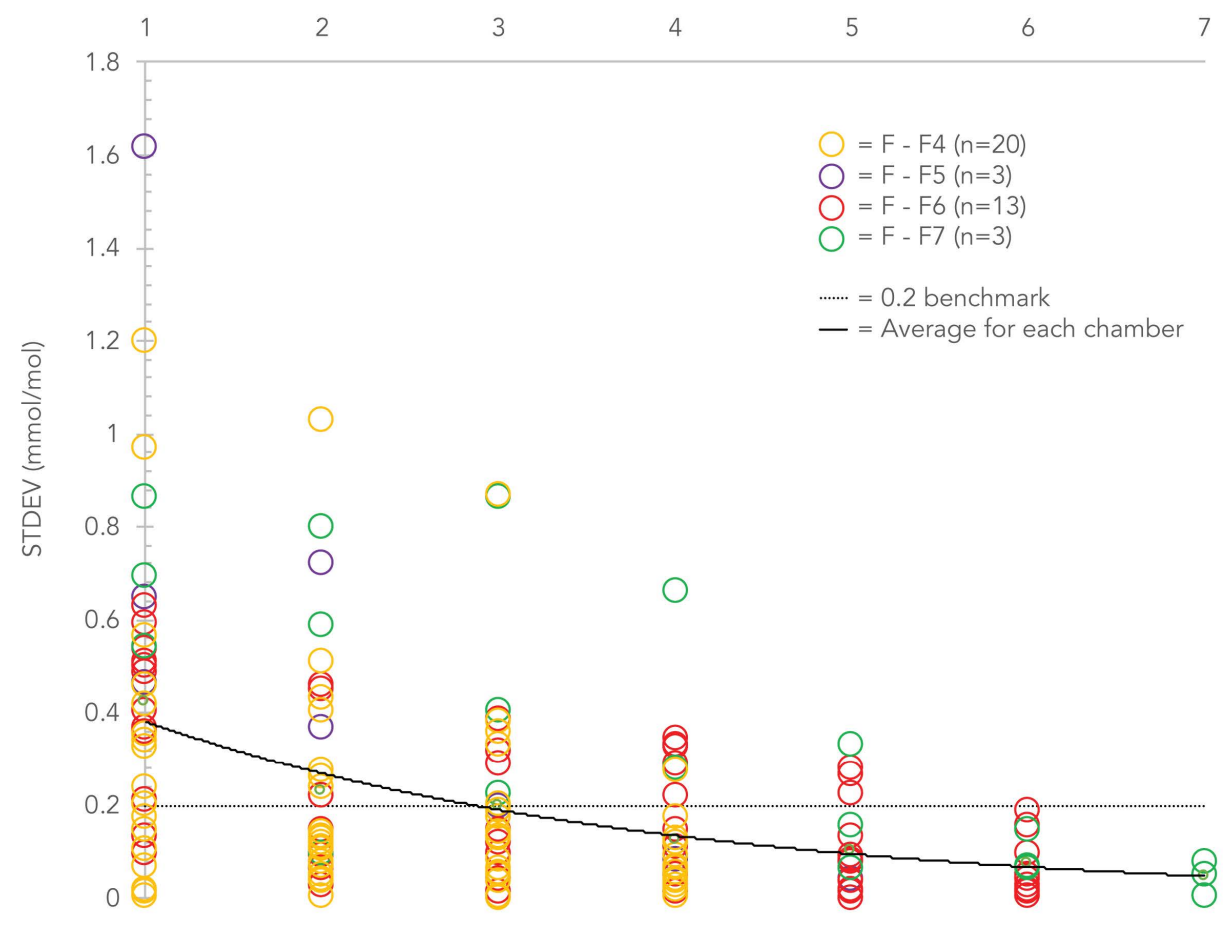

Supplementary Figure 2. Standard deviation (STDEV) from the total weighted Mg/Ca of the entire shell to the weighted $\mathrm{Mg} / \mathrm{Ca}$ from various chambers analyzed on thirty-nine non-encrusted $\mathrm{G}$. truncatulinoides. Data from individuals ablated on 5 to 8 chambers (F-F4 (yellow), F-F5 (purple), F-F6 (red), F-F7 (green). The black line represents the average STDEV for each number of chambers analyzed. The dashed line, 0.2 is the benchmark of error used in solution based measurements. Our data are more precise when the average falls below the benchmark. When at least the final 3 chambers are analyzed, F, F1, and F2, the average STDEV $\leq 0.2$ from the total weighted $\mathrm{Mg} / \mathrm{Ca}$ of the entire shell. 
A.

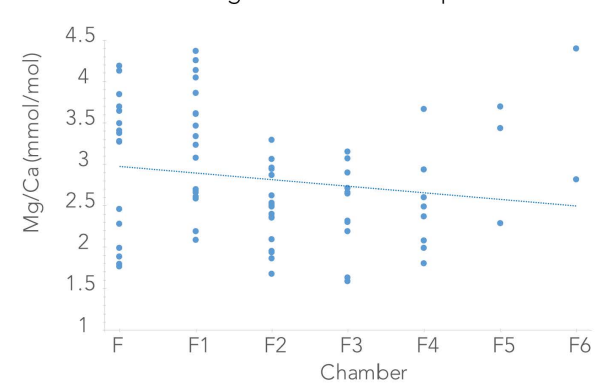

c.

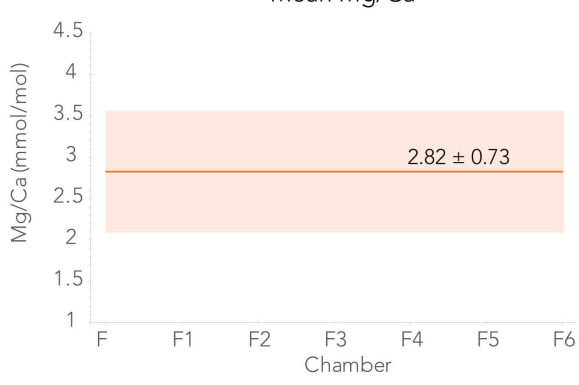

B.

Ablation time and trendline per chamber

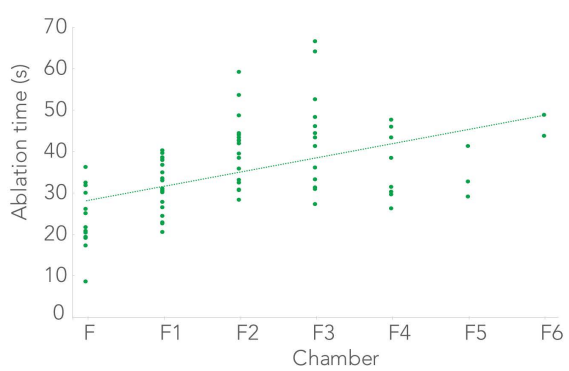

D.

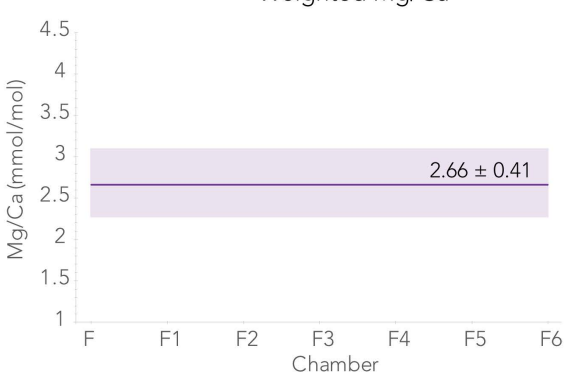

Supplementary Figure 3. (A) All February non-encrusted G. truncatulinoides individual $\mathrm{Mg} / \mathrm{Ca}(\mathrm{mmol} / \mathrm{mol})$ measurements per chamber (blue circles) (trendline is blue dashed line). (B). The ablation time (s) per chamber measurements (green circles) and trendline (green dashed line). (C) The orange line represents the mean Mg/Ca of all chambers and individuals $2.82 \pm 0.73 \mathrm{mmol} / \mathrm{mol}$ (error is the orange shaded region). (D) The purple line is the mean weighted $\mathrm{Mg} / \mathrm{Ca} 2.66 \pm 0.41 \mathrm{mmol} / \mathrm{mol}$ (error shaded in purple region). 
Homogeonous Zone in Encrusted G. truncatulinoides

A.

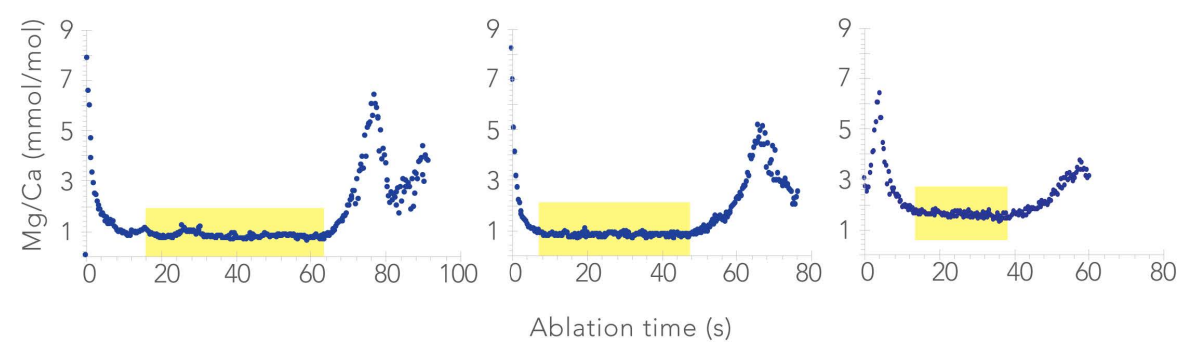

B.

No Homogeonous Zone in Non-Encrusted G. truncatulinoides
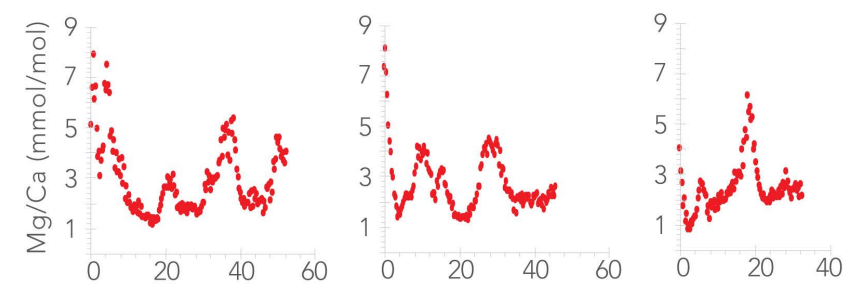

Ablation time (s)

Supplementary Figure 4. Panel A shows the homogenous zone (yellow rectangles) of $\mathrm{Mg} / \mathrm{Ca}$ (blue circles) on three different laser ablation spots from three different encrusted $G$. truncatulinoides individuals. Panel $\mathrm{B}$ shows three different $\mathrm{Mg} / \mathrm{Ca}$ (red circles) laser ablation spots from three different non-encrusted $\mathrm{G}$. truncatulinoides individuals with no evidence of a homogenous zone. 


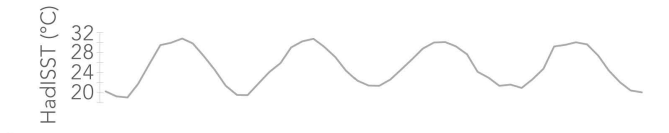

A.

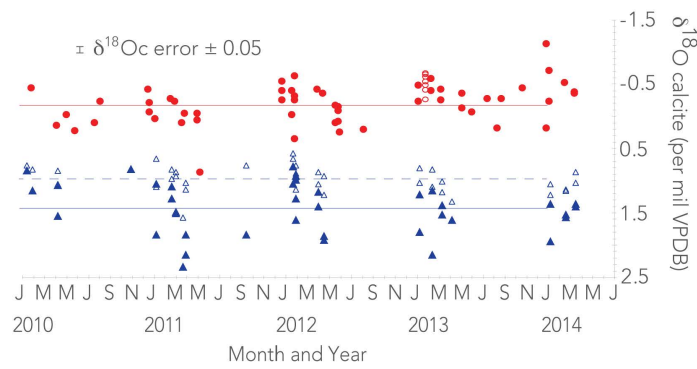

$\begin{array}{ll}\text { - HadISST }\left({ }^{\circ} \mathrm{C}\right) & \Delta C G . \text { truncatulinoides (derived) } \\ \text { - NC Mean (measured) } & \Delta \text { C G. truncatulinoides (measured) } \\ \text { - C Mean (derived) } & \bullet \text { NC G. truncatulinoides (measured) } \\ \text {-. C Mean (measured) } & \circ \text { NC G. truncatulinoides (intra-sample variablity) }\end{array}$

B.

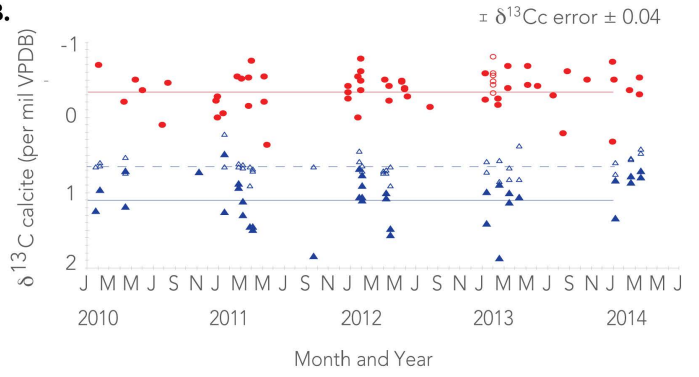

Supplementary Figure 5. Stable isotopes of individual G. truncatulinoides tests. (A.) $\delta^{18} \mathrm{O}_{c}$ and (B.) $\delta^{13} C_{c}$. The blue triangles represent the encrusted $G$. truncatulinoides and the red circles are the non-encrusted form. Analytical precision for isotopic measurements $\pm 0.04 \%$ and $\pm 0.05 \%$ for $\delta^{13} \mathrm{C}_{c}$ and $\delta^{18} \mathrm{O}_{c}$ respectively. The average measured $\delta^{18} \mathrm{O}_{c}$ for non-encrusted $G$. truncatulinoides is $-0.16 \pm 0.32 \%$ and the average measured $\delta^{13} \mathrm{C}_{c}$ is $-0.34 \pm 0.24 \%$ (closed red circles). The average measured $\delta^{18} \mathrm{O}_{c}$ for encrusted individuals is $0.97 \pm 0.20 \%$ and $0.65 \pm 0.14 \%$ for $\delta^{13} \mathrm{C}_{c}$ (open blue triangles). The average derived $\delta^{18} \mathrm{O}_{c}$ and $\delta^{13} \mathrm{C}_{\mathrm{c}}$ for encrusted assuming 29\% lamellar calcite and $71 \%$ secondary calcite is $1.45 \pm 0.40 \%$ and $1.09 \pm 0.32 \%$., respectively. HADiSST is plotted for reference. The open red circles indicate a 1-week sample cup from which 7 individuals were analyzed to assess intra-sample variability. 


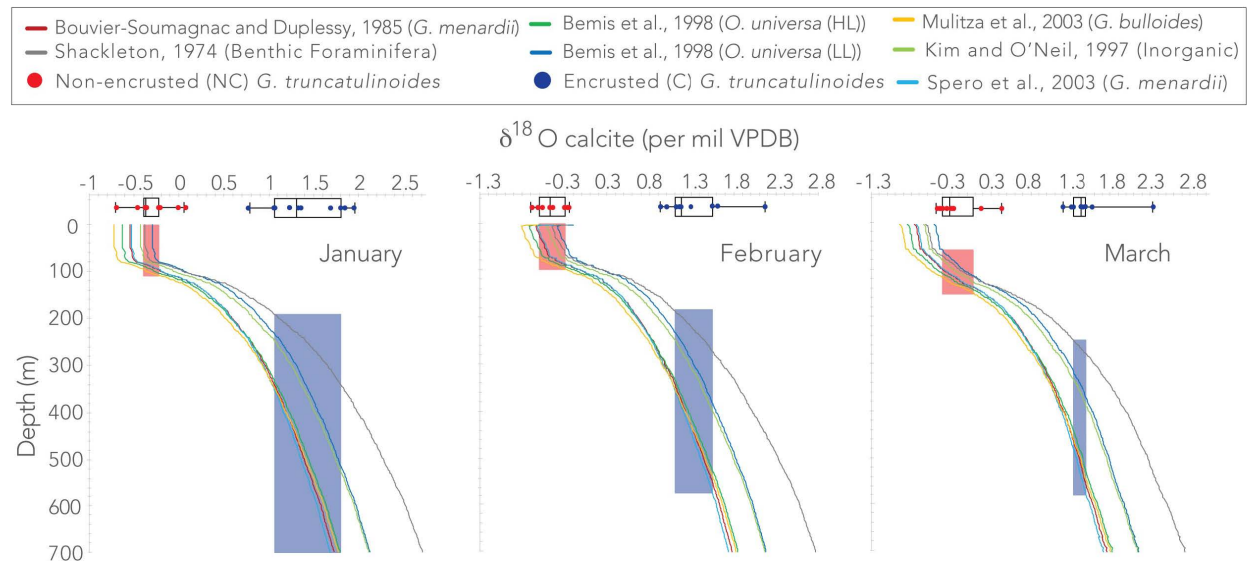

Supplementary Figure 6. April to December calculated $\delta^{18} \mathrm{O}_{c}$ profile comparisons of commonly used calcitetemperature relationship equations: Shackleton1974 (benthic foraminifera) (grey), Kim and O'Neil 1997 (Inorganic) (light green), Bemis et al. 1998 (O. universa HL) (green), Bemis et al. 1998 (O. universa LL) (blue), Mulitza et al. 2003 (G. bulloides) (yellow), Spero et al. 2003 (G. menardi) (light blue), and Bouvier-Soumagnac and Duplessy 1985 (G. menardii) (dark red). Depth habitats of non-encrusted (red rectangles) and encrusted (blue rectangles) $G$. truncatulinoides based on calculated $\delta^{18} \mathrm{O}_{c}$ are indicated. The colored circles (red $=\mathrm{NC}$ and blue $=\mathrm{C}$ ) represent the measured $\delta^{18} \mathrm{O}_{c}$ plotted with the median, IQR, and range for all measurements. Note the scale difference for each month. 


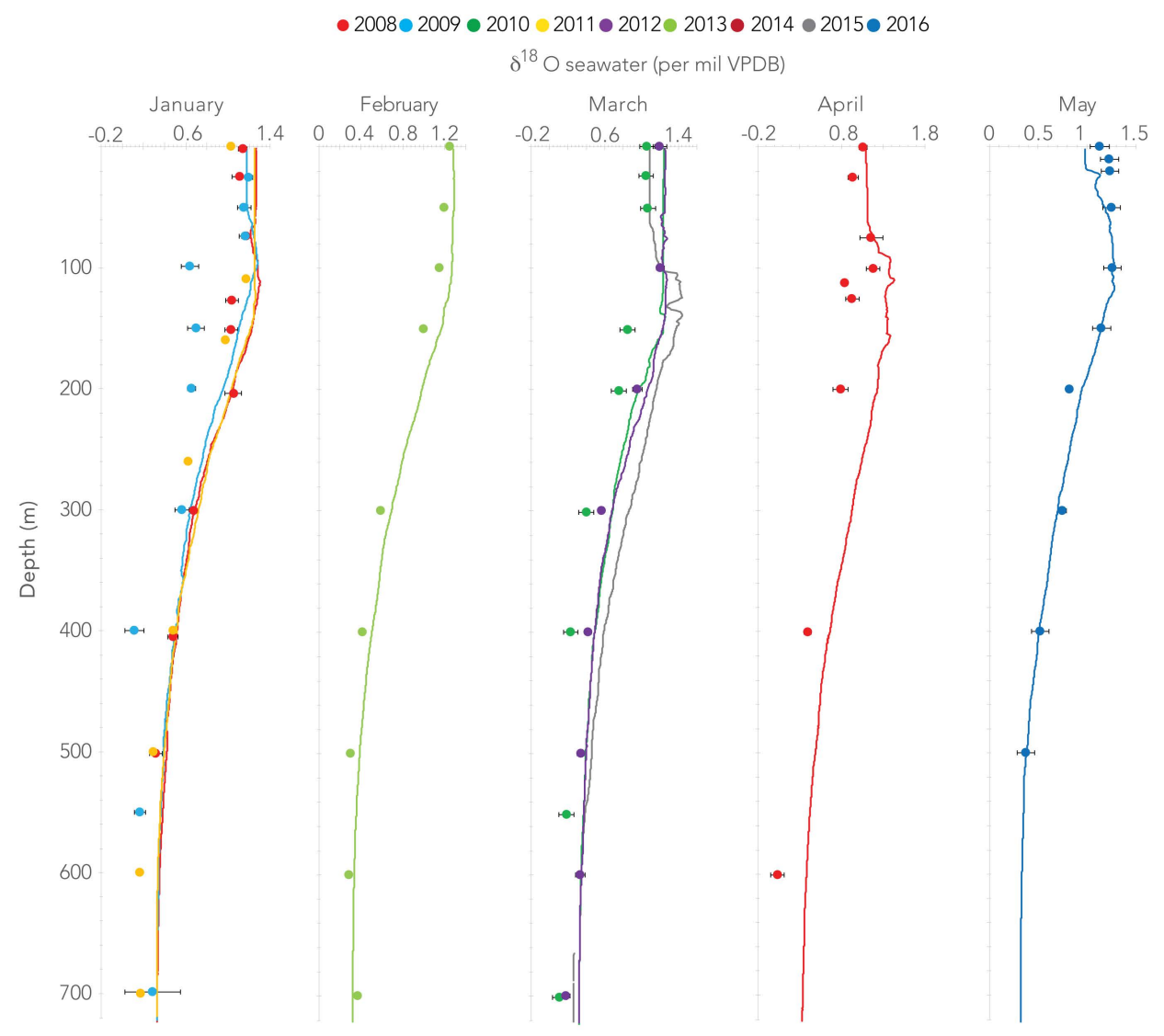

Supplementary Figure 7a. Plotted $\delta^{18} \mathrm{O}_{s w}$ with depth calculated using $\delta^{18} \mathrm{O}_{s w}=(0.59( \pm 0.01) * S)-20.27$ $( \pm 0.30)(r 2=0.76, p>0.00001)$ where $S$ equals in-situ salinity (psu) measurements from CTD casts. The circles indicate measured $\delta^{18} \mathrm{O}_{s w}$ values from the CTD casts. Yearly CTD casts colored 2008 (red), 2009 (light blue), 2010 (green), 2011 (yellow), 2012 (purple), 2013 (light green), 2014 (dark red), 2015 (grey), and 2016 (blue). Error bars on each measurement are indicated. 


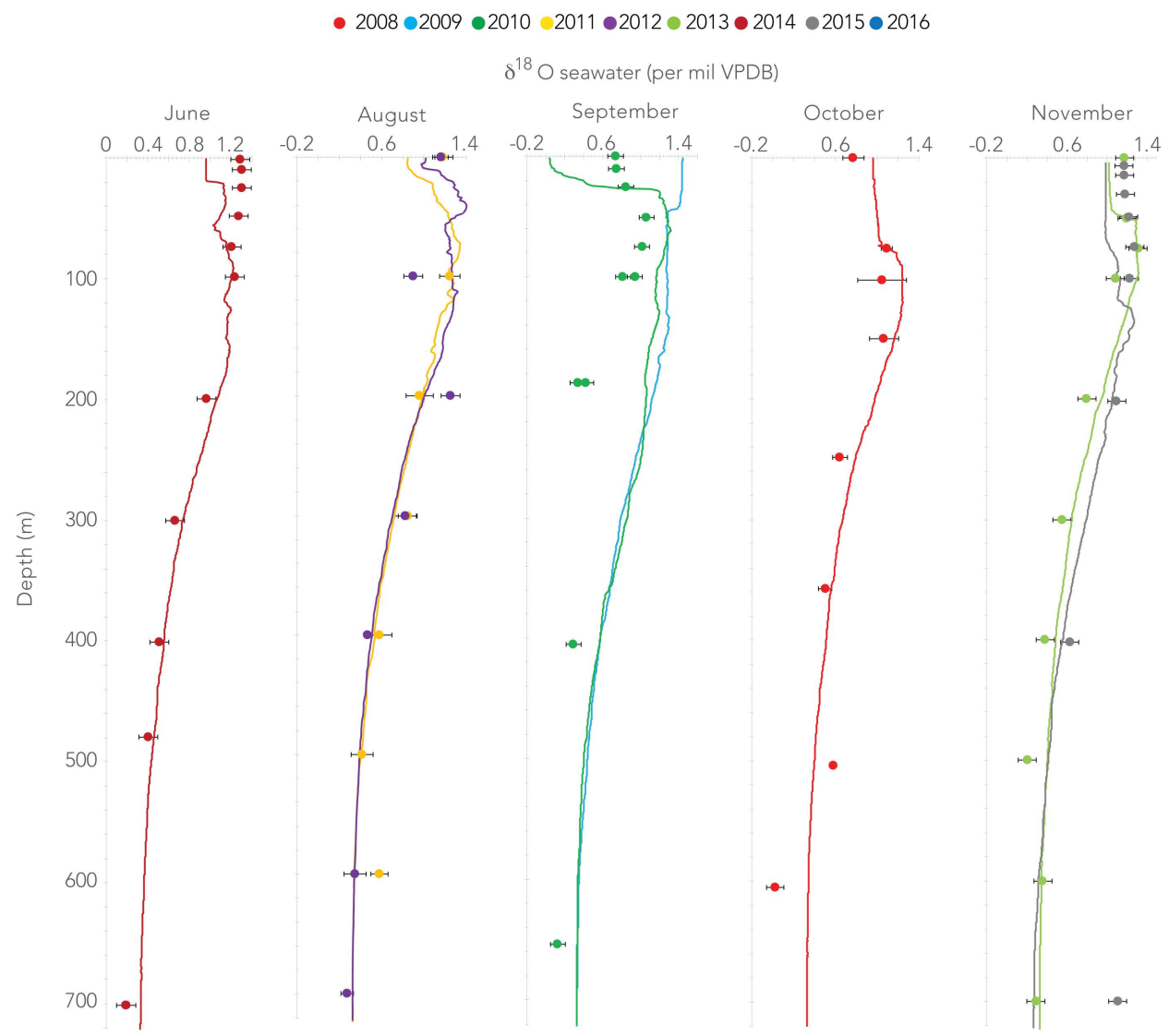

Supplementary Figure 7b. Plotted $\delta^{18} \mathrm{O}_{s w}$ with depth calculated using $\delta^{18} \mathrm{O}_{s w}=(0.59( \pm 0.01) * \mathrm{~S})-20.27$ $( \pm 0.30)(r 2=0.76, p>0.00001)$ where $S$ equals in-situ salinity ( $p s u)$ measurements from CTD casts. The circles indicate measured $\delta^{18} \mathrm{O}_{\text {sw }}$ values from the CTD casts. Yearly CTD casts colored 2008 (red), 2009 (light blue), 2010 (green), 2011 (yellow), 2012 (purple), 2013 (light green), 2014 (dark red), 2015 (grey), and 2016 (blue). Error bars on each measurement are indicated. 


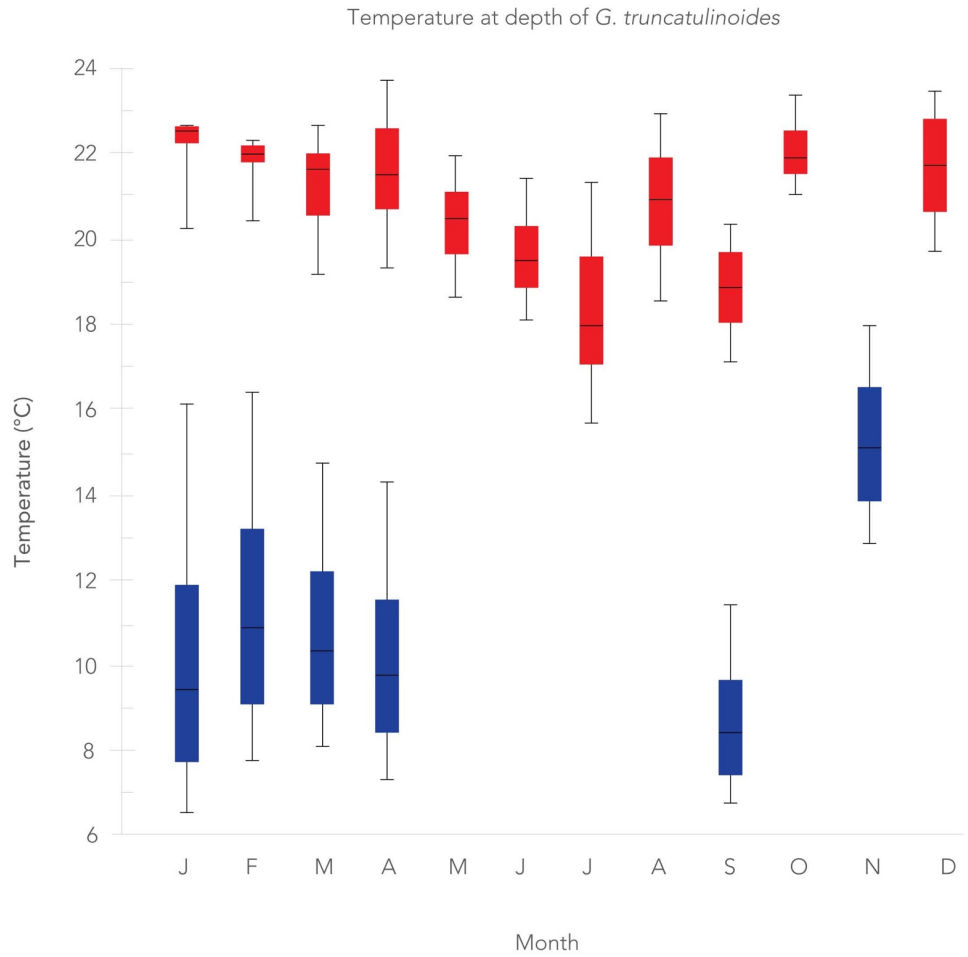

Supplementary Figure 8. Monthly temperature median, IQR, and ranges of non-encrusted (red rectangles) and encrusted (blue rectangles) G. truncatulinoides at designated depth habitats based on averaged CTD profiles in the nGoM. Note there were no $\mathrm{C}$ measurements in May, June, July, August, October, and December and no NC measurements in November. 


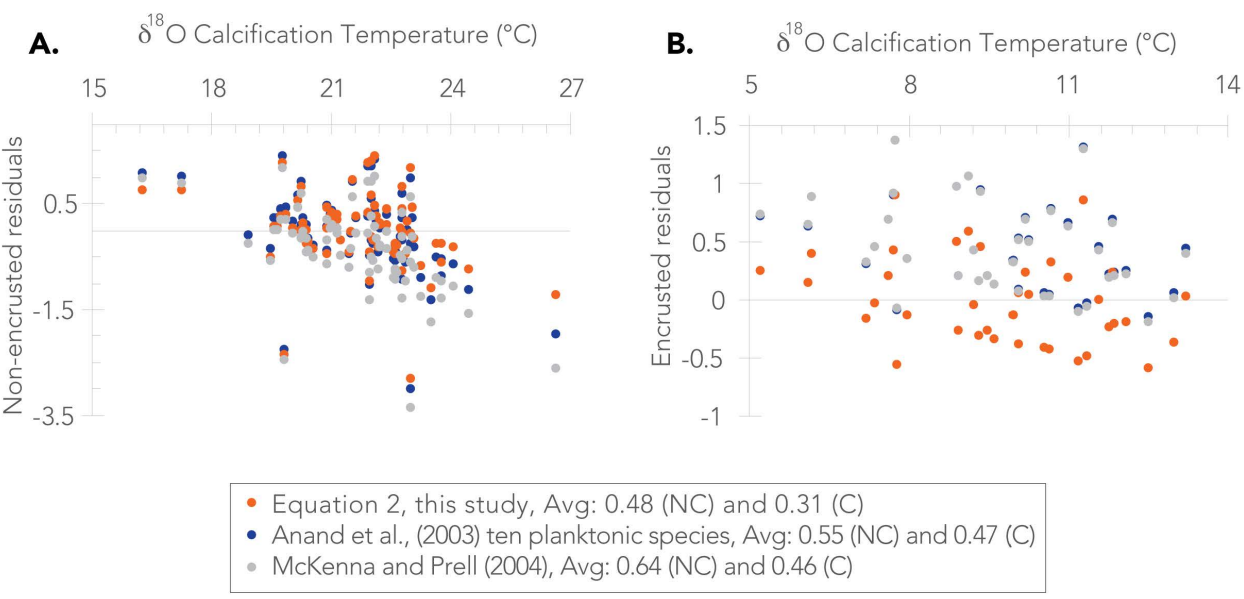

Supplementary Figure 9. $\mathrm{Mg} / \mathrm{Ca}$ residuals plotted against $\delta^{18} \mathrm{O}$ calcification temperature, where residuals $=\mathrm{ABS}$ (measured $\mathrm{Mg} / \mathrm{Ca}$ - predicted $\mathrm{Mg} / \mathrm{Ca}$, of the three best fit exponential equations for non-encrusted (A) and encrusted (B) G. truncatulinoides. Plotted are Anand et al., (2003), ten planktonic species (blue), McKenna and Prell (2004) (grey), and our newly created equation (orange) for both NC and C individuals. 


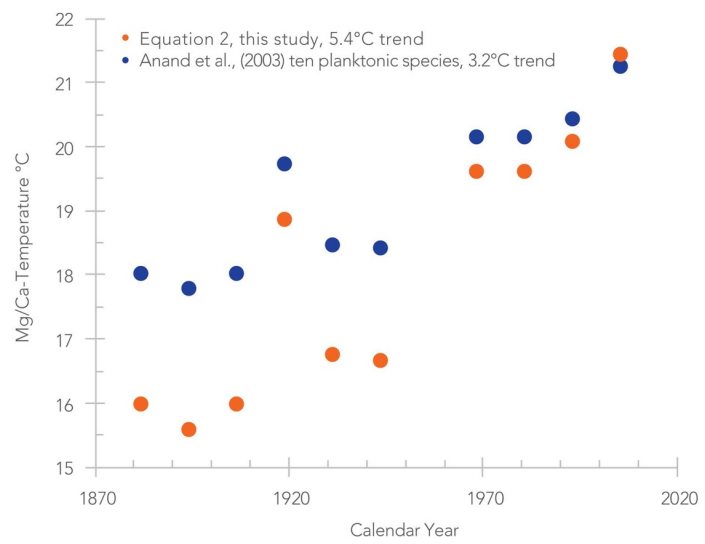

Supplementary Figure 10. Non-encrusted $\mathrm{G}$. truncatulinoides $\mathrm{Mg} / \mathrm{Ca}$ converted to temperature from Pigmy Basin box core (PBBC-1) in the northern GoM (from Spear et al., 2011). Comparison between the Anand et al., (2003), ten planktonic species equation (blue) and Equation 2, this study (orange).

\author{
ICPMS: Ag \\ RF Power $1500 \mathrm{~W}$ \\ Argon (carr 0.95-1.05 1/min (tuned daily) \\ Ar coolant : $151 / \mathrm{min}$ \\ Ar auxiliary $11 / \mathrm{min}$ \\ Dwell time $20 \mathrm{~ms}$ (non-encrusted) $40 \mathrm{~ms}$ (enc

\begin{tabular}{l}
\hline Laser-ablation system L \\
\hline Energy der $1-4.5 \mathrm{~J} / \mathrm{cm}^{2}$ (variable) \\
He gas flon $1.051 / \mathrm{min}$ \\
Laser repet $6 \mathrm{~Hz}$ (non-encrusted) $8 \mathrm{~Hz}$ (encrust \\
Laser spot $\leqslant 44 \mu \mathrm{m}(30 \mu \mathrm{m}$ when needed) \\
$\mathrm{ThO}^{+} / \mathrm{Th}^{+}<0.5 \%$ \\
$\mathrm{U}^{+} / \mathrm{Th}^{+} \quad \sim 1$
\end{tabular}

Supplementary Table 1. Summary of operating conditions for the LA-ICP-MS. 


\section{APPENDIX C: CHAPTER ONE TABLES}

\section{TABLE C.1. NON-ENCRUSTED AND ENCRUSTED DEPTH RANGES AND AVERAGES}

\begin{tabular}{|c|c|c|c|c|c|c|c|c|c|}
\hline \multirow[b]{2}{*}{ Month } & \multirow[b]{2}{*}{$\%$ Flux } & \multicolumn{4}{|c|}{ Nonencrusted Depth Range } & \multicolumn{4}{|c|}{ |Encrusted Depth Range } \\
\hline & & Low & High & Avergae & Weighted Value & Low & High & Average & Weighted Value \\
\hline January & $20.5 \%$ & 0 & 110 & 55 & 11 & 190 & 700 & 445 & 91 \\
\hline Febraury & $53.8 \%$ & 0 & 100 & 50 & 27 & 180 & 570 & 375 & 202 \\
\hline March & $13.2 \%$ & 60 & 150 & 105 & 14 & 245 & 575 & 410 & 54 \\
\hline April & $6.2 \%$ & 90 & 170 & 130 & 8 & 320 & 700 & 510 & 32 \\
\hline May & $1.3 \%$ & 50 & 110 & 80 & 1 & & & & \\
\hline June & $0.4 \%$ & 80 & 160 & 120 & 0 & & & & \\
\hline July & $0.1 \%$ & 60 & 130 & 95 & 0 & & & & \\
\hline August & $0.4 \%$ & 80 & 130 & 105 & 0 & & & & \\
\hline September & $0.0 \%$ & 110 & 170 & 140 & 0 & 385 & 700 & 543 & 0 \\
\hline October & $0.0 \%$ & 80 & 90 & 85 & 0 & & & & \\
\hline November & $0.0 \%$ & & & & & 170 & 320 & 245 & 0 \\
\hline December & $4.1 \%$ & 60 & 120 & 90 & 4 & & & & \\
\hline & & & ated & $\begin{array}{l}\text { epth }(\mathrm{m}) \\
\text { STDEV }\end{array}$ & $\begin{array}{c}66 \\
9\end{array}$ & & ited & $\begin{array}{l}\text { epth }(\mathrm{m}) \\
\text { STDEV }\end{array}$ & $\begin{array}{c}379 \\
76\end{array}$ \\
\hline
\end{tabular}


TABLE C.2 ENCRUSTED HOMOGENOUS ZONE MG/CA DETERMINATIONS

\begin{tabular}{|c|c|c|c|c|c|c|c|c|c|c|c|c|c|c|c|c|c|c|c|}
\hline \multirow[b]{2}{*}{ SAMPLE } & \multirow[b]{2}{*}{ DATE } & \multirow[b]{2}{*}{$\begin{array}{c}\text { Woighted } \mathrm{Mg} / \mathrm{Ca} \\
\text { us ing all calcita } \\
(\mathbf{m m o l} / \mathbf{m} \text { ol) }\end{array}$} & \multicolumn{5}{|c|}{ Avor age of all Chambers an al lyed for every individu al } & \multirow[b]{2}{*}{\begin{tabular}{|c} 
Total \\
Hom ogen ous \\
zone ablation \\
time from omer
\end{tabular}} & \multicolumn{5}{|l|}{$\begin{array}{l}\text { Woight per } \\
\text { cham ber }\end{array}$} & \multicolumn{5}{|c|}{$\begin{array}{l}\text { Weifhted } \\
\text { Value pest } \\
\text { chamber }\end{array}$} & \multirow[b]{2}{*}{$\begin{array}{c}\text { Weighted } \\
\text { Homogenowes Zon } \\
\mathrm{Mg} / \mathrm{Ca} \text { (mmol/mol }\end{array}$} \\
\hline & & & $\begin{array}{l}\text { Aver ap Hom op on ous } \\
\text { zone ablation time (s) }\end{array}$ & $\begin{array}{c}\text { Aver age } \\
\text { Hom oponous } \\
\text { zone } \mathrm{Mg} / \mathrm{Ca} \\
\text { (mm } \mathrm{d} / \mathrm{l} / \mathrm{mol} \text { ) }\end{array}$ & $\begin{array}{c}\text { Total } \\
\text { ablatition } \\
\text { time (s) }\end{array}$ & $\begin{array}{c}\text { Aver aps } \\
\text { Lamellar } \\
\text { Calcits } \\
\mathrm{Mg} / \mathrm{Ca} \\
\text { Immol/mo }\end{array}$ & $\%$ Crust & & $\mathrm{F}$ & $\mathrm{F}_{1}$ & F2 & F3 & F4 & F & $F_{1}$ & F2 $\quad \mathrm{E}$ & E3 & F4 & \\
\hline GMT6-17C1 & 21 的 -10 & 1.62 & 50 & 1.30 & 58 & 1.77 & $87.97 \%$ & 250 & $15.60 \%$ & $25.60 \%$ & $12.00 \%$ & $24.40 \%$ & $22.40 \%$ & 0.16 & 0.28 & 0.130 & 0.28 & 0.38 & 1.23 \\
\hline GMT6-17.C2 & $21 \tan -10$ & 1.23 & 53 & 1.03 & 82 & 1.82 & $66.56 \%$ & 267 & $17.98 \%$ & $22.47 \%$ & $17.23 \%$ & $22.47 \%$ & $19.85 \%$ & 0.23 & 0.19 & 0.150 & 0.22 & 0.25 & 1.02 \\
\hline GMT\&17C1 & $14 \operatorname{Jan}-11$ & 1.24 & 39 & 0.64 & 75 & 2.14 & $52.07 \%$ & 195 & $13.33 \%$ & $21.03 \%$ & $34.87 \%$ & $15.38 \%$ & $15.38 \%$ & 0.09 & 0.10 & 0.300 & 0.07 & 0.11 & 0.67 \\
\hline GMT\&17C2 & $14 \operatorname{Jan}-11$ & 1.55 & 27 & 1.28 & 38 & 2.56 & $72.10 \%$ & 107 & $35.51 \%$ & $20.56 \%$ & $21.50 \%$ & $22.43 \%$ & $0.00 \%$ & 0.60 & 0.30 & 0.210 & 0.22 & 0.00 & 1.33 \\
\hline GMT10-19C1 & $25 \cdot \operatorname{an}-12$ & 1.86 & 59 & 1.72 & 76 & 2.50 & $77.39 \%$ & 236 & $20.34 \%$ & $25.42 \%$ & $23.73 \%$ & $30.51 \%$ & $0.00 \%$ & 0.43 & 0.42 & 0.390 & 0.44 & 0.00 & 1.69 \\
\hline GMT10-19C2 & $25 \cdot \tan -12$ & 1.69 & 43 & 1.84 & 66 & 1.87 & $69.40 \%$ & 213 & $10.33 \%$ & $15.02 \%$ & $26.76 \%$ & $22.54 \%$ & $25.35 \%$ & 0.26 & 0.22 & 0.340 & 0.39 & 0.57 & 1.78 \\
\hline GMT12-16C 1 & $12 \mathrm{fan}-13$ & 1.40 & 57 & 1.19 & 92 & 2.49 & $62.88 \%$ & 286 & $4.55 \%$ & $18.53 \%$ & $26.92 \%$ & $25.17 \%$ & $24.83 \%$ & 0.07 & 0.20 & 0.290 & 0.27 & 0.29 & 1.12 \\
\hline GMT12-16C2 & $12 \mathrm{fan}-13$ & 1.83 & 36 & 1.76 & 52 & 2.48 & $63.92 \%$ & 179 & $3.35 \%$ & $23.46 \%$ & $26.82 \%$ & $25.70 \%$ & $20.67 \%$ & 0.07 & 0.37 & 0.410 & 0.40 & 0.41 & 1.67 \\
\hline GMT $14.7 . \mathrm{C} 1$ & $7 \tan -14$ & 1.61 & 45 & 1.53 & 58 & 2.78 & $73.93 \%$ & 224 & $4.91 \%$ & $15.63 \%$ & $24.11 \%$ & $27.68 \%$ & $27.68 \%$ & 0.09 & 0.24 & 0.330 & 0.38 & 0.40 & 1.45 \\
\hline GMT $14.7 \mathrm{C} 2$ & $7 \tan -14$ & 1.24 & 38 & 1.21 & 60 & 2.03 & $64.22 \%$ & 192 & $7.29 \%$ & $17.19 \%$ & $27.08 \%$ & $22.92 \%$ & $25.52 \%$ & 0.17 & 0.15 & 0.230 & 0.21 & 0.28 & 1.03 \\
\hline GMT6 $18 \mathrm{C} 2$ & $4 \mathrm{Feb}_{\mathrm{e}-10}$ & 1.29 & 53 & 1.02 & 70 & 3.13 & $76.33 \%$ & 265 & $14.34 \%$ & $19.25 \%$ & $22.64 \%$ & $20.00 \%$ & $23.77 \%$ & 0.17 & 0.19 & 0.200 & 0.20 & 0.26 & 1.01 \\
\hline GMT9-3C 1 & 25Feb-11 & 1.50 & 51 & 1.72 & 68 & 2.16 & $77.85 \%$ & 254 & $8.66 \%$ & $13.39 \%$ & $24.02 \%$ & $25.59 \%$ & $28.35 \%$ & 0.25 & 0.25 & 0.210 & 0.26 & 0.55 & 1.52 \\
\hline GMT9-3C2 & 25Feb-11 & 1.06 & 57 & 1.23 & 71 & 2.02 & $75.68 \%$ & 287 & $3.14 \%$ & $25.09 \%$ & $23.69 \%$ & $28.57 \%$ & $19.51 \%$ & 0.07 & 0.24 & 0.180 & 0.25 & 0.29 & 1.02 \\
\hline GMT1020C 1 & $1 \mathrm{Feb}-12$ & 1.31 & 55 & 1.55 & 62 & 1.70 & $90.33 \%$ & 275 & $7.64 \%$ & $21.09 \%$ & $18.91 \%$ & $26.18 \%$ & $26.18 \%$ & 0.21 & 0.26 & 0.210 & 0.30 & 0.39 & 1.37 \\
\hline GMT10.20C2 & 1 Feb-12 & 1.18 & 70 & 1.05 & 86 & 1.72 & $79.54 \%$ & 278 & $0.00 \%$ & $14.39 \%$ & $28.42 \%$ & $26.98 \%$ & $30.22 \%$ & 0.00 & 0.19 & 0.280 & 0.24 & 0.31 & 1.01 \\
\hline GMT $13.2 \mathrm{C} 1$ & $17 \mathrm{Feb}-13$ & 1.82 & 41 & 1.37 & $\infty$ & 2.34 & $50.16 \%$ & 205 & $3.90 \%$ & $20.49 \%$ & $21.95 \%$ & $30.24 \%$ & $23.41 \%$ & 0.07 & 0.28 & 0.330 & 0.30 & 0.30 & 1.28 \\
\hline GMT $13.2 \mathrm{C} 2$ & $17 \mathrm{Feb}-13$ & 2.01 & 46 & 2.59 & 62 & 2.57 & $76.69 \%$ & 229 & $10.92 \%$ & $14.41 \%$ & $19.65 \%$ & $27.07 \%$ & $27.95 \%$ & 0.46 & 0.39 & 0.380 & 0.45 & 0.66 & 2.35 \\
\hline GMT1 $1413 \mathrm{C} 1$ & 18Feb-14 & 1.82 & 41 & 1.96 & 54 & 2.65 & $72.41 \%$ & 204 & $5.39 \%$ & $19.12 \%$ & $26.47 \%$ & $25.00 \%$ & $24.02 \%$ & 0.15 & 0.35 & 0.410 & 0.41 & 0.49 & 1.81 \\
\hline GMT1 $1413 \mathrm{C} 2$ & 18 Feb-14 & 2.04 & 56 & 1.99 & 73 & 3.08 & $75.79 \%$ & 281 & $7.47 \%$ & $25.27 \%$ & $23.49 \%$ & $21.71 \%$ & $22.06 \%$ & 0.19 & 0.56 & 0.440 & 0.33 & 0.40 & 1.92 \\
\hline GMT $9.4 C 1$ & $7 \mathrm{Mar}-11$ & 1.26 & 59 & 1.08 & 86 & 1.77 & $73.84 \%$ & 295 & $9.15 \%$ & $20.00 \%$ & $22.37 \%$ & $26.78 \%$ & $21.69 \%$ & 0.13 & 0.19 & 0.180. & 0.26 & 0.26 & 1.03 \\
\hline GMT9.4C2 & $7 \mathrm{Mar}-11$ & 1.44 & 55 & 1.12 & 89 & 2.34 & $61.03 \%$ & 276 & $5.43 \%$ & $19.57 \%$ & $24.64 \%$ & $26.09 \%$ & $24.28 \%$ & 0.07 & 0.23 & 0.290 & 0.24 & 0.26 & 1.09 \\
\hline GMT97.C2 & $28 \mathrm{Mar} 11$ & 1.69 & 51 & 1.39 & 74 & 2.84 & $65.97 \%$ & 254 & $7.09 \%$ & $19.69 \%$ & $22.83 \%$ & $26.77 \%$ & $23.62 \%$ & 0.13 & 0.26 & 0.270 & 0.34 & 0.32 & 1.32 \\
\hline GMT11.1C1 & $30 \mathrm{Mar} 12$ & 1.41 & 54 & 1.09 & 75 & 3.21 & $71.58 \%$ & 272 & $7.35 \%$ & $18.38 \%$ & $24.63 \%$ & $26.10 \%$ & $23.53 \%$ & 0.10 & 0.18 & 0.250 & 0.28 & 0.24 & 1.05 \\
\hline GMT11.1C2 & $30 \mathrm{Mar} 12$ & 1.74 & 57 & 1.84 & 76 & 2.47 & $72.81 \%$ & 286 & $6.29 \%$ & $19.58 \%$ & $21.33 \%$ & $25.17 \%$ & $27.62 \%$ & 0.15 & 0.34 & 0.380 & 0.38 & 0.52 & 1.76 \\
\hline GMT $134 . \angle 1$ & $14 \mathrm{Mar} \times 13$ & 1.62 & 54 & 1.51 & 67 & 2.85 & $76.63 \%$ & 270 & $6.67 \%$ & $25.93 \%$ & $11.11 \%$ & $28.15 \%$ & $28.15 \%$ & 0.11 & 0.38 & 0.180 & 0.39 & 0.39 & 1.46 \\
\hline GMT $13.4 \mathrm{C} 2$ & $14 \mathrm{Mar} 13$ & 1.15 & 43 & 1.04 & 57 & 2.13 & $74.78 \%$ & 215 & $6.98 \%$ & $13.49 \%$ & $27.44 \%$ & $28.84 \%$ & $23.26 \%$ & 0.08 & 0.13 & 0.280 & 0.31 & 0.24 & 1.04 \\
\hline GMT14-16C 1 & $16 \operatorname{Mar} 14$ & 1.23 & 56 & 1.05 & 90 & 1.79 & $64.59 \%$ & 280 & $13.57 \%$ & $17.50 \%$ & $21.43 \%$ & $28.21 \%$ & $19.29 \%$ & 0.20 & 0.16 & 0.170 & 0.26 & 0.22 & 1.01 \\
\hline GMT1 $4.16 \mathrm{C} 2$ & $16 \mathrm{Mar}-14$ & 1.66 & 27 & 1.73 & 36 & 1.94 & $78.96 \%$ & 136 & $11.76 \%$ & $22.79 \%$ & $22.06 \%$ & $19.85 \%$ & $23.53 \%$ & 0.32 & 0.39 & 0.330 & 0.21 & 0.40 & 1.64 \\
\hline GMT7 4 C 1 & 17. Apr 10 & 1.47 & 65 & 1.39 & 82 & 2.89 & $74.21 \%$ & 325 & $3.69 \%$ & $24.62 \%$ & $27.69 \%$ & $25.23 \%$ & $18.77 \%$ & 0.06 & 0.29 & 0.320 & 0.26 & 0.36 & 1.30 \\
\hline GMT? $4 \mathrm{C} 2$ & 17. Apr-10 & 1.52 & 61 & 1.31 & 88 & 2.37 & $71.97 \%$ & 307 & $10.75 \%$ & $19.22 \%$ & $23.78 \%$ & $21.17 \%$ & $25.08 \%$ & 0.16 & 0.23 & 0.220 & 0.26 & 0.42 & 1.30 \\
\hline GMT9.8C 1 & 4.Apr-11 & 1.81 & 29 & 1.70 & 52 & 2.40 & $52.18 \%$ & 143 & $5.59 \%$ & $11.19 \%$ & $26.57 \%$ & $27.27 \%$ & $29.37 \%$ & 0.10 & 0.21 & 0.540. & 0.42 & 0.39 & 1.65 \\
\hline GMT9.8C2 & 4.Apr-11 & 1.91 & 49 & 1.56 & 94 & 2.42 & $54.07 \%$ & 244 & $6.15 \%$ & $20.09 \%$ & $25.41 \%$ & $24.59 \%$ & $23.77 \%$ & 0.11 & 0.28 & 0.400 & 0.37 & 0.38 & 1.53 \\
\hline GMT $11.2 \mathrm{C} 1$ & 6.Apr-12 & 1.07 & 66 & 0.96 & 86 & 2.26 & $76.73 \%$ & 328 & $15.85 \%$ & $21.69 \%$ & $21.65 \%$ & $18.90 \%$ & $21.95 \%$ & 0.17 & 0.22 & 0.200 & 0.15 & 0.22 & 0.95 \\
\hline GMT 11.2C2 & $6 . \mathrm{Apr}-12$ & 1.37 & 51 & 1.31 & 69 & 2.27 & $70.90 \%$ & 204 & $6.86 \%$ & $30.89 \%$ & $36.27 \%$ & $0.00 \%$ & $25.98 \%$ & 0.10 & 0.41 & 0.420 & 0.00 & 0.32 & 1.26 \\
\hline GMT $11-4 C 1$ & 20.Apr 12 & 1.51 & 40 & 1.57 & 59 & 2.49 & $73.39 \%$ & 201 & $6.97 \%$ & $18.41 \%$ & $24.38 \%$ & $24.38 \%$ & $25.87 \%$ & 0.17 & 0.24 & 0.290 & 0.33 & 0.40 & 1.44 \\
\hline GMT11.4C2 & 20.Apr 12 & 1.51 & 45 & 1.22 & 75 & 2.52 & $60.29 \%$ & 227 & $7.49 \%$ & $26.87 \%$ & $13.22 \%$ & $25.11 \%$ & $27.31 \%$ & 0.11 & 0.31 & 0.160 & 0.27 & 0.34 & 1.18 \\
\hline GMT $13.6 \mathrm{C} 1$ & 11.Apr.13 & 1.81 & 60 & 1.92 & 73 & 2.83 & $78.91 \%$ & 300 & $5.67 \%$ & $21.33 \%$ & $26.33 \%$ & $26.67 \%$ & $20.00 \%$ & 0.14 & 0.36 & 0.470. & 0.41 & 0.43 & 1.81 \\
\hline GMT 10-3NC1 & $18 \delta_{\mathrm{ep}-11}$ & 1.84 & 53 & 2.20 & $\infty 0$ & 2.35 & $75.45 \%$ & 105 & $45.71 \%$ & $54.29 \%$ & $0.00 \%$ & $0.00 \%$ & $0.00 \%$ & 1.41 & 0.71 & 0.000 & 0.00 & 0.00 & 2.12 \\
\hline GMT 87 NC 1 & 5.Now 2010 & 1.27 & 128 & 1.58 & 137 & 2.17 & $90.07 \%$ & 384 & $11.72 \%$ & $17.19 \%$ & $71.09 \%$ & $0.00 \%$ & $0.00 \%$ & 0.27 & 0.24 & 0.780 & 0.00 & 0.00 & 1.28 \\
\hline
\end{tabular}


TABLE C.3 NON-ENCRUSTED AND ENCRUSTED SAMPLE MORPHOMETRICS, GEOCHEMICAL, ISOTOPIC, AND TEMPERATURE DATA

\begin{tabular}{|c|c|c|c|c|c|c|c|c|c|}
\hline Sample & Date & Length ( $\mu \mathrm{m})$ & Weight (pg) & $\begin{array}{l}\text { Weighted } \mathrm{Mg} / \mathrm{Ca} \\
(\text { mmol/mol })\end{array}$ & $\begin{array}{c}\text { Measured } 5180 \mathrm{C} \\
\text { (per mil VPDB) }\end{array}$ & $\begin{array}{c}\text { Measured } 813 \mathrm{Cc} \\
\text { (per mil VPDB) }\end{array}$ & $\begin{array}{c}\text { Temperature }\left({ }^{\circ} \mathrm{C}\right) \\
\text { Spero et al., } 2003 \\
(G, \text { menar dii })\end{array}$ & $\begin{array}{r}\text { Temperature }\left({ }^{\circ} \mathrm{C}\right) \\
\text { Anand et al, } 2003\end{array}$ & $\begin{array}{c}\text { Temperature }\left({ }^{\circ} \mathrm{C}\right) \\
\text { Equation } 2 \text { (th is study) }\end{array}$ \\
\hline GMT6-17-NC1 & 21- $\tan \cdot 10$ & 220 & 18.4 & 2.80 & 0.37 & 0.74 & 22.75 & 22.19 & 23.04 \\
\hline GMT6-17-NC2 & 21-Jan-10 & 220 & 10.7 & $\mathrm{NaN}$ & $\mathrm{NaN}$ & $\mathrm{NaN}$ & $\mathrm{NaN}$ & $\mathrm{NaN}$ & $\mathrm{NaN}$ \\
\hline GMT8-17.NCl & 14-Jan-11 & 220 & 16.6 & 2.12 & 0.06 & 0.04 & 20.54 & 19.10 & 17.83 \\
\hline GMT8-17-NC2 & 14-Jan-11 & 220 & 17.1 & 2.08 & 0.01 & 0.01 & 20.90 & 18.89 & 17.47 \\
\hline GMT10-19-NC1 & 25 -Jan 12 & 200 & 18.4 & 2.75 & 0.38 & 0.54 & 22.80 & 21.99 & 22.70 \\
\hline GMT10-19-NC2 & 25--an-12 & 240 & 30.2 & 2.18 & 0.47 & 0.22 & 23.26 & 19.41 & 18.35 \\
\hline GMT12-16-NC1 & 12-Jan-13 & 220 & 18.1 & 2.56 & 0.23 & 0.58 & 22.03 & 21.20 & 21.36 \\
\hline GMT12-16-NC2 & 12-Jan-13 & 250 & 21.1 & 2.29 & 0.70 & 0.49 & 24.44 & 19.96 & 19.27 \\
\hline GMT 14.7.NCl & 7.-Jan-14 & 240 & 20.2 & 2.25 & 0.22 & 0.48 & 21.98 & 19.76 & 18.94 \\
\hline 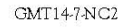 & 7.-Jan-14 & 230 & 21 & 2.01 & 0.38 & 0.41 & 22.80 & 18.51 & 16.83 \\
\hline GMT6-18.NCl & 4 Feb-10 & 200 & 17 & 2.68 & 0.43 & 0.68 & 23.06 & 21.70 & 22.22 \\
\hline GMT6-18.NC2 & 4.Feb-10 & 240 & 21.7 & 3.26 & $\mathrm{NaN}$ & $\mathrm{NaN}$ & $\mathrm{NaN}$ & 23.88 & 25.88 \\
\hline GMT9-3-NC1 & 25-Feb-11 & 260 & 26.9 & 2.81 & 0.27 & 0.53 & 22.21 & 22.23 & 23.10 \\
\hline GMT9-3.NC2 & 25Feb-11 & 230 & 22.2 & 2.49 & 0.24 & 0.76 & 22.06 & 20.89 & 20.84 \\
\hline GMT1C-20-NCl & 1-Feb-12 & 230 & 32.5 & 2.67 & 0.63 & 0.48 & 24.07 & 21.66 & 22.15 \\
\hline GMT10-20-NC2 & 1-Feb-12 & 250 & 28 & 2.33 & 0.57 & 0.15 & 23.78 & 20.15 & 19.59 \\
\hline GMT13-2NCl & $17 \mathrm{Feb} \cdot 13$ & 220 & 23.5 & 2.36 & 0.39 & .0 .24 & 22.87 & 20.29 & 19.83 \\
\hline GMT13.2.NC2 & 17.Feb.13 & 190 & 15.6 & 1.81 & 0.52 & 0.35 & 23.52 & 17.34 & 14.87 \\
\hline GMT14-13-NC1 & 18-Feb-14 & 190 & 12.3 & 3.25 & $\mathrm{NaN}$ & $\mathrm{NaNN}$ & $\mathrm{NaN}$ & 23.85 & 25.83 \\
\hline GMT14-13-NC2 & 18:Fcb-14 & 170 & 9.7 & 2.98 & 0.21 & 0.50 & 21.92 & 22.88 & 24.20 \\
\hline GMTQ $4 \mathrm{NCl}$ & 7.Mrr:11 & 220 & 20.6 & 1.70 & 0.21 & 0.51 & 21.95 & 16.65 & 13.69 \\
\hline GMTS-A-NC2 & 7-Mar:11 & 220 & 22.1 & 2.41 & 0.12 & 0.52 & 20.25 & 20.52 & 20.23 \\
\hline GMT9-7-NC1 & $28 \mathrm{Mar}-11$ & 240 & 22.6 & 2.43 & 0.12 & 0.14 & 20.24 & 20.62 & 20.38 \\
\hline GMTO-7.NC2 & $28 \mathrm{Max}-11$ & 220 & 20.1 & 1.99 & 0.37 & 0.35 & 18.93 & 18.40 & 16.64 \\
\hline GMT11-1.NC1 & $30-\mathrm{Mar} \cdot 12$ & 220 & 24 & 2.82 & 0.30 & 0.61 & 22.39 & 22.27 & 23.17 \\
\hline GMT11-1NC2 & $30-\mathrm{Mar} \cdot 12$ & 210 & 18.8 & $\mathrm{NaN}$ & 0.42 & 0.67 & 22.98 & $\mathrm{NaN}$ & $\mathrm{NaN}$ \\
\hline GMT13.4:NCl & $14 \mathrm{Mar} \cdot 13$ & 240 & 28.7 & 2.94 & 0.25 & 0.37 & 22.14 & 22.73 & 23.95 \\
\hline GMT13-4:NC2 & 14:Mar 13 & 250 & 42.2 & 2.31 & 0.34 & 0.29 & 22.61 & 20.05 & 19.43 \\
\hline OMT14-16-NC1 & $16 \mathrm{Mar}-14$ & 220 & 21 & 3.61 & 0.38 & 0.51 & 22.78 & 25.01 & 27.79 \\
\hline GMT14:16-NC2 & $16 \mathrm{Mar} \cdot 14$ & 240 & 22.7 & 4.08 & 0.24 & 0.28 & 22.10 & 26.37 & 30.09 \\
\hline GMT7-A-NC1 & 17-Apr 10 & 220 & 27.2 & 2.44 & 0.16 & 0.20 & 20.02 & 20.66 & 20.46 \\
\hline GMT7-ANC2 & 17:Apr 10 & 210 & 19.2 & 2.87 & 0.04 & 0.74 & 21.03 & 22.47 & 23.50 \\
\hline GMT9.8NC1 & 4.Apr-11 & 260 & 31.1 & 2.62 & 0.22 & 0.17 & 19.72 & 21.45 & 21.79 \\
\hline GMTS-8.NC2 & 4-Apr-11 1 & 210 & 17.6 & $\mathrm{NaN}$ & $\mathrm{NaN}$ & $\mathrm{NaN}$ & $\mathrm{NaN}$ & $\mathrm{NaN}$ & $\mathrm{NaN}$ \\
\hline GMT11-2NCl & 6-Apr-12 & 220 & 19.1 & 2.75 & 0.42 & 0.48 & 23.01 & 21.99 & 22.70 \\
\hline GMT11-2NC2 & 6Apr-12 & 240 & 18.2 & 2.46 & 0.35 & 0.21 & 22.62 & 20.75 & 20.61 \\
\hline GMT11.4.NCl & 20-Apr:12 & 250 & 30.8 & 2.33 & 0.34 & 0.41 & 22.59 & 20.15 & 19.59 \\
\hline GMT11.4.NC2 & 20 -Apr 12 & 230 & 24.7 & 2.56 & 0.01 & 0.21 & 20.91 & 21.20 & 21.36 \\
\hline GMT13-6NCl & 11.Apr 13 & 240 & 29.1 & $\mathrm{NaN}$ & $\mathrm{NaN}$ & $\mathrm{NaN}$ & $\mathrm{NaN}$ & $\mathrm{NaN}$ & $\mathrm{NaN}$ \\
\hline GMT13-5.NC2 & 11-Apr:13 & 220 & 17.1 & 3.54 & 0.13 & 0.53 & 21.52 & 24.80 & 27.43 \\
\hline GMT78-NC1 & 15 May 10 & 230 & 18.8 & 2.93 & 0.01 & 0.49 & 20.90 & 22.70 & 23.89 \\
\hline GMT78-NC2 & 15 May 10 & 200 & 16.6 & 2.80 & 0.03 & 0.53 & 21.00 & 22.19 & 23.04 \\
\hline GMT9-13.NCl & 9.May -11 & 120 & 13.1 & 2.22 & 0.08 & 0.19 & 20.44 & 19.61 & 18.69 \\
\hline GMT9.13:NC2 & 9-May-11 & 190 & 12.1 & 2.71 & 0.89 & 0.38 & 16.29 & 21.83 & 22.42 \\
\hline GMT9-14-NCl & 16 May 11 & 200 & 19.7 & 3.24 & 0.12 & 0.47 & 20.24 & 23.81 & 25.77 \\
\hline GMT11.9.NCl & 25.May 12 & 180 & 10.7 & 2.89 & 0.15 & 0.46 & 21.62 & 22.54 & 23.63 \\
\hline GMT11-9.NC2 & 25 May 12 & 180 & 12 & 2.17 & 0.12 & 0.42 & 21.47 & 19.36 & 18.26 \\
\hline GMT13-8.NCl & 9-May.13 & 240 & 29.8 & 2.49 & 0.34 & .0 .67 & 22.60 & 20.89 & 20.84 \\
\hline GMT13.8.NC2 & 9.Мay -13 & 250 & 33.9 & 2.46 & 0.35 & 0.35 & 22.65 & 20.75 & 20.61 \\
\hline GMT7-11-NC1 & 6-Jun-10 & 240 & 33.4 & 2.43 & 0.23 & 0.34 & 19.67 & 20.62 & 20.38 \\
\hline GMT7-11:NC2 & 6.Jun-10 & 280 & 45.3 & 2.96 & 0.13 & 0.18 & 20.18 & 22.81 & 24.08 \\
\hline GMT9-17.NCl & 6--Jun-11 & 160 & 18.9 & $\mathrm{NaN}$ & $\mathrm{NaN}$ & $\mathrm{NaN}$ & $\mathrm{NaN}$ & $\mathrm{NaN}$ & $\mathrm{NaN}$ \\
\hline GMT9-17.NC2 & 6-Jun-11 & 200 & 13.9 & 2.57 & 0.13 & 0.37 & 21.52 & 21.24 & 21.43 \\
\hline GMT11-10NC1 & 1-Jun-12 & 150 & 6.5 & 2.20 & 0.09 & 0.36 & 20.39 & 19.51 & 18.52 \\
\hline GMT11-10-NC2 & 1-Jun-12 & 160 & 6.4 & 2.46 & 0.09 & 0.36 & 20.39 & 20.75 & 20.61 \\
\hline GMT11-10-NC3 & 1-Jun-12 & 180 & 9.4 & 2.36 & 0.08 & 0.36 & 21.26 & 20.29 & 19.83 \\
\hline GMT11-10-NC4 & 1-Jun-12 & 190 & 12.2 & 1.81 & 0.27 & 0.26 & 19.47 & 17.34 & 14.87 \\
\hline GMT11-11-NC1 & 8.-Jun-12 & 220 & 22.2 & 2.84 & 0.06 & 0.41 & 21.16 & 22.35 & 23.30 \\
\hline GMT13-10-NC1 & 6-Jun-13 & 220 & 25.7 & 3.97 & 0.42 & 0.39 & 23.01 & 26.07 & 29.57 \\
\hline GMT7-15.NCl & 4-Jul-10 & 140 & 6.1 & 1.99 & $\mathrm{NaN}$ & $\mathrm{NaN}$ & $\mathrm{NaN}$ & 18.40 & 16.64 \\
\hline GMT7.15.NC2 & 4.Jul-10 & 170 & 13.8 & 3.18 & $\mathrm{NaN}$ & $\mathrm{NaN}$ & $\mathrm{NaN}$ & 23.61 & 25.42 \\
\hline GMT7-16:NCl & 11-Jul-10 & 120 & 4.5 & 2.80 & 0.70 & 0.16 & 17.26 & 22.19 & 23.04 \\
\hline
\end{tabular}




\begin{tabular}{|c|c|c|c|c|c|c|c|c|c|}
\hline GMT13-12-NC1 & 4.Jul-13 & 180 & 9.2 & $\mathrm{NaN}$ & $\mathrm{NaN}$ & $\mathrm{NaN}$ & $\mathrm{NaN}$ & $\mathrm{NaN}$ & $\mathrm{NaN}$ \\
\hline GMT13-12-NC2 & 4.Jul-13 & 200 & 15 & 2.37 & .0 .26 & 0.28 & 22.18 & 20.34 & 19.91 \\
\hline GMT13-13-NC1 & 18-Jul-13 & 110 & 1 & 2.95 & $\mathrm{NaN}$ & $\mathrm{NaN}$ & $\mathrm{NaN}$ & 22.77 & 24.01 \\
\hline GMT13-13-NC2 & 18.Jul-13 & 90 & 6.4 & 3.69 & $\mathrm{NaN}$ & $\mathrm{NaN}$ & $\mathrm{NaN}$ & 25.26 & 28.20 \\
\hline GMT7-18-NC1 & 1-Aug.10 & 240 & 16.3 & 2.56 & 0.11 & 0.12 & 20.29 & 21.20 & 21.36 \\
\hline GMT7-18-NC2 & 1.Aug-10 & 170 & 4.8 & 3.84 & $\mathrm{NaN}$ & $\mathrm{NaN}$ & $\mathrm{NaN}$ & 25.70 & 28.95 \\
\hline GMT7.18-NC3 & 1.Aug-10 & 200 & 15.9 & 3.96 & .0 .23 & 0.44 & 22.03 & 26.04 & 29.53 \\
\hline GMT7-19-NC1 & 15-Aug 10 & 190 & 16 & 3.62 & 0.21 & 0.12 & 19.77 & 25.05 & 27.85 \\
\hline GMT11-20-NC1 & 10-Aug 12 & 260 & 38 & 2.67 & 0.19 & 0.23 & 19.88 & 21.66 & 22.15 \\
\hline GMT13-15-NC1 & 15-Aug 13 & 230 & 19.7 & 3.32 & .0 .23 & 0.35 & 22.03 & 24.08 & 26.23 \\
\hline GMT13-15-NC2 & 15-Aug. 13 & 180 & 15.3 & $\mathrm{NaN}$ & $\mathrm{NaN}$ & $\mathrm{NaN}$ & $\mathrm{NaN}$ & $\mathrm{NaN}$ & $\mathrm{NaN}$ \\
\hline GMT13-15-NC3 & 15-Aug 13 & 190 & 12.3 & 2.82 & .0 .27 & .0 .59 & 22.24 & 22.27 & 23.17 \\
\hline GMT13-16-NC1 & 29-Aug. 13 & 180 & 9.5 & 3.13 & 0.30 & 0.53 & 22.39 & 23.43 & 25.12 \\
\hline GMT12-3.NC1 & 19.Sep-12 & 160 & 8.5 & 3.32 & $\mathrm{NaN}$ & $\mathrm{NaN}$ & $\mathrm{NaN}$ & 24.08 & 26.23 \\
\hline GMT12.3.NC2 & 19.Sep-12 & 200 & 15.9 & 2.41 & 0.25 & 0.18 & 19.57 & 20.52 & 20.23 \\
\hline GMT82-NC1 & 1 . Oct 10 & 190 & 9 & $\mathrm{NaN}$ & $\mathrm{NaN}$ & $\mathrm{NaN}$ & $\mathrm{NaN}$ & $\mathrm{NaN}$ & $\mathrm{NaN}$ \\
\hline GMT13-19-NC1 & $10.0 \mathrm{ct}-13$ & 210 & 13.6 & 3.25 & .0 .43 & 0.48 & 23.06 & 23.85 & 25.83 \\
\hline GMT84-NC1 & 15 - oct- 10 & 160 & 23.8 & $\mathrm{NaN}$ & $\mathrm{NaN}$ & $\mathrm{NaN}$ & $\mathrm{NaN}$ & $\mathrm{NaN}$ & $\mathrm{NaN}$ \\
\hline GMT13-20-NC1 & 24-Oct-13 & 140 & 5.6 & 3.23 & $\mathrm{NaN}$ & $\mathrm{NaN}$ & $\mathrm{NaN}$ & 23.78 & 25.71 \\
\hline GMT8-8NC1 & 12-Nov-10 & 120 & 7.8 & 2.32 & $\mathrm{NaN}$ & $\mathrm{NaN}$ & $\mathrm{NaN}$ & 20.10 & 19.51 \\
\hline GMT13-21-NC1 & 7-Nov-13 & 100 & 4.7 & 4.24 & $\mathrm{NaN}$ & $\mathrm{NaN}$ & $\mathrm{NaN}$ & 26.80 & 30.81 \\
\hline GMT8-14-NC1 & 24-Dec 10 & 220 & 13.3 & 2.96 & 0.40 & 0.21 & 22.90 & 22.81 & 24.08 \\
\hline GMT8-14NC2 & 24-Dec 10 & 250 & 24.5 & 2.74 & .0 .06 & 0.01 & 21.16 & 21.95 & 22.63 \\
\hline GMT8-15-NC1 & 31-Dec 10 & 230 & 21.3 & 3.93 & 0.21 & 0.26 & 21.93 & 25.96 & 29.38 \\
\hline GMT8-15-NC2 & 31-Dec 10 & 230 & 16.5 & 3.18 & 0.38 & 0.23 & 22.80 & 23.61 & 25.42 \\
\hline GMT10-15-NC1 & 28-Dec-11 & 240 & 29 & 2.67 & 0.54 & 0.32 & 23.62 & 21.66 & 22.15 \\
\hline GMT10-15-NC2 & 28-Dec-11 & 220 & 20.7 & 3.13 & 0.24 & 0.40 & 22.08 & 23.43 & 25.12 \\
\hline GMT10.15-NC3 & 28-Dec-11 & 210 & 17 & $\mathrm{NaN}$ & 0.20 & 0.34 & 19.82 & $\mathrm{NaN}$ & $\mathrm{NaN}$ \\
\hline GMT14-6-NC1 & 31-Dec-13 & 200 & 14.1 & 2.20 & -1.13 & 0.73 & 26.65 & 19.51 & 18.52 \\
\hline GMT14-6-NC2 & 31-Dec 13 & 180 & 10.2 & 2.68 & .0 .57 & 0.21 & 23.77 & 21.70 & 22.22 \\
\hline Sample & Date & Length $(\mu \mathrm{m})$ & Weight ( $(\mu \mathrm{g})$ & $\begin{array}{l}\text { Weighted } \mathrm{Mg} / \mathrm{Ca} \\
(\mathrm{mmol} / \mathrm{mol})\end{array}$ & $\begin{array}{c}\text { Measured } \delta 180 c \\
\text { (per mil VPDB) }\end{array}$ & $\begin{array}{c}\text { Measured } \delta 13 \mathrm{Cc} \\
\text { (per mil VPDB) }\end{array}$ & $\begin{array}{c}\text { Temperature }\left({ }^{\circ} \mathrm{C}\right) \\
\text { Spero et al., } 2003 \\
\text { (G. menardii) }\end{array}$ & $\begin{array}{l}\text { Temperature }\left({ }^{\circ} \mathrm{C}\right) \\
\text { Anand et al., } 2003\end{array}$ & $\begin{array}{c}\text { Temperature }\left({ }^{\circ} \mathrm{C}\right) \\
\text { Equation } 2 \text { (th is study) }\end{array}$ \\
\hline GMT6-17.C1 & 21-Jan-10 & 270 & 58 & 1.23 & $\mathrm{NaN}$ & $\mathrm{NaN}$ & $\mathrm{NaN}$ & $\mathrm{NaN}$ & 7.60 \\
\hline GMT6-17-C2 & 21-Jan-10 & 280 & 67 & 1.02 & 1.31 & 1.25 & 10.55 & 11.02 & 4.21 \\
\hline GMT8-17.C1 & 14-Jan-11 & 200 & 40 & 0.67 & 1.85 & 1.26 & 7.79 & 6.37 & 3.62 \\
\hline GMT8-17.C2 & 14-Jan-11 & 200 & 24 & 1.33 & 1.05 & 0.49 & 11.88 & 13.92 & 9.10 \\
\hline GMT10-19.C1 & 25-Jan- 12 & 200 & 36 & 1.69 & 0.79 & 0.69 & 13.22 & 16.55 & 13.53 \\
\hline GMT10-19.C2 & 25-Jan-12 & 260 & 65 & 1.78 & 1.06 & 1.07 & 11.83 & 17.14 & 14.52 \\
\hline GMT12-16-C1 & 12-Jan-13 & 240 & 51 & 1.12 & 1.81 & 1.42 & 7.99 & 11.97 & 5.81 \\
\hline GMT12-16C2 & 12-Jan-13 & 250 & 52 & 1.67 & 1.22 & 0.99 & 10.99 & 16.43 & 13.32 \\
\hline GMT14.7.C1 & 7.Jan-14 & 200 & 34 & 1.45 & 1.37 & 0.84 & 10.25 & 14.91 & 10.76 \\
\hline GMT14.7.C2 & 7.Jan-14 & 280 & 69 & 1.03 & 1.96 & 1.34 & 7.22 & 11.11 & 4.36 \\
\hline GMT6-18-C1 & 4Feb-10 & 220 & 37 & $\mathrm{NaN}$ & $\mathrm{NaN}$ & $\mathrm{NaN}$ & $\mathrm{NaN}$ & $\mathrm{NaN}$ & $\mathrm{NaN}$ \\
\hline GMT6-18-C2 & 4.Feb-10 & 240 & 55 & 1.01 & 1.15 & 0.96 & 11.34 & 10.90 & 4.01 \\
\hline GMT9.3.C1 & 25-Feb-11 & 300 & 85 & 1.52 & 1.11 & 0.88 & 11.57 & 15.39 & 11.57 \\
\hline GMT9.3.C2 & 25-Feb-11 & 260 & 69 & 1.02 & 1.29 & 0.94 & 10.66 & 11.00 & 4.17 \\
\hline GMT10-20C1 & 1-Feb-12 & 260 & 61 & 1.37 & 1.00 & 0.77 & 12.11 & 14.28 & 9.71 \\
\hline GMT10-20C2 & 1-Feb-12 & 250 & 66 & 1.01 & 0.92 & 0.91 & 12.52 & 10.88 & 3.98 \\
\hline GMT13-2.C1 & 17-Feb-13 & 220 & 53 & 1.28 & 2.17 & 1.88 & 6.11 & 13.49 & 8.37 \\
\hline GMT13-2.C2 & 17-Feb-13 & 230 & 59 & 2.35 & 1.16 & 0.90 & 11.30 & 20.25 & 19.76 \\
\hline GMT14-13-C1 & 18-Feb-14 & 210 & 37 & 1.81 & 1.54 & 0.78 & 9.37 & 17.33 & 14.84 \\
\hline GMT14.13.C2 & 18-Feb-14 & 220 & 40 & 1.92 & 1.58 & 0.87 & 9.15 & 17.99 & 15.96 \\
\hline GMT9.4.C1 & 7-Mar-11 & 240 & 64 & 1.03 & 1.49 & 1.12 & 9.63 & 11.09 & 4.32 \\
\hline GMT9.4.C2 & 7-Mar-11 & 240 & 67 & 1.09 & 1.51 & 1.30 & 9.49 & 11.69 & 5.34 \\
\hline GMT9.7.C1 & 28-Mar-11 & 260 & 60 & $\mathrm{NaN}$ & $\mathrm{NaN}$ & $\mathrm{NaN}$ & $\mathrm{NaN}$ & $\mathrm{NaN}$ & $\mathrm{NaN}$ \\
\hline GMT9.7.C2 & 28-Mar-11 & 240 & 59 & 1.32 & 2.35 & 1.45 & 5.22 & 13.82 & 8.93 \\
\hline GMT11-1-C1 & 30-Mar-12 & 250 & 66 & 1.05 & 1.62 & 1.10 & 8.93 & 11.24 & 4.59 \\
\hline GMT11-1-C2 & $30-\mathrm{Mar}-12$ & 280 & 83 & 1.76 & 1.28 & 1.07 & 10.69 & 17.06 & 14.38 \\
\hline GMT13.4.C1 & 14-Mar-13 & 250 & 68 & 1.46 & 1.40 & 1.01 & 10.07 & 14.92 & 10.79 \\
\hline GMT13.4.C2 & 14-Mar-13 & 260 & 60 & 1.04 & 1.54 & 1.13 & 9.34 & 11.17 & 4.46 \\
\hline GMT14.16C1 & 16-Mar -14 & 210 & 51 & 1.01 & 1.40 & 0.80 & 10.06 & 10.88 & 3.98 \\
\hline GMT14.16C2 & 16-Mar-14 & 220 & 32 & 1.64 & 1.38 & 0.71 & 10.18 & 16.28 & 13.07 \\
\hline GMT7.4.C1 & 17-Apr-10 & 220 & 55 & 1.30 & 1.07 & 0.71 & 11.76 & 13.66 & 8.66 \\
\hline
\end{tabular}




\begin{tabular}{|c|c|c|c|c|c|c|c|c|c|}
\hline GMT7 4.C2 & 17-Apr-10 & 230 & 64 & 1.30 & 1.57 & 1.19 & 9.23 & 13.63 & 8.60 \\
\hline GMT9-8.C1 & 4-Apr-11 & 300 & 86 & 1.65 & 1.86 & 1.45 & 7.73 & 16.33 & 13.15 \\
\hline GMT9.8.C2 & 4-Apr-11 & 280 & 95 & 1.53 & 2.16 & 1.50 & 6.17 & 15.47 & 11.71 \\
\hline GMT11-2-C1 & 6-Apr-12 & 240 & 79 & 0.95 & 1.18 & 1.07 & 11.19 & 10.24 & 2.89 \\
\hline GMT11-2.C2 & 6-Apr-12 & 240 & 56 & 1.26 & 1.42 & 1.01 & 9.97 & 13.34 & 8.12 \\
\hline GMT114C1 & 20-Apr-12 & 250 & 57 & 1.44 & 1.88 & 1.49 & 7.63 & 14.77 & 10.53 \\
\hline GMT114.C2 & 20-Apr-12 & 280 & 91 & 1.18 & 1.93 & 1.57 & 7.37 & 12.58 & 6.85 \\
\hline GMT13.6.C1 & 11-Apr-13 & 220 & 48 & 1.81 & 1.63 & 1.06 & 8.92 & 17.37 & 14.91 \\
\hline GMT13.6.C2 & 11-Apr-13 & 250 & 58 & $\mathrm{NaN}$ & $\mathrm{NaN}$ & $\mathrm{NaN}$ & $\mathrm{NaN}$ & $\mathrm{NaN}$ & $\mathrm{NaN}$ \\
\hline GMT10-3-NC1 & 18-Sep-11 & 310 & 94 & 2.12 & 1.85 & 1.85 & 7.76 & 19.12 & 17.86 \\
\hline GMT8.7.NC1 & 5-Nov-10 & 280 & 70 & 1.28 & 0.83 & 0.73 & 13.00 & 13.49 & 8.37 \\
\hline
\end{tabular}




\section{APPENDIX D: IMPACTS OF THE SALINITY EFFECT}

Calcification temperature is the primary control on $\mathrm{Mg} / \mathrm{Ca}$ in foraminiferal calcite; however, salinity has been shown to have a secondary influence on the $\mathrm{Mg} / \mathrm{Ca}$ of planktic foraminifera (Nürnberg et al., 1996; Lea et al., 1999; Kisakürek et al., 2008; Arbuszewski et al., 2010). Most studies have converged on an average of 3-5 \% increase in $\mathrm{Mg} / \mathrm{Ca}$ per salinity unit (Hönish et al., 2013; Gray et al., 2018) using Globigerinoides ruber (white), Orbulina universa and Globigerinoides sacculifer. Arbuszewski et al. (2010) showed a much larger salinity sensitivity (27 \%) in a global core-top study, but that study has since been shown to be inaccurate (Hönish et al., 2013; Khider et al., 2015). No studies have specifically addressed the influence of salinity on $\mathrm{Mg} / \mathrm{Ca}$ in the non-spinose planktic foraminifers like Globorotalia truncatulinoides. Nevertheless, I wanted to assess how varying the salinity might affect our downcore $\mathrm{Mg} / \mathrm{Ca}$-SST estimates from $\mathrm{G}$. truncatulinoides. To do this, I use a multivariate equation that Tierney et al., (2015) generated to solve for both temperature and salinity using paired $\mathrm{Mg} / \mathrm{Ca}$ and $\delta^{18} \mathrm{O}_{\mathrm{c}}$ in $\mathrm{G}$. ruber:

$$
\begin{gathered}
\ln \left(\frac{M g}{C a}\right)=0.084 * T+0.051 * S-2.54 \\
n=31, r^{2}=0.86, R M S E=0.12
\end{gathered}
$$

Since I did not have an independent proxy for salinity, I arbitrarily chose to apply a secular 5 practical salinity unit (PSU) increasing and decreasing salinity trend (from an average 36 PSU 
based on modern observations) over the past 150 years to determine how such a salinity change would change the $\mathrm{Mg} / \mathrm{Ca}-\mathrm{SST}$ estimates. In Figure 1 I compared temperature trends from a nonencrusted (NC) G. truncatulinoides Mg/Ca dataset from the Pigmy Basin in the northern Gulf of Mexico (nGoM). The secular warming trend is linear with respect to the change in salinity. The total range of salinity in the water column, based on 20 CTD casts 2008-2017, is 36.9-34.8 PSU, a change of \pm 2.1 PSU. That change is plotted in gray in Figure 1 and allows for a conservative look at the potential changes in water mass in the nGoM.

Equation 2 and Anand et al., (2003), from Appendix A, assume temperature trends of 5.4 ${ }^{\circ} \mathrm{C}$ and $3.2^{\circ} \mathrm{C}$, respectively. Both estimates are larger than the HadISST dataset $\left(0.5^{\circ} \mathrm{C}\right)$ in the nGoM and TEX 86 -SST $\left(1.1^{\circ} \mathrm{C}\right)$ and $\mathrm{Mg} / \mathrm{Ca}-\mathrm{SST}$ G. ruber $\left(1.4^{\circ} \mathrm{C}\right)$, from the same sediment trap samples. Assuming a linear trend in salinity, I can see the effect on $\mathrm{Mg} / \mathrm{Ca}-\mathrm{SST}$. When I use the multivariate equation with decreasing and increasing salinity through time I can use it to verify the Anand et al. (2003) equation in my publication as well as determine what types of temperature trends could evolve from the change in salinity. 


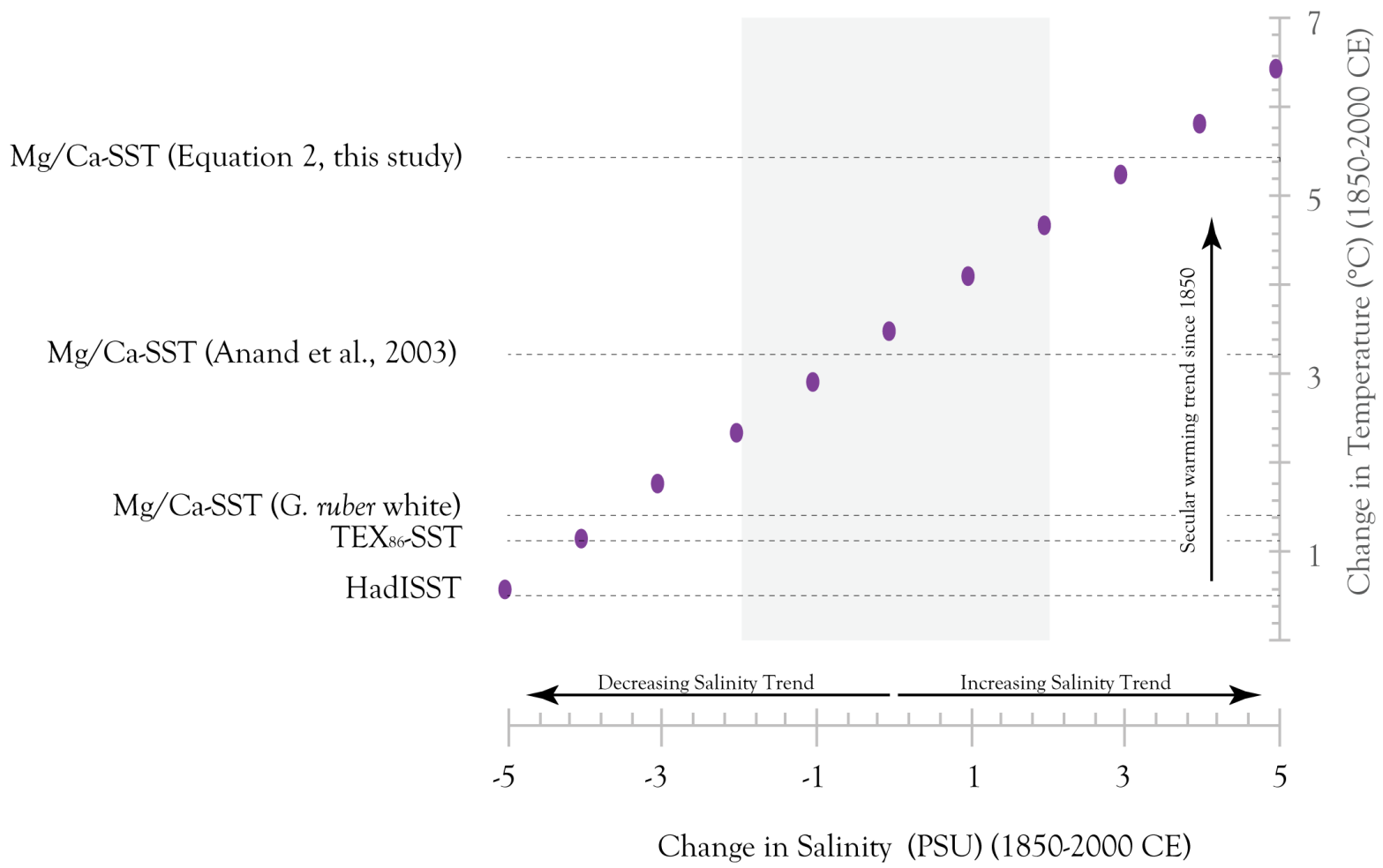

Figure 1. Non-encrusted G. truncatulinoides $\mathrm{Mg} / \mathrm{Ca}$ converted to temperature from Pigmy Basin box core (PBBC-1) in the northern GoM (from Spear et al., 2011). The change in salinity from 36 PSU is plotted on the y-axis and the change in $\mathrm{Mg} / \mathrm{Ca}$-SST on the y-axis. Also plotted in gray dashed lines are the temperatures trends mentioned in the manuscript. The gray box indicates the total range of salinity (36.9-34.8 PSU) from 20 CTD casts taken at the sediment trap site 20082017.

\section{References}


Arbuszewski, J., deMenocal, P., Kaplan, A., Farmer, E.C., 2010. On the fidelity of shell-derived $\delta^{18} \mathrm{O}$ seawater estimates. Earth Planet. Sci. Lett.300, 185-196. https://doi.org/10.1016/j.eps1.2010.10.035.

Gray, W.R., Weldeab, S., Lea, D.W., Rosenthal, Y., Gruber, N., Donner, B., Fischer, G., 2018. The effects of temperature, salinity, and the carbonate system in Globigerinoides ruber (white): A global sediment trap calibration. Earth Planet. Sci. Lett. 482, 607-620. https://doi.org/10.1016/j.epsl.2017.11.026

Hönisch, B., Allen, K.A., Lea, D.W., Spero, H.J., Eggins, S.M., Arbuszewski, J., deMeno-cal, P., Rosenthal, Y., Russell, A.D., Elderfield, H., 2013. The influence of salinity on Mg/Ca in planktic foraminifers - evidence from cultures, core-top sediments and complementary $\delta^{18} \mathrm{O}$. Geochim. Cosmochim. Acta121, 196-213.

https://doi.org/10.1016/j.gca.2013.07.028.

Khider, D., Huerta, G., Jackson, C., Stott, L.D., Emile-Geay, J., 2015. A Bayesian, multivariate calibration for Globigerinoides ruber Mg/Ca. Geochem. Geophys. Geosyst.16, 2916-2932. https://doi.org/10.1002/2015GC005844.

Kisakürek, B., Eisenhauer, A., Böhm, F., Garbe-Schönberg, D., Erez, J., 2008. Controls on shell $\mathrm{Mg} / \mathrm{Ca}$ and $\mathrm{Sr} / \mathrm{Ca}$ in cultured planktonic foraminiferan, Globigerinoides ruber (white). Earth Planet. Sci. Lett.273, 260-269. https://doi.org/10.1016/j.epsl.2008.06.026.

Lea, D.W., Mashiotta, T.A., Spero, H.J., 1999. Controls on magnesium and strontium uptake in 
planktonic foraminifera determined by live culturing. Geochim. Cos-mochim. Acta63, 2369-2379. https://doi.org/10.1016/S0016-7037(99)00197-0.

Nürnberg, D., Bijma, J., Hemleben, C., 1996. Assessing the reliability of magnesium in foraminiferal calcite as a proxy for water mass temperatures. Geochim. Cos-mochim. Acta60, 803-814. https://doi.org/10.1016/0016-7037(95)00446-7.

Spear, J. W., Poore, R. Z., and Quinn, T. M., 2011, Globorotalia truncatulinoides (dextral) Mg/Ca as a proxy for Gulf of Mexico winter mixed-layer temperature: Evidence from a sediment trap in the northern Gulf of Mexico: Marine Micropaleontology, v. 80, no. 3-4, p. 53-61.

Tierney, J. E., F. S. R. Pausata, and P. B. deMenocal (2016). Deglacial Indian monsoon failure and North Atlantic stadials linked by Indian Ocean surface cooling, Nature Geoscience, 9, 4650. doi: $10.1038 /$ ngeo2603. 